In cooperation with the Michigan Department of Environmental Quality and the Michigan Department of Natural Resources

\title{
A Regression Model for Computing Index Flows Describing the Median Flow for the Summer Month of Lowest Flow in Michigan
}

Scientific Investigations Report 2008-5096 



\section{A Regression Model for Computing Index Flows Describing the Median Flow for the Summer Month of Lowest Flow in Michigan}

By David A. Hamilton, Richard C. Sorrell, and David J. Holtschlag

In cooperation with the Michigan Department of Environmental Quality and the Michigan Department of Natural Resources

Scientific Investigations Report 2008-5096 


\section{U.S. Department of the Interior DIRK KEMPTHORNE, Secretary}

\section{U.S. Geological Survey \\ Mark D. Myers, Director}

U.S. Geological Survey, Reston, Virginia: 2008

For product and ordering information:

World Wide Web: http://www.usgs.gov/pubprod

Telephone: 1-888-ASK-USGS

For more information on the USGS--the Federal source for science about the Earth, its natural and living resources, natural hazards, and the environment:

World Wide Web: http://www.usgs.gov

Telephone: 1-888-ASK-USGS

Any use of trade, product, or firm names is for descriptive purposes only and does not imply endorsement by the U.S. Government.

Although this report is in the public domain, permission must be secured from the individual copyright owners to reproduce any copyrighted materials contained within this report.

Suggested citation:

Hamilton, D.A., Sorrell, R.C., and Holtschlag, D.J., 2008, A regression model for computing index flows describing the median flow for the summer month of lowest flow in Michigan: U.S. Geological Survey Scientific Investigations Report 2008-5096, 43 p. 


\section{Contents}

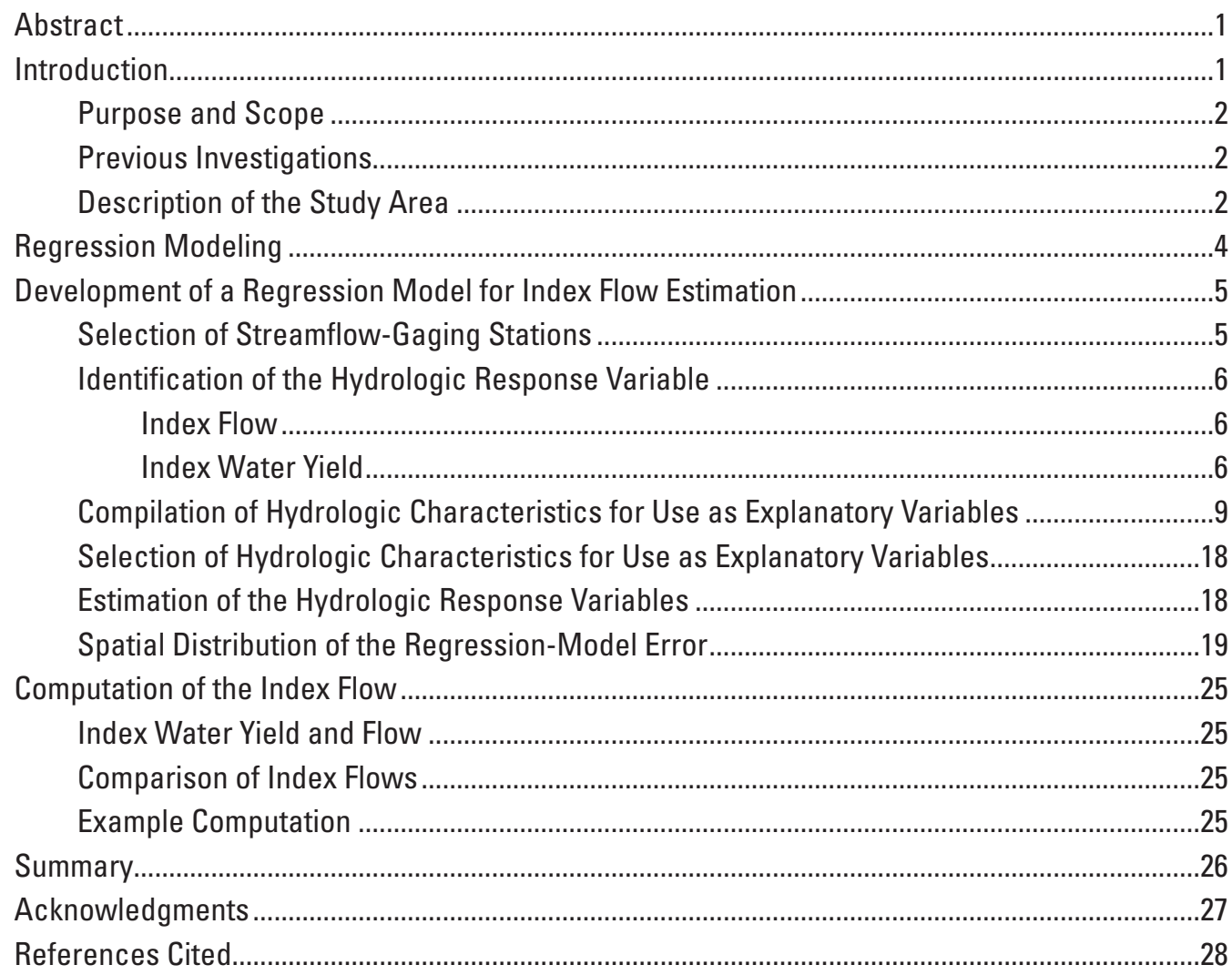

\section{Figures}

1-3. Maps showing:

1. Michigan's Upper and Lower Peninsulas and surrounding states

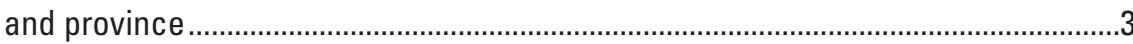

2. U.S. Geological Survey streamflow-gaging stations in Michigan's Upper Peninsula included in the analyses.

3. U.S. Geological Survey streamflow-gaging stations in Michigan's Lower Peninsula included in the analyses

4-6. Graphs showing:

4. Relation between estimates of index flow from gaging station records and drainage area

5. Empirical and fitted normal distributions for median-water-yield data from the month of lowest flow for selected streamflow-gaging stations in Michigan ........................................................................................................... 10

6. Distribution of estimated aquifer transmissivity classes in Michigan......................11

7-11. Maps showing:

7. Distribution of aquifer transmissivity classes in Michigan .....................................12

8. Distribution of forest cover in Michigan .................................................................14 
9. Distribution of hydrologic soil groups in Michigan

10. Distribution of normal annual precipitation in Michigan for 1971-2000.....

11. Distribution of normal annual snowfall depths in Michigan for 1971-2000 .............17

12-13. Graphs showing:

12. Relation between $R \hat{I} Y_{50}$ (the index of water yield estimated by regression) and $R I_{50}$ (the index of water yield computed on the basis of the streamflowgaging station records)

13. Distribution of explanatory variables selected for the regression model...............22

14. Map showing hydrologic subregions used in the analysis of the spatial distribution of regression-model error

15-16. Graphs showing:

15. Regional distribution of regression model errors for estimating median water yield during the summer month of minimum flow.

16. Relation between measured and computed index flows for selected streamflow gaging stations in Michigan

\section{Tables}

1. Lower triangular elements of the diagonally symmetric correlation matrix among candidate explanatory variables and the square root of median

water yield for the summer month of lowest flow in Michigan

2. Regression model parameters for estimating the hydrologic response variable ...........20

3. Cross-tabulation of land use-land cover areas with hydrologic soil groups for land areas within Michigan

4. Lower triangular elements of the diagonally symmetric correlation matrix among parameters of selected explanatory variables and the square root of median water yield for the summer month of lowest flow in Michigan.

5. The inverse of the $X^{\prime} X$ matrix needed to compute prediction limits

Appendix 1. Tables of streamflow-gaging station attributes, flow characteristics, and explanatory variables used in the development of the regression equation for estimating the index flow at ungaged streams in Michigan

1-1. Flow, yield, and record characteristics for streamflow-gaging stations used in the regression analysis

1-2. Values of selected explanatory variables used in the development of the regression equation for estimating the index flow

1-3. Cross-tabulation of cell counts and percentages for Michigan Resource Information System (MIRIS) 1978 land use-land cover and hydrologic soil groups in Michigan. 


\section{Conversion Factors and Abbreviations}

\begin{tabular}{|c|c|c|}
\hline Multiply & By & To obtain \\
\hline \multicolumn{3}{|c|}{ Length } \\
\hline inch (in.) & 2.54 & centimeter $(\mathrm{cm})$ \\
\hline foot (ft) & 0.3048 & meter (m) \\
\hline mile (mi) & 1.609 & kilometer $(\mathrm{km})$ \\
\hline meter (m) & 3.281 & foot $(\mathrm{ft})$ \\
\hline kilometer $(\mathrm{km})$ & 0.6214 & mile (mi) \\
\hline \multicolumn{3}{|c|}{ Area } \\
\hline square mile $\left(\mathrm{mi}^{2}\right)$ & 259.0 & hectare (ha) \\
\hline square mile $\left(\mathrm{mi}^{2}\right)$ & 2.590 & square kilometer $\left(\mathrm{km}^{2}\right)$ \\
\hline \multicolumn{3}{|c|}{ Flow rate } \\
\hline cubic foot per second (ft³/s) & 0.02832 & cubic meter per second $\left(\mathrm{m}^{3} / \mathrm{s}\right)$ \\
\hline $\begin{array}{l}\text { cubic foot per second per square } \\
\text { mile }\left[\left(\mathrm{ft}^{3} / \mathrm{s}\right) / \mathrm{mi}^{2}\right]\end{array}$ & 0.01093 & $\begin{array}{l}\text { cubic meter per second per square } \\
\text { kilometer }\left[\left(\mathrm{m}^{3} / \mathrm{s}\right) / \mathrm{km}^{2}\right]\end{array}$ \\
\hline gallon per day (gal/d) & 3.785 & liters per day (liters per day) \\
\hline inch per year (in/yr) & 2.54 & centimeter per year (cm/yr) \\
\hline \multicolumn{3}{|c|}{ Transmissivity* } \\
\hline foot squared per day $\left(\mathrm{ft}^{2} / \mathrm{d}\right)$ & 0.09290 & meter squared per day $\left(\mathrm{m}^{2} / \mathrm{d}\right)$ \\
\hline
\end{tabular}

Temperature in degrees Fahrenheit $\left({ }^{\circ} \mathrm{F}\right)$ may be converted to degrees Celsius $\left({ }^{\circ} \mathrm{C}\right)$ as follows:

${ }^{\circ} \mathrm{C}=\left({ }^{\circ} \mathrm{F}-32\right) / 1.8$

Vertical coordinate information is referenced to the North American Vertical Datum of 1988 (NAVD 88).

Horizontal coordinate information is referenced to the North American Datum of 1983 (NAD 83).

Altitude, as used in this report, refers to distance above the vertical datum.

*Transmissivity: The standard unit for transmissivity is cubic foot per day per square foot times foot of aquifer thickness $\left[\left(\mathrm{ft}^{3} / \mathrm{d}\right) / \mathrm{ft}^{2}\right] \mathrm{ft}$. In this report, the mathematically reduced form, foot squared per day $\left(\mathrm{ft}^{2} / \mathrm{d}\right)$, is used for convenience. 


\section{List of Symbols}

\begin{tabular}{|c|c|}
\hline Symbol & Name \\
\hline$y$ & A column vector containing the hydrologic response variable \\
\hline$X$ & $\begin{array}{l}\text { The "design matrix," which, in general, is composed of } p \text { columns of basin } \\
\text { and climatic characteristics augmented with a leading column of ones that } \\
\text { serve as explanatory variables to estimate the hydrologic response }\end{array}$ \\
\hline$\beta$ & $\begin{array}{l}\text { A column vector of parameters, } \beta_{0}, \beta_{1}, \ldots, \beta_{p} \text {, that relate the explanatory } \\
\text { variables to the hydrologic response variable }\end{array}$ \\
\hline$\beta_{\text {ols }}$ & $\begin{array}{l}\text { The ordinary least-square estimator of } \beta \text { is denoted and computed as } \\
\beta_{\text {ols }}=\left(X^{\prime} \cdot X\right)^{-1} \cdot X^{\prime} \cdot y \text {, where the prime symbol implies a matrix transpose } \\
\text { and the }-1 \text { power implies a matrix inverse operation }\end{array}$ \\
\hline$\varepsilon$ & $\begin{array}{l}\text { A vector of residuals that is assumed to be normally distributed and inde- } \\
\text { pendent with mean zero and constant variance } \sigma^{2} \text {, commonly written } \varepsilon \sim \\
\operatorname{NI}\left(0, \sigma^{2}\right) \text {. }\end{array}$ \\
\hline $\operatorname{Cov}(\varepsilon, X)$ & $\begin{array}{l}\text { The covariance matrix between the residual vector, } \varepsilon \text {, and the explanatory } \\
\text { variables contained in the design matrix, } \mathrm{X}\end{array}$ \\
\hline $\begin{array}{l}L P L_{\alpha / 2}, \\
U P L_{1-\alpha / 2}\end{array}$ & $\begin{array}{l}\text { The lower prediction limit and the upper prediction limit, respectively } \\
\text { centered about the regression estimate of the hydrologic response, } \hat{y}=x_{0} \text {. } \\
\beta_{\text {ols }} \text {. The interval }\left[L P L_{\alpha / 2}, U P L_{1-\alpha / 2}\right] \text { is likely to contain the true hydrologic } \\
\text { response, } y_{0} \text {, with a probability of } 1-\alpha\end{array}$ \\
\hline$x_{0}$ & $\begin{array}{l}\text { A row vector containing the basin and climatic characteristics at a specific } \\
\text { site, augmented with a leading one, that serves as the explanatory variables } \\
\text { to estimate the hydrologic response at that site }\end{array}$ \\
\hline$\alpha$ & $\begin{array}{l}\text { The specified alpha level for the confidence interval. For example, if alpha } \\
\text { was specified as } 0.2 \text {, there would be a } 10 \text {-percent chance that the hydro- } \\
\text { logic response would be less than } L P L_{\alpha / 2} \text { and a } 10 \text {-percent chance that it } \\
\text { would be greater than } U P L_{1-\alpha / 2} \text {, providing a total probability of } 20 \text { percent } \\
\text { that the true hydrologic response would be outside the prediction interval. }\end{array}$ \\
\hline$t_{n-p-1,1-\alpha / 2}$ & $\begin{array}{l}\text { The ordinate from the Student's ' } t \text { ' probability distribution for a specified } \\
\text { degrees of freedom equal to the number of observations }(n) \text {, minus the } \\
\text { number of estimated parameter for explanatory variables }(p) \text {, minus one for } \\
\text { the intercept. }\end{array}$ \\
\hline$s^{2}$ & The sample estimate of the population error variance $\sigma^{2}$ \\
\hline$S S_{T}$ & $\begin{array}{l}\text { The total sum of squares, computed as }(y-\bar{y})^{\prime}(y-\bar{y}) \text {, where } \bar{y} \text { is the sample } \\
\text { mean }\end{array}$ \\
\hline$S S_{E}$ & The sum of squared errors, computed as $(y-\hat{y})^{\prime}(y-\hat{y})=\varepsilon^{\prime} \varepsilon$ \\
\hline$d f_{E}$ & The degrees of freedom in the error term, computed as $n-p-1$ \\
\hline$M S_{E}$ & The mean square error, computed as $s^{2}=S S_{E} / d f_{E}$ \\
\hline$R M S_{E}$ & The square root of the mean square error \\
\hline$R_{p}^{2}$ & The Pearson multiple coefficient of determination, computed as $1-S S_{E} / S S_{T}$ \\
\hline$R_{\text {Adj }}^{2}$ & $\begin{array}{l}\text { The Pearson multiple coefficient of determination adjusted for the number of } \\
\text { estimated parameters }\end{array}$ \\
\hline
\end{tabular}




\begin{tabular}{|c|c|}
\hline Symbol & Name \\
\hline$r_{P}$ & $\begin{array}{l}\text { The Pearson product moment correlation coefficient, which the square root of } \\
R_{p}^{2}\end{array}$ \\
\hline$r_{S}$ & $\begin{array}{l}\text { The Spearman correlation coefficient, which is equal to the Pearson's cor- } \\
\text { relation coefficient if it were computed on the ranks of the data }\end{array}$ \\
\hline$R_{S}^{2}$ & $\begin{array}{l}\text { The Spearman coefficient of determination, which is the square of the Spear- } \\
\text { man correlation coefficient }\end{array}$ \\
\hline $\operatorname{cov}\left(\beta_{o l s}\right)_{i, j}$ & The covariance matrix among ordinary least-square parameter estimates \\
\hline $\operatorname{cor}\left(\beta_{\text {ols }}\right)_{i, j}$ & The correlation matrix, computed as $\operatorname{cov}\left(\beta_{\text {ols }}\right)_{i, j} / \sqrt{\operatorname{cov}\left(\beta_{\text {ols }}\right)_{i, i} \cdot \operatorname{cov}\left(\beta_{\text {ols }}\right)_{j, j}}$ \\
\hline
\end{tabular}





\title{
A Regression Model for Computing Index Flows Describing the Median Flow for the Summer Month of Lowest Flow in Michigan
}

\author{
By David A. Hamilton', Richard C. Sorrell', and David J. Holtschlag²
}

\section{Abstract}

In 2006, Michigan enacted laws to prevent new largecapacity withdrawals from decreasing flows to the extent that they would functionally impair a stream's ability to support characteristic fish populations. The median streamflow for the summer month of lowest flow was specified by state decision makers as the index flow on which likely impacts of withdrawals would be assessed. At sites near long-term streamflow-gaging stations, analysis of streamflow records during July, August, and September was used to determine the index flow. At ungaged sites, an alternate method for computing the index flow was needed. This report documents the development of a method for computing index flows at ungaged stream sites in Michigan. The method is based on a regression model that computes the index water yield, which is the index flow divided by the drainage area. To develop the regression model, index flows were determined on the basis of daily flows measured during July, August, and September at 147 streamflow-gaging stations having 10 or more years of record (considered long-term stations) in Michigan. The corresponding index water yields were statistically related to climatic and basin characteristics upstream from the stations in the regression model. Climatic and basin characteristics selected as explanatory variables in the regression model include two aquifer-transmissivity and hydrologic-soil groups, forest land cover, and normal annual precipitation. Regressionmodel estimates of water yield explain about 70.8 percent of the variability in index water yields indicated by streamflowgaging station records. Index flows computed on the basis of regression-model estimates of water yield and corresponding drainage areas explain about 94.0 percent of the variability in index flows indicated by streamflow-gaging station records. No regional bias was detected in the regression-based estimates of water yield within seven hydrologic subregions spanning Michigan. Thus, the single regression model developed in this report can be used to produce unbiased estimates of index water yield and flow statewide. In addition, a technique is presented for computing prediction intervals about the index flow estimates.

\section{Introduction}

The Michigan Legislature (2006) passed Public Act 33 in 2006 (PA33-2006); it and related laws are the first state laws to regulate water withdrawals. The legislation seeks to prevent any new or increased large-capacity withdrawal (generally referring to withdrawals that average more than 100,000 gallons of water per day $\left(0.1547 \mathrm{ft}^{3} / \mathrm{s}\right)$ in any consecutive 30 -day period) from causing an adverse resource impact. This impact is defined as decreasing the flow of a stream by part of the index flow such that the stream's ability to support characteristic fish populations is functionally impaired. PA33-2006 further defines index flow as the 50 percent exceedance (median) flow for the lowest flow month of the flow regime (year), as determined over the period of record or extrapolated from analyses of the U.S. Geological Survey (USGS) streamflowgaging-station records in Michigan.

In this report, the index flow is characterized as the median flow during the lowest flow in July, August, and September. The lowest monthly median summer flow was calculated by ranking the daily average flows at each USGS streamflow-gaging station (station) for the period of record, grouped by month. The median exceedance flow for each month was determined, and the lowest monthly value in the summer was selected as the index flow for each station. Summer is the time of greatest stress on the ecosystem from low flows and high temperatures.

Multiple linear regression models (Draper and Smith, 1966) are commonly used to transfer streamflow information from gaged to ungaged sites. The regression model includes an equation for estimating or predicting the index water yield, computed as the index flow divided by the drainage area

\footnotetext{
${ }^{1}$ Michigan Department of Environmental Quality.

${ }^{2}$ U.S. Geological Survey.
} 
contributing to flow, using basin and climatic characteristics as explanatory variables. In this report, "estimation" refers to the process of computing the square root of water yield or the corresponding index flow for a gaged site that was used in model development, whereas "prediction" refers to the process of computing the square root of water yield or the corresponding index flow for an ungaged site. Unless ambiguity would result, the term "computation" is used when the distinction between estimation and prediction is unimportant.

In addition to an equation for predicting the hydrologic response, regression models provide a probability model that describes the uncertainties of predicted responses. This uncertainty is sometimes expressed as a range of responses with a specified probability that is likely to contain the true hydrologic response at a particular stream site. The lower limit of this range can be used to help avoid overestimating a response, such as the index flow.

\section{Purpose and Scope}

This report documents the development of a multiple linear regression model for predicting the expected magnitude and uncertainty of the index water yield. The index water yield is the water yield associated with the index flow, which is the median flow for the month of lowest summer streamflow in Michigan. For ungaged sites, the predicted index water yield can be multiplied by the corresponding drainage area upstream from the site to compute the index flow. In addition to the expected magnitude of the index flow, the uncertainty characterized by the regression model provides a basis for computing a range of flows within which the true index flow is likely to occur. An example computation is given to illustrate application of the regression model for predicting water yield and computing magnitude and uncertainty of the index flow. The regression model is applicable to Michigan streams where index flows are not significantly affected by existing water withdrawals, diversions, or augmentations.

\section{Previous Investigations}

Knutilla (1967) and Holtschlag and Croskey (1984) developed statistical models for predicting a variety of low-, average-, and peak-flow characteristics for Michigan streams. Neff and others (2005) developed multiple regression equations for predicting base flow throughout the Great Lakes.
None of these studies, however, resulted in a method for estimating the median streamflow during the summer month of lowest flow in Michigan. Longer periods of record and additional streamflow-gaging sites, combined with improved methods for determining basin and climatic characteristics, created an opportunity to improve estimation of streamflow characteristics in Michigan and support implementation of the 2006 water-withdrawal legislation.

\section{Description of the Study Area}

Michigan is in the eastern north-central part of the United States and is surrounded by four of the five Great Lakes (fig. 1). Ontario, Canada lies to the north and east of Michigan. To the west and south, border states are Wisconsin, Indiana, and Ohio. Michigan is the $10^{\text {th }}$ largest state in the Union with a total land area of $58,110 \mathrm{mi}^{2}, 38,575 \mathrm{mi}^{2}$ of Great Lakes waters, and 1,305 $\mathrm{mi}^{2}$ of inland waters (Michigan Library, 2006). According to the U.S. Census Bureau (2007), the population of Michigan in 2006 was estimated to be 10,095,643.

Michigan has a humid continental climate in which the average precipitation (rainfall plus water-equivalent snowfall depths) varies from about 28 to $38 \mathrm{in} / \mathrm{yr}$. December through March tend to have slightly less precipitation, whereas July through September tend to have slighter more precipitation, than is typical for the rest of the year. Greater evapotranspiration during the summer, however, generally causes summer streamflows to be lower than those at other times of the year.

Michigan consists of two peninsulas separated by the Straits of Mackinac, a body of water that connects Lake Michigan with Lake Huron (fig. 1). The straits are spanned by the Mackinac Bridge, where the northern tip of the Lower Peninsula is within about $5 \mathrm{mi}$ of the southern coast of the eastern Upper Peninsula. The Upper Peninsula is heavily forested and somewhat mountainous in the west. Bedrock is at or near the surface in much of the Upper Peninsula.

The Lower Peninsula is covered by a thick layer of glacial drift. The northern part is characterized by sandy material and is heavily forested. Trout streams, sustained by plentiful base flow, are common in that area. Much of the southeastern part of the Lower Peninsula is flat lakebed plains that are extensively agricultural or urban; base flow is meager. The southwestern part of the Lower Peninsula has a wide mixture of landforms, soil types, land uses, and stream types. 

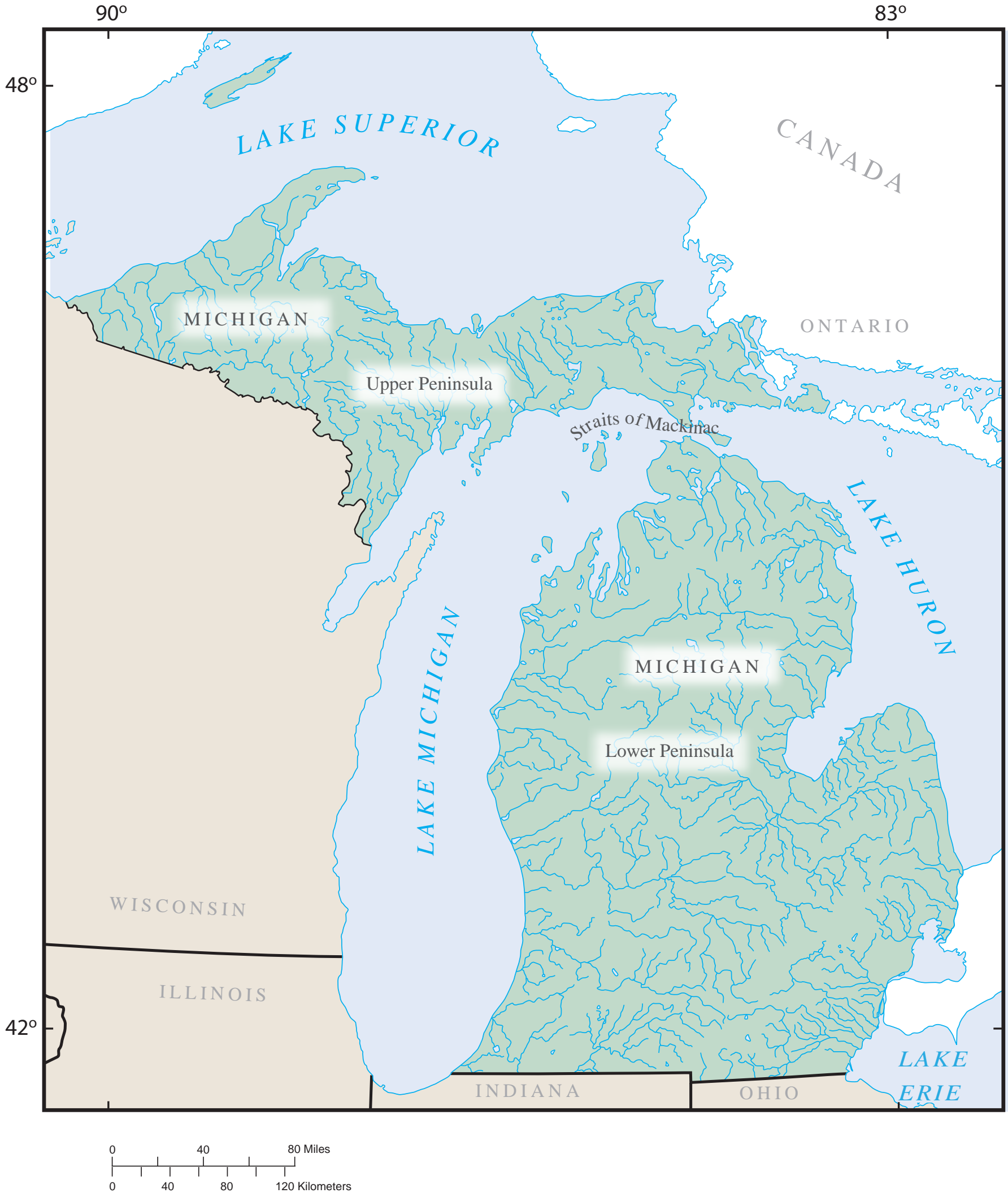

Figure 1. Michigan's Upper And Lower Peninsulas and surrounding states and province. 


\section{Regression Modeling}

A multiple linear regression model was developed to predict index water yield. The model consists of a linear equation that is a function of selected hydrologic characteristics and model parameters estimated from index flow divided by drainage areas at gaged sites. This equation, plus the probability model underlying the error distribution, form the regression model. The following paragraphs describe the mathematical procedures used to estimate the model parameters from available data and assumptions underlying the probability model. Techniques are described for using the model uncertainty and site-specific climatic and basin characteristics to bound model predictions with a specified level of certainty.

The general form of a multiple linear regression equation is

$$
y=X \cdot \beta+\varepsilon
$$

where

$y$ is a column vector containing the hydrologic response variable;

$X$ is referred to as the "design matrix," which, in general, is composed of $p$ columns of basin and climatic characteristics augmented with a leading column of 1 's that serve as explanatory variables to estimate the hydrologic response;

$\beta$ is a column vector of parameters, $\beta_{0}, \beta_{1}, \ldots, \beta_{p}$, that relate the explanatory variables to the hydrologic response variable; the ordinary least-square estimator of $\beta$ is denoted $\beta_{\text {ols }}$ and computed as $\beta_{\text {ols }}=\left(X^{\prime} \cdot X\right)^{-1}$ $\cdot X^{\prime} \cdot y$, where the prime symbol implies a matrix transpose and the -1 power implies a matrix inverse operation;

$\varepsilon$ is a vector of residuals that is assumed to be normally distributed and independent with mean zero and constant variance $\sigma^{2}$, commonly written $\varepsilon \sim N I\left(0, \sigma^{2}\right)$. In addition, it is assumed in the regression model that the covariance between $\varepsilon$ and $\mathrm{X}, \operatorname{Cov}(\varepsilon, X)$, equals zero.

Along with the predicted value itself, the distributional characteristics of the regression model error and the hydrologic characteristics at the site of interest are a basis for assessing the uncertainty of the predicted value. Let $\left[L P L_{\alpha / 2}, U P L_{1-\alpha / 2}\right]$ be a prediction interval between the lower prediction limit $L P L_{\alpha / 2}$ and the upper prediction limit $U P L_{1-\alpha / 2}$ centered about the regression estimate that is likely to contain the hydrologic response, $y_{0}$, with a probability of $1-\alpha$. For example, if $\alpha$ was specified as 0.2 , there would be a 10 -percent chance that the hydrologic response would be less than $L P L_{\alpha 2}$ and a 10-percent chance that it would be greater than $U P L_{1-\alpha / 2}$, providing a total probability of 20 percent that the true hydrologic response would be outside the prediction interval.

Computationally,

$$
\left[L P L_{\alpha / 2}, U P L_{1-\alpha / 2}\right]=x_{0} \cdot \beta_{o l s} \pm t_{n-p-1,1-\alpha / 2} \sqrt{s^{2}\left(1+x_{0}\left(X^{\prime} X\right)^{-1} x_{0}^{\prime}\right)}
$$

where $x_{0}$ is a row vector of corresponding basin characteristics at the site of interest augmented by a leading $1,\left(X^{\prime} X\right)^{-1}$ is a function of the design matrix used to estimate the model parameters, $s^{2}=\varepsilon^{\prime} \cdot \varepsilon /(n-p-1)$ and $t_{n-p-1, \alpha / 2}$ is the inverse of Student's $t$ cumulative distribution function with $n-p-1$ degrees of freedom at the specified alpha level divided by 2 .

The assumption that the regression residuals are normally distributed is often difficult to satisfy with water yield or flow values. In particular, the density function of the normal distribution is symmetrical, whereas water yield and flow data tend to be positively skewed because these variables are bounded by zero on the left and unbounded on the right side of the distribution. Logarithmic and square-root transformations are commonly applied to water yield and flow values to produce a hydrologic response variable for which model residuals are likely to be normally distributed. Unlike the logarithmic transformation, the square-root transformation does not eliminate observations that have zero values.

As a convenience to the interested reader, the following key statistics are defined. The total sum of squares is $S S_{T}=(y-\bar{y})^{\prime}(y-\bar{y})$, where $\bar{y}$ is the mean of the hydrologic response variable, the sum of squared errors is $S S_{E}=(y-\hat{y})^{\prime}(y-\hat{y}) \varepsilon^{\prime} \cdot \varepsilon$, and the model sum of squares is $S S_{M}=$ $S S_{T}-S S_{E}$. The mean square total is $M S_{T}=S S_{T} /(n-1)$. Degrees of freedom for the error is $d f_{E}=n-p-1$, which subtracts the number of model explanatory variables, $p$, plus 1 for the intercept term, to describe the effective number of observations associated with the model error. The mean square error is $M S_{E} \equiv S^{2}=S S_{E} / d f_{E}$ and the model mean square is $M S_{M}=S S_{M} / p$. The root mean square error is the square root of the mean square error, $R M S_{E}=\sqrt{M S_{E}}$. In addition, an $F$ statistic, computed by dividing the $M S_{M}$ by the $M S_{E}$, characterizes the overall statistical significance of the model. On the basis of the $F$ probability distribution, a probability value ( $p$-value) is computed with the $F$ statistic, as well as the degrees of freedom in the model and error components, to assess the likelihood that the null hypothesis that all model parameters are zero is true. A small $p$-value, commonly (but not necessarily) less than 0.05 , is used to reject the null hypothesis, thereby accepting the alternative hypothesis that, overall, the regression model is statistically significant.

The Pearson multiple coefficient of determination, here denoted as $R_{p}^{2}$, describes the fraction of the variability of $y$ described by $\hat{y}$ where $R_{p}^{2}=1-S S_{E} / S S_{T} \cdot R_{p}^{2}$ is equal to the squared Pearson's product moment correlation coefficient between hydrologic response variables computed on the basis of streamflow-gaging station records and values estimated by the regression equation, $r_{p}(y, \hat{y})$, where

$$
r_{P}(y, \hat{y})=\frac{\sum_{i=1}^{n}\left(y_{i}-\bar{y}\right)\left(\hat{y}_{i}-\overline{\hat{y}}\right)}{\sqrt{\sum_{i=1}^{n}\left(y_{i}-\bar{y}\right)^{2}} \cdot \sqrt{\sum_{i=1}^{n}\left(\hat{y}_{i}-\bar{y}\right)^{2}}}
$$


Indicators of estimation accuracy, such as $R_{p}^{2}$ and $R M S_{E}$, reflect the model fit to the dataset used in development of the regression model. These indicators tend to show model improvement with increasing numbers of explanatory variables because the model is increasing fit to the specific characteristics of the available observations. Prediction accuracy, which is associated with the accuracy of predicting the hydrologic response from a basin not used in model development, is more difficult to quantify with small datasets. Prediction accuracy, however, improves with the addition of explanatory variables only up to a point. Beyond this point, prediction accuracy may decrease with the further addition of explanatory variables because a model that too closely fits the specific characteristics of available observations may not generalize well.

To lessen the inflation of the model fit sometimes indicated by the $R_{p}^{2}$ value, the adjusted coefficient of determination, $R_{a d j}^{2}=1-\left(S S_{E} / n-p-1\right) /\left(S S_{T} /(n-1)\right)$, accounts for the number of parameters in the model. Spearman's correlation coefficient is a more robust measure of association than Pearson's correlation coefficient when the data distributions are skewed. The Spearman's correlation coefficient is computed similarly to Pearson's correlation coefficient except that the original data are replaced by their ranks, $r_{s}(y, \hat{y})=r_{p}(\operatorname{rank}(y)$, $\operatorname{rank}(\hat{y}))$, where the rank of the smallest value in the set is 1 and the rank of the largest value is $n$. Finally, Spearman's coefficient of determination, symbolized as $R_{S}^{2}$, is the square of Spearman's correlation coefficient.

Like the response estimates, estimated parameters $\beta_{\text {ols }}$ associated with the individual explanatory variables are uncertain. As the sample size (n) becomes large, estimated parameters are unbiased and normally distributed about their true values, assuming that $\varepsilon \sim N I\left(0, \sigma^{2}\right)$. The covariance of the parameter estimates, $\operatorname{cov}\left(\beta_{\text {ols }}\right)$ is equal to $\sigma^{2}\left(X^{\prime} \cdot X\right)^{-1}$, which is commonly written $\beta_{\text {ols }}^{\text {ols }} \sim N_{p+1}$ ( $\beta$, $\left.\operatorname{cov}\left(\beta_{\text {ols }}\right)\right)$. Diagonal elements of the covariance matrix describe the variance of the corresponding estimated parameters; off-diagonal elements describe the covariance among parameters. A large covariance among parameters indicates a coupling between one or more parameter estimates because of an approximate linear dependency among explanatory variables. Such a coupling complicates interpretation of parameter magnitudes associated with specific explanatory variables. The magnitude of parameter covariances is commonly evaluated on the basis of their correlations, computed as $\operatorname{cor}\left(\beta_{\text {ols }}\right)_{\mathrm{i}, \mathrm{j}}=\operatorname{cov}\left(\beta_{\text {ols }}\right)_{\mathrm{i}, \mathrm{j}} / \sqrt{\operatorname{cov}\left(\beta_{\text {ols }}\right)_{i, i} \cdot \operatorname{cov}\left(\beta_{\text {ols }}\right)_{j, j}}$. If the magnitudes of these correlations $\left|\operatorname{cor}\left(\beta_{o l s}\right)_{i, j}\right|$ exceed 0.95 (Poeter and others, 2005), the independence of the paired parameter estimates is uncertain.

A $t$ statistic computed from the data can be used to assess the significance of individual parameters as $t=\left(\beta_{\text {ols }}\right)_{\mathrm{i}, \mathrm{j}} / \sqrt{\operatorname{cov}\left(\beta_{\text {ols }}\right)_{i, i}}$. This $t$ statistic is used to compute the probability that the null hypothesis, $\beta_{1}=0$, is true. If this computed $p$-value is small, say less than 0.05 , the null hypothesis is commonly rejected, and the alternative hypothesis that $\beta_{1}=\beta_{\text {ols,i }}$ is effectively accepted. Rejecting the null hypothesis implies, that the parameter $\beta_{o l s, i}$ and corresponding explanatory variable are needed in the regression model.

\section{Development of a Regression Model for Index Flow Estimation}

Regression models are a statistical means of transferring flow information obtained at streamflow-gaging stations to ungaged sites in the same hydrologic region. The process of transferring flow information from gaged to ungaged basins is commonly referred to as "flow regionalization." The transfer is facilitated by identifying climatic and basin (hydrologic) characteristics in the gaged basins that are statistically related to the flow statistics computed from gaging-station records. Once this statistical relation is identified and regression parameters in the model equation are estimated, only the selected climatic and basin characteristics upstream from the ungaged site are needed to estimate the flow statistic for that location by use of the regression equation.

The regression model includes this equation and a set of assumptions pertaining to the model errors, which are the discrepancies between estimates of the flow statistics computed from gaging-station records and estimates computed by use of the regression model. It is often necessary to transform the streamflow statistics being estimated to satisfy assumptions associated with the model error. In regional flow analysis, a square-root or logarithmic transformation of the streamflow statistics is commonly applied prior to estimating regressionmodel parameters. The inverse transform is commonly applied to regression estimates to compute the flow statistics of interest. The spatial distribution of model error is investigated to assess whether any bias occurs among the hydrologic subregions forming the region. If no subregional bias is detected, the regression model is considered appropriate for estimating the flow characteristic of interest throughout the region. The regression model error characteristics also are a basis for computing an interval about the regression estimate in which the true, but unknown, value of the streamflow statistic is likely to occur.

\section{Selection of Streamflow-Gaging Stations}

Development of the regression model for regional flow characterization includes selection of streamflow-gaging stations where (1) no trends occur in the mean and variance of flow, (2) the period of record is sufficiently long to accurately characterize flow conditions of interest through statistical analysis of station records, (3) flow characteristics of interest are not substantially affected by water withdrawals, diversions, or regulation, and (4) streamflow represents the natural hydrologic response to climatic conditions and basin characteristics that are typical of the area. 
Streamflow data from the USGS network of continuousrecord streamflow-gaging stations operated in Michigan through water year 2005 were used for this analysis. A water year is the 12-month period from October 1 to September 30 and is identified by the calendar year in which it ends. Stations were selected for the regression analysis with respect to the following criteria:

1. A minimum of 10 years of continuous-record data was required to reduce the temporal sampling variability of the flow statistic.

2. Estimates of daily flow were not thought to be appreciably affected by water withdrawal, diversion, or augmentation.

3. Effects of regulation, either from natural storage in lakes or retention in regulated surface-water bodies, were not thought to substantially mask the hydrologic response from precipitation.

From these evaluations, 147 streamflow-gaging stations were selected for inclusion in the analyses (figs. 2 and 3). Among selected stations, the average length of record was 40.2 years, and the range was from 11 to 91 years. The first water year of record used in the analysis was 1901, and 88 stations included data from water year 2005.

\section{Identification of the Hydrologic Response Variable}

The regression equation described in this report is a basis for computing an estimate of the index flow, which is defined as the median streamflow for the summer month of lowest flow in Michigan. The statistical distribution of index flows, however, is not consistent with assumptions underlying the regression model. To find a metric of index flow that is consistent with these assumptions and one in which climatic and basin characteristics physically associated with the streamflow response are more readily identified, mathematical transformations of index flow values were investigated. As a result, the response variable used in the regression equation was formed as the square root of the quotient of index flow divided by the drainage area of its associated basin. In this report, the response variable is referred to as the "hydrologic response variable.” The inverse transformation is applied to the regression estimates of the hydrologic response to compute index flows.

\section{Index Flow}

In accordance with PA33-2006, the median flow during the lowest summer flow month was the index flow and is represented symbolically as $I Q_{50}$. A statistic was calculated to estimate $I Q_{50}$ by ranking the daily mean flows measured at each selected gaging station by month for the entire period of record available and selecting the 50th percentile. The median flow for each summer month (July, August, and September) was determined, and the summer month with the lowest median flow was used to estimate $I Q_{50}$ at that gaging station. To distinguish the true index flow $I Q_{50}$ from the value of the flow response computed by use of the finite period of gagingstation record, the gaging station statistic is symbolized as $\tilde{I} Q_{50}$. The value of $\tilde{I} Q_{50}$ is assumed to converge to $I Q_{50}$ as the length of gaged record increases. This assumption requires that there is no trend in the streamflow data (the expected value of $I Q_{50}$ does not vary with time) and that $\tilde{I} Q_{50}$ is an unbiased estimator of $I Q_{50}$. No trends were detected in streamflow data at the selected stations.

For the 147 stations selected for the analysis, the lowest median flow occurred in July at 5 stations, in August at 92 stations, and in September at 50 stations. The index flow ranged from zero at stations 04157500, Sebewaing River State Drain near Sebewaing, Mich., and 04158000, Columbia Drain near Sebewaing, Mich., to 1,850 ft³/s at station 04101500, St. Joseph River at Niles, Mich. (Appendix A). The average index flow at selected stations was $116 \mathrm{ft}^{3} / \mathrm{s}$, the standard deviation of these flow was $228 \mathrm{ft}^{3} / \mathrm{s}$, and the (dimensionless) skewness was 4.5044 .

\section{Index Water Yield}

Much of the variability in index flow is related to drainage area (fig. 4$)^{3}$. In development of the predictive equation, there was concern that the dominant relation between index flow and drainage area indicated by the power equation $\hat{I} Q_{50}=\beta_{0} \cdot D A^{\beta_{1}}$ could mask more subtle relations involving basin and climatic characteristics. Also, the estimated exponent in the power equation, $\hat{\beta}_{1}$ of 1.2301 , implies a slightly nonlinear relation between drainage area and index flow (fig. 4). A nonlinear relation between index flow and drainage area is considered physically unlikely because much of the index flow is thought to be derived from ground-water sources, which would be approximately linearly related to drainage area $\left(\beta_{1} \simeq 1\right)$. To help identify the appropriate relations, the index water yield $I Y_{50}$ was selected as a preferred metric to the index flow. $I Y_{50}$ was estimated from station records by dividing $\tilde{I} Q_{50}$ by the drainage area upstream from the corresponding gaged site, and it is symbolized by $\tilde{I} Y_{50}$.

For the 147 selected sites, $\tilde{I} Y_{50}$ ranged from zero at the two stations with zero index flows, to $1.3087 \mathrm{ft}^{3} / \mathrm{s}-\mathrm{mi}^{2}$ at station 04139000, Houghton Creek near Lupton, Mich. The average $\tilde{I} Y_{50}$ value was $0.3302 \mathrm{ft}^{3} / \mathrm{s}-\mathrm{mi}^{2}$, the standard deviation was $0.2600 \mathrm{ft}^{3} / \mathrm{s}-\mathrm{mi}^{2}$, and the skewness was 1.3422 . The positive

\footnotetext{
${ }^{3}$ Data for two of the selected streamflow gaging stations could not be included in this plot because they were zero and could not be represented on a logarithmic scale.
} 


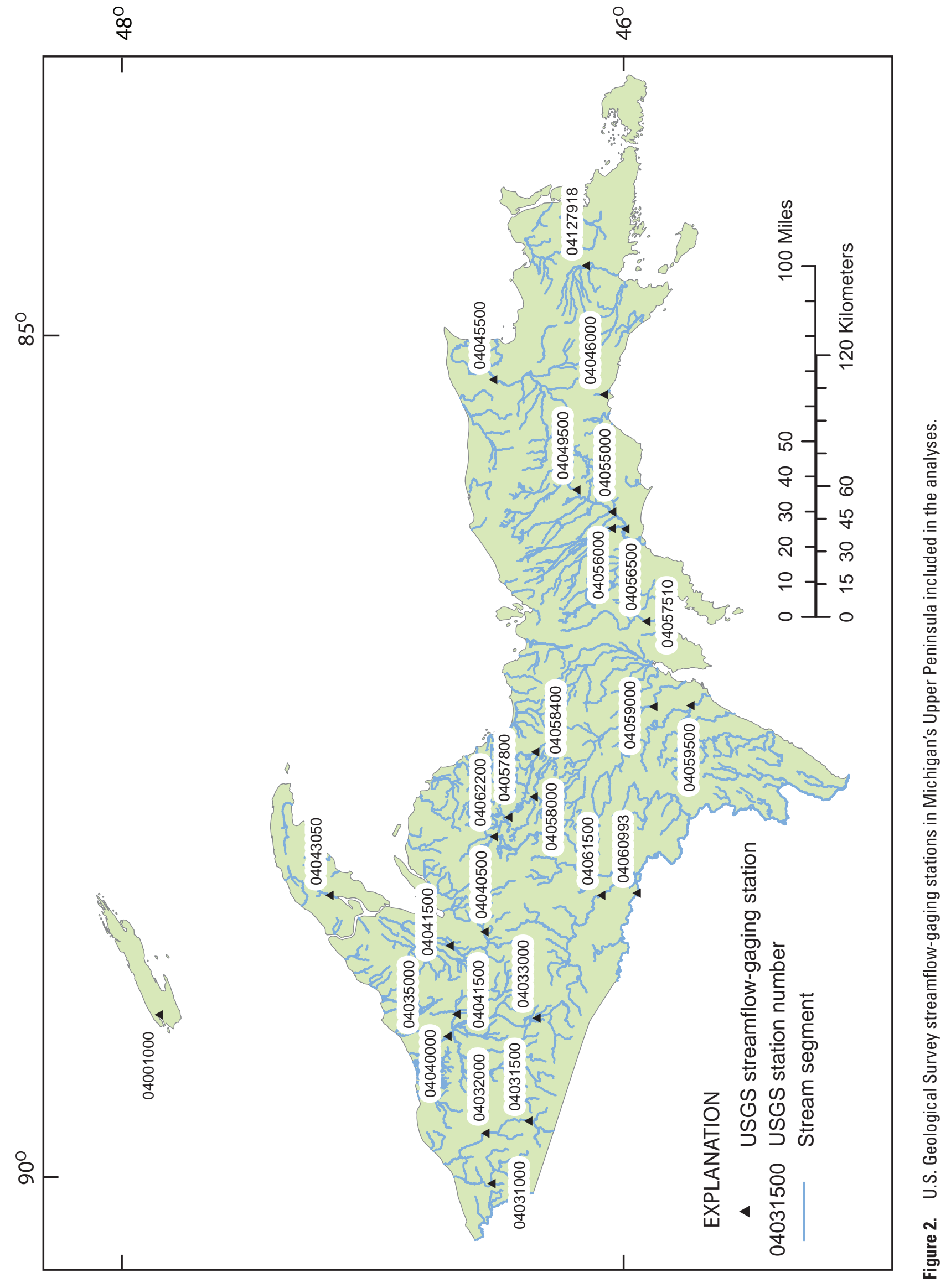




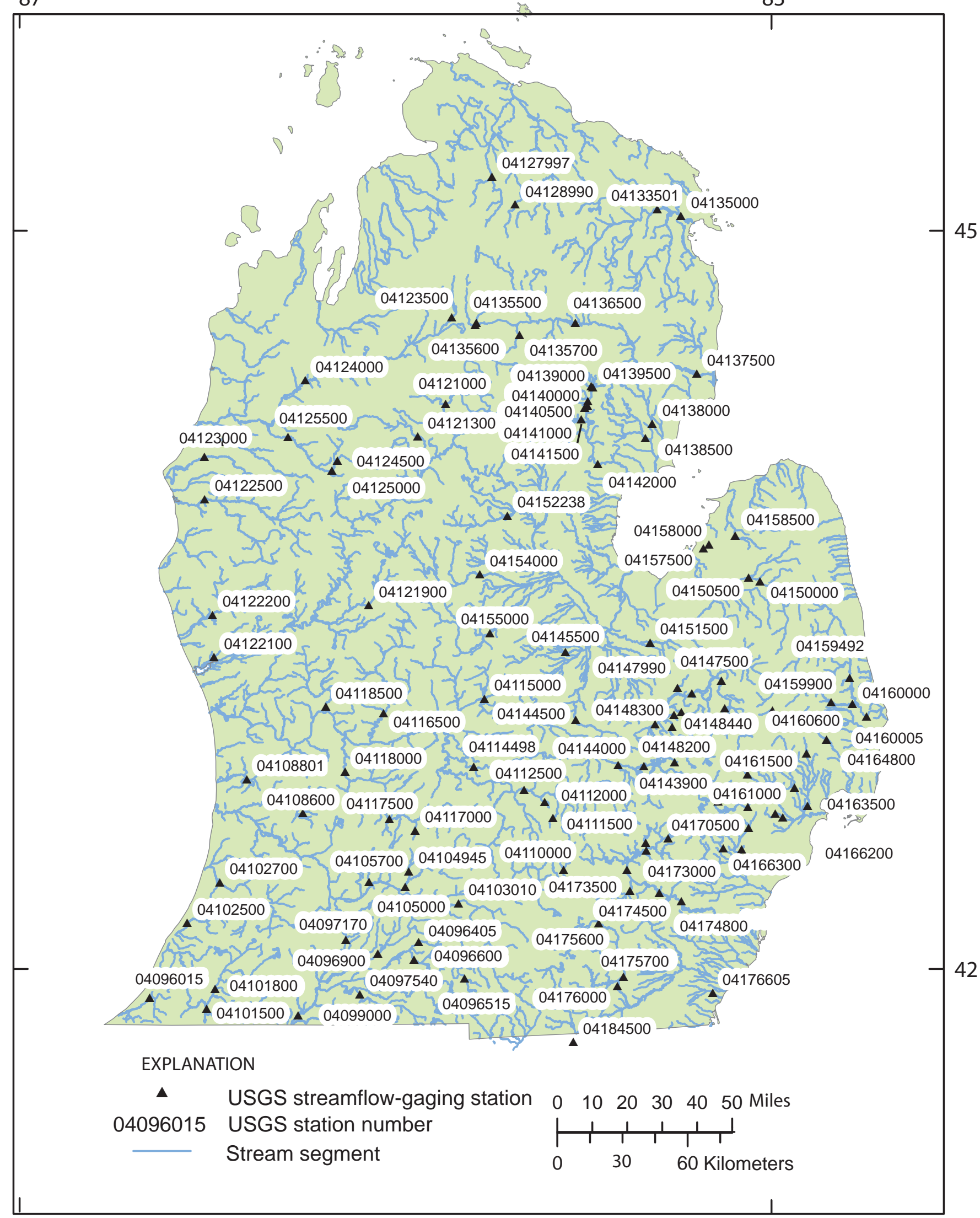

Figure 3. U.S. Geological Survey streamflow-gaging stations in Michigan's Lower Peninsula included in the analyses. 


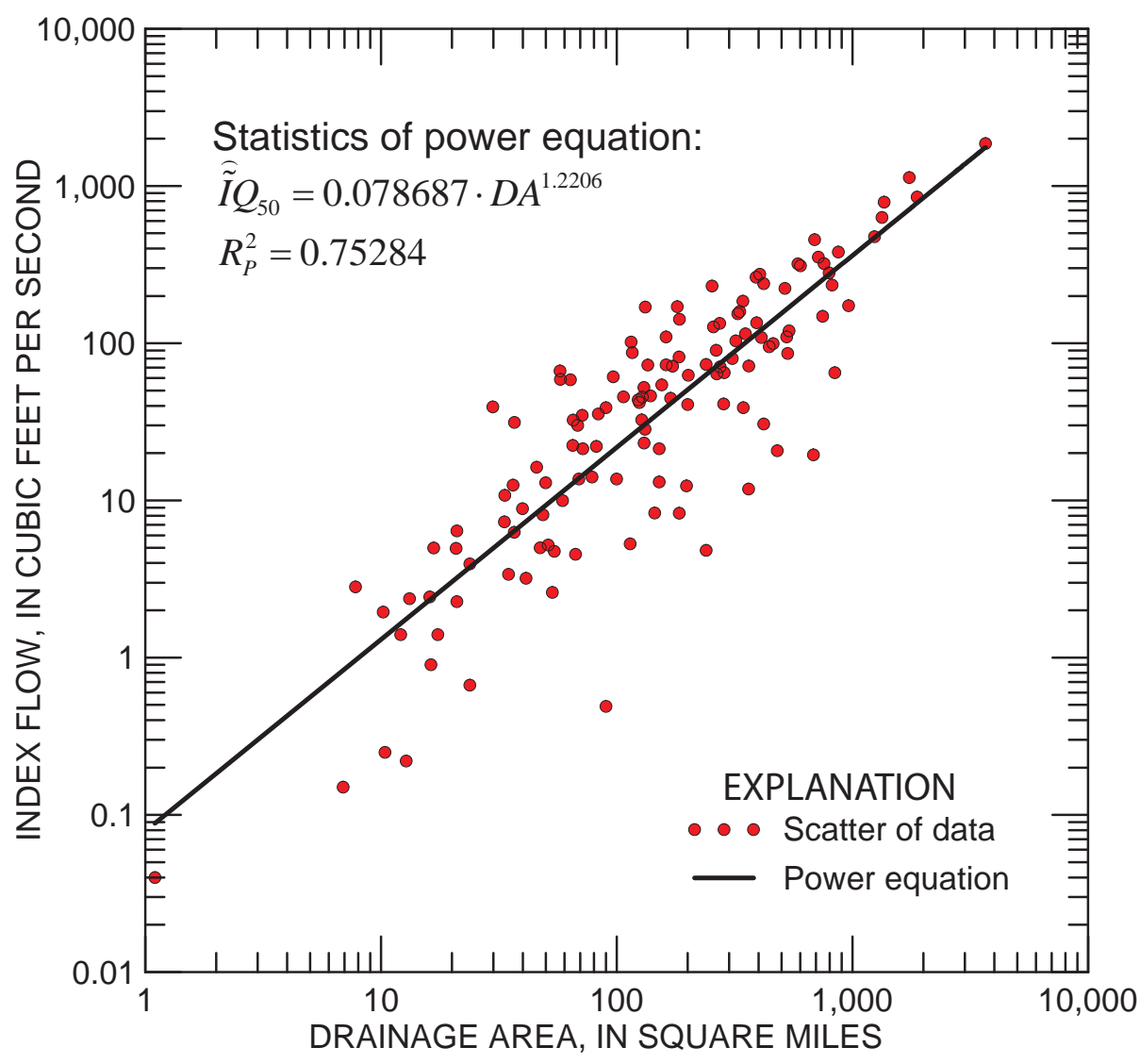

Figure 4. Relation between estimates of index flow from gaging station records, $T_{50}$, and drainage area $(D A)\left[R_{p^{\prime}}^{2}\right.$ the Pearson coefficient of determination].

skewness indicates that index water yield values are spread out more to the right than to the left of the mean. Drainage areas range from $1.1 \mathrm{mi}^{2}$ at station 04141000, South Branch Shepards Creek near Selkirk, Mich., to 3,670 $\mathrm{mi}^{2}$ at station 04101500, St. Joseph River at Niles, Mich.

A normal distribution fitted to the empirical $\tilde{I} Y_{50}$ data was inadequate to approximate the distribution of water-yield values (fig. 5), because the empirical distribution was frequently outside of the 95-percent confidence bounds of the fitted normal distribution. Formally, the Lilliefors test (Conover, 1980) rejected the null hypothesis that a normal distribution adequately approximated the distribution of $\tilde{I} Y_{50}$ at the 5-percent level $(p<0.001)$ of significance. Similarly, the Lilliefors test rejected $(p<0.001)$ the null hypothesis that a normal distribution adequately approximated the distribution of the common logarithm transform of the index yield $\left(L \tilde{I} Y_{50}\right)$.

A square-root transformation was applied to the elements of $\tilde{I} Y_{50}$ to assess the effect on the empirical distribution of the resulting values. Based on a sample mean of $0.5274\left(\mathrm{ft}^{3} / \mathrm{s}-\right.$ $\left.\mathrm{mi}^{2}\right)^{1 / 2}$, variance of $0.0525 \mathrm{ft}^{3} / \mathrm{s}-\mathrm{mi}^{2}$, and a skewness of 0.1607 , a normal distribution closely approximated the empirical distribution of square root (Root) transformed values symbol- ized as $R \tilde{I} Y_{50}$ (fig. 5). A Lilliefors Test did not reject the null hypothesis that $R \tilde{I} Y_{50}$ values were normally distributed the 5 -percent level of significance $(p=0.5)$. Therefore, the square root transformation $R \tilde{I} Y_{50}$ was used as the hydrologic-response variable in the regression model.

\section{Compilation of Hydrologic Characteristics for Use as Explanatory Variables}

Hydrologic characteristics were compiled for the 147 stations used in these analyses. Compiled hydrologic characteristics include basin and climatic characteristics that are considered physically and statistically related to the $I Y_{50}$. All hydrologic characteristics included as possible explanatory variables in the regression equation are available as Geographic Information System (GIS) files to facilitate computation of hydrologic characteristics. Basin characteristics included categories of aquifer transmissivity, forested area, and hydrologic soil group; climatic characteristics included normal (1971-2000) annual precipitation and annual snowfall amounts. The following paragraphs discuss the hydrologic 


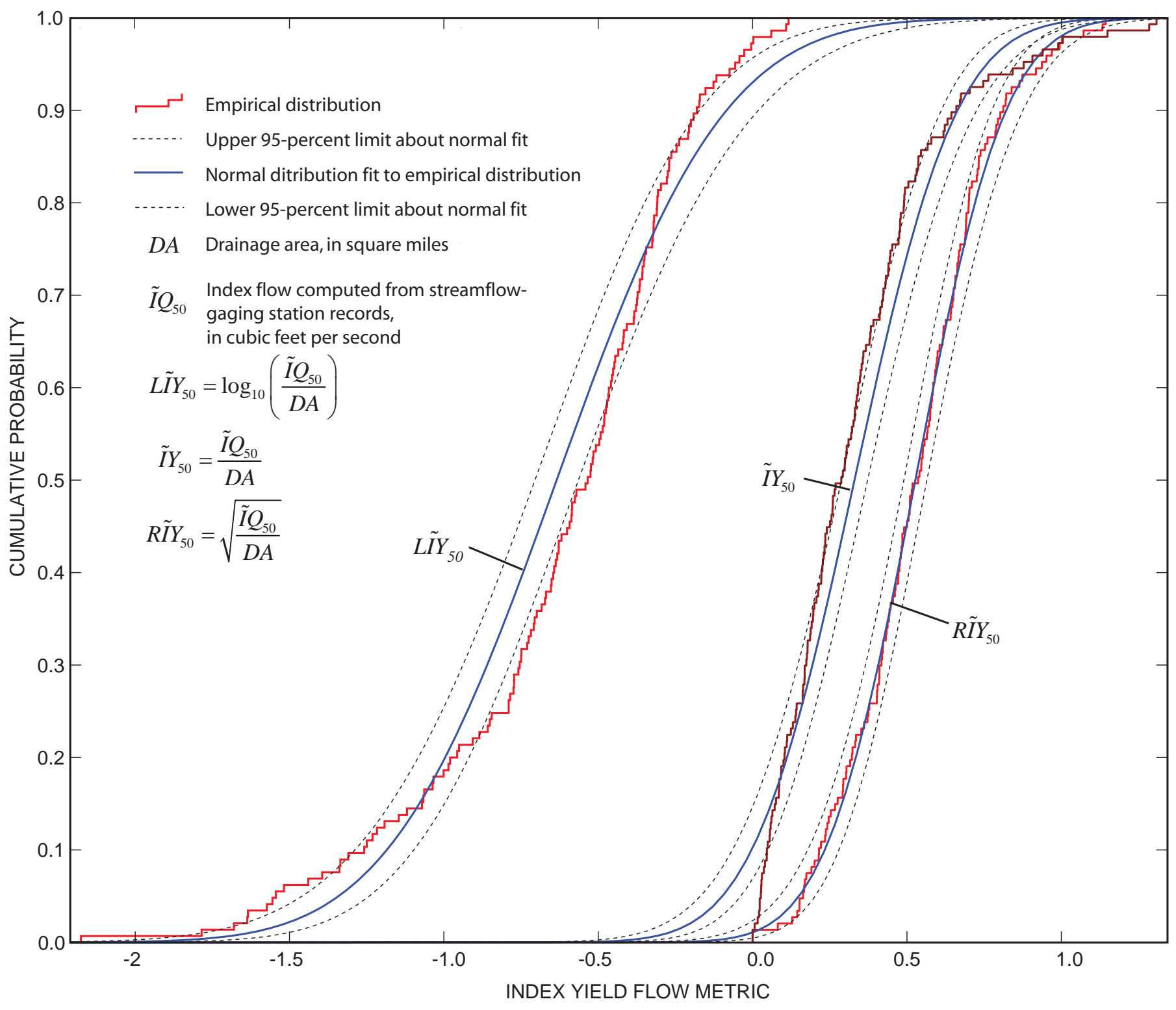

Figure 5. Empirical and fitted normal distributions for median-water-yield data from the month of lowest flow for selected streamflowgaging stations in Michigan.

characteristics evaluated as possible explanatory variables in the regression equation.

Transmissivity is a measure of the capacity of an aquifer to transmit water. The transmissivity of an aquifer is equal to its hydraulic conductivity, commonly expressed in units of feet per day, multiplied by its saturated thickness, in feet. The Goundwater Mapping Project (http://gwmap.rsgis.msu.edu/), a multiagency study in Michigan, created a grid of the estimated transmissivities for the glacial deposits (Michigan Department of Information Technology, 2005a). The grid is composed of $1-\mathrm{km}(0.621-\mathrm{mi})$ square elements and is based on an interpolation of transmissivities assigned to 270,000 water wells on the basis of lithologic information described in well logs prepared by well drillers. In areas of thin glacial deposits (less than 30 ft thick) the grid element was assigned a code of -1 to indicate that thin deposits prevented a reliable estimation of transmissivity at that element. Because of the uncertainty associated with interpolation over the highly heterogeneous aquifer transmissivity field, grid elements that were more than 2,000 $\mathrm{m}(6,560 \mathrm{ft})$ from a well were assigned a code of -2 to indicate that interpolation uncertainties prevented reliable estimation of transmissivity at that element. Otherwise, grid elements were assigned an estimated transmissivity value that ranged from 0 to $30,309 \mathrm{ft}^{2} / \mathrm{d}$.

The Michigan Glacial Landsystems Coverage (Michigan Department of Information Technology, 2005b) classified the surface geologic deposits into 10 land systems. Each applicable land system was assigned to an aquifer transmissivity 


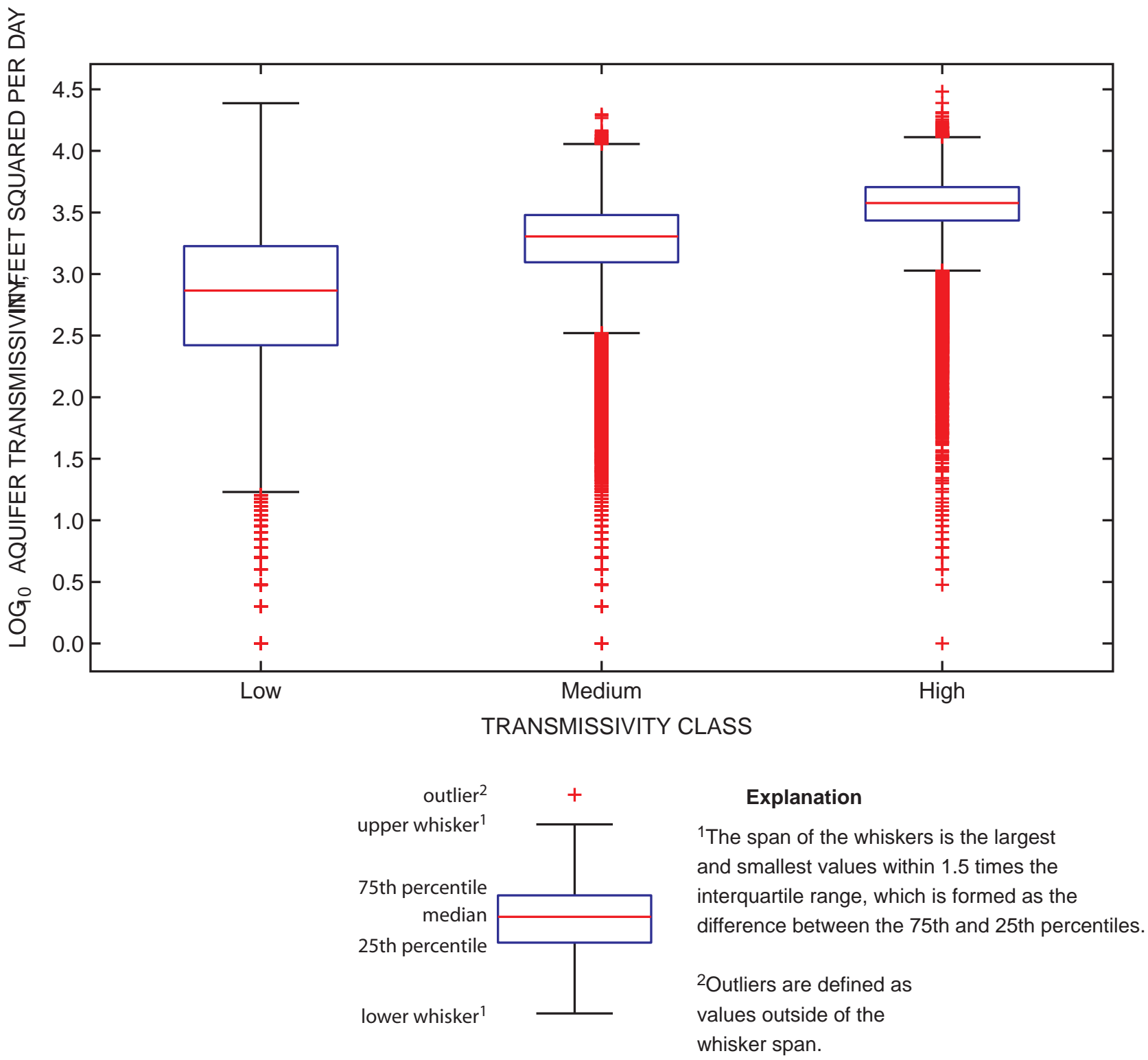

Figure 6. Distribution of estimated aquifer transmissivity within transmissivity classes in Michigan.

class. Bedrock, lacustrine fine, and thin drift over bedrock land systems were assigned to the low-transmissivity class; lacustrine coarse, lodgement till or fine supraglacial drift, and ice-marginal till land systems were classified as medium transmissivity; and coastal dunes, ice-contact outwash, and proglacial outwash were assigned to the high-transmissivity class. Land systems designated as lakes were not assigned a transmissivity class. About 0.25 percent of the elements were assigned aquifer transmissivities of zero and could not be displayed by means of a common logarithm transformation $\left(\log _{10}\right)$. The $\log _{10}$ transformed distribution of aquifer transmissivities that were estimated to be greater than zero are shown for low, medium, and high classes of transmissivities in figure 6. Median estimated aquifer transmissivities increased from $723 \mathrm{ft}^{2} / \mathrm{d}$ in areas classified as low transmissivity, to $2,020 \mathrm{ft}^{2} / \mathrm{d}$ in areas classified as medium transmissivity, to $3,780 \mathrm{ft}^{2} / \mathrm{d}$ for areas classified as high transmissivity. The spatial distribution of estimated transmissivity classes in the glacial aquifers in shown in figure 7.

Land-use and land-cover characteristics affect hydrologic response primarily by affecting the rate at which water infiltrates into the soil and subsequently either drains to the ground-water system or flows overland to a nearby stream. As indicated by Anderson and others (1976), land use refers to "man's activities on the land that are directly related to the land" (Clawson and Stewart, 1965), whereas land cover describes "the vegetative and artificial construction covering the land” (Burley, 1961). 


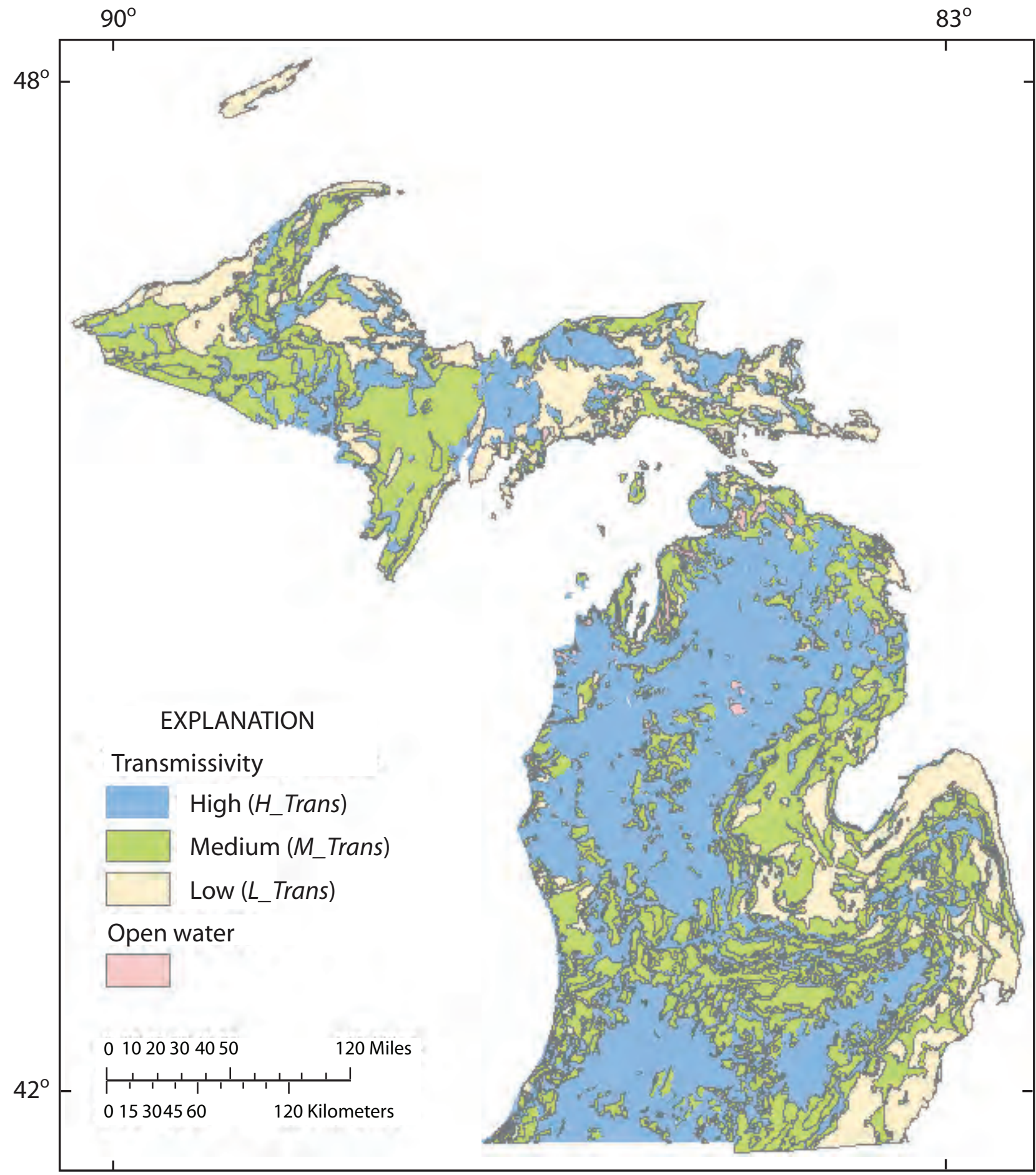

Michigan aquifer transmissivity classes from Michigan Department of Information Technology, 2005b

Figure 7. Distribution of aquifer transmissivity classes in Michigan. 
The State of Michigan uses the spatial data coverages in the Michigan Resource Information System (MIRIS) (1978) as the standard for hydrologic studies in Michigan. MIRIS contains land-use and land-cover data that had been compiled from county and regional planning commissions. The MIRIS data represent land-use and land-cover data in a grid that contains 26,319 rows and 25,247 columns of cells. Each cell represents a land area of $30 \mathrm{~m}$ square. The categories include Level I features (Anderson and others, 1976), which are coded in MIRIS as integers and are defined as follows: (1) urban or built-up land; (2) agricultural land; (3) rangeland; (4) forest land, which included Level II classification of deciduous, evergreen, and mixed forest lands; (5) water; (6) wetland; and (7) barren land. The code -9999 signifies no data or inapplicable, which occurs over areas such as the Great Lakes. The spatial distribution of forest land in the MIRIS coverage is shown in figure 8.

Four hydrologic soil groups have been defined by the U.S. Department of Agriculture Natural Resources Conservation Service (NRCS) (2007):

- Group A soils (basin characteristic variable A_Soils) have low runoff potential when thoroughly wet. Water is transmitted freely through the soil. Group A soils typically have less than 10 percent clay and more than 90 percent sand or gravel and have gravel or sand textures.

- Group B soils (B_Soils) have moderately low runoff potential when thoroughly wet. Water transmission through the soil is unimpeded. Group B soils typically have between 10 percent and 20 percent clay and 50 percent to 90 percent sand and have loamy sand or sandy loam textures.

- Group C soils (C_Soils) have moderately high runoff potential when thoroughly wet. Water transmission through the soil is somewhat restricted. Group C soils typically have between 20 percent and 40 percent clay and less than 50 percent sand and have loam, silt loam, sandy clay loam, clay loam, and silty clay loam textures.

- Group D soils (D_Soils) have high runoff potential when thoroughly wet. Water movement through the soil is restricted or very restricted. Group D soils typically have greater than 40 percent clay, less than 50 percent sand, and have clayey textures.

The spatial distribution of hydrologic soil groups in Michigan is shown on figure 9 based on the MIRIS coverage. MIRIS represents soil data in a grid that contains 26,319 rows and
25,247 columns of cells. Each cell represents a land area of $30 \mathrm{~m}$ square. In MIRIS, hydrologic group A soils are coded as 1 , group B soils are coded as 2 , group C soils are coded as 3 , group D soils are coded as 4 , and no data or inapplicable areas are coded as -9999. The hydrologic-soil-group grid is georeferenced the same as the MIRIS grid for land use and land cover.

Runoff curve numbers $(R C N)$ were developed by the U.S. Department of Agriculture National Resources Conservation Service (2004). Conceptually, $R C N$ describes the direct runoff component of total flow that includes (1) the channel component representing precipitation falling directly on the stream channel, (2) the surface or overland flow component, which represents flow from precipitation that exceeds the infiltration rate on the land surface, and (3) the subsurface component, which represents infiltrated water that flows laterally underground to the stream without intercepting permanently saturated areas; this subsurface flow component is sometimes referred to as "interflow." With reference to $R C N$, runoff does not include the base-flow component, which is likely the main component influencing $I Q_{50}$. Large direct-runoff components, however, are likely to be associated with smaller median or base-flow components. In general, greater $R C N$ values are associated with soils with greater peak runoff potential, such as areas underlain the hydrologic soil group $\mathrm{D}$; within each soil group, $R C N$ increases with percentages of impervious areas, land covers that are prone to produce runoff, and basins that are considered to be in poor hydrologic condition. The MDEQ has developed GIS processing techniques for computing $R C N$ from land-use and soil GIS coverages. From a possible range of 0 (no direct runoff) to $100, R C N$ ranged from 48 to 85, with an average of 70 for the selected basins. No statewide coverage is available to display the geographic variation of $R C N$, although it is similar to the hydrologic soil groups and land-use characteristics from which it is derived.

Normal annual precipitation for 1971-2000 ranged from about $28.5 \mathrm{in} / \mathrm{yr}$ in the northeastern part of the Lower Peninsula to about $38 \mathrm{in} / \mathrm{yr}$ in southeastern part of the Lower Peninsula (Michigan Climatological Resources Program, 2004). Precipitation in the far western part of the Upper Peninsula approaches $35 \mathrm{in} / \mathrm{yr}$, whereas precipitation in the eastern part is about $32 \mathrm{in} / \mathrm{yr}$ (fig. 10).

Normal annual snowfall depths (fig. 11) for 1971-2000 in Michigan generally trend from a minimum of 40 in. in southeastern Lower Peninsula to a maximum of 220 in. in the northwestern tip of the Upper Peninsula (Michigan Climatological Resources Program, 2004). Evidence of lake-effect snow is apparent along the western coast of the Lower Peninsula and in a trend of increasing snowfall depths from south to north in the Upper Peninsula. 


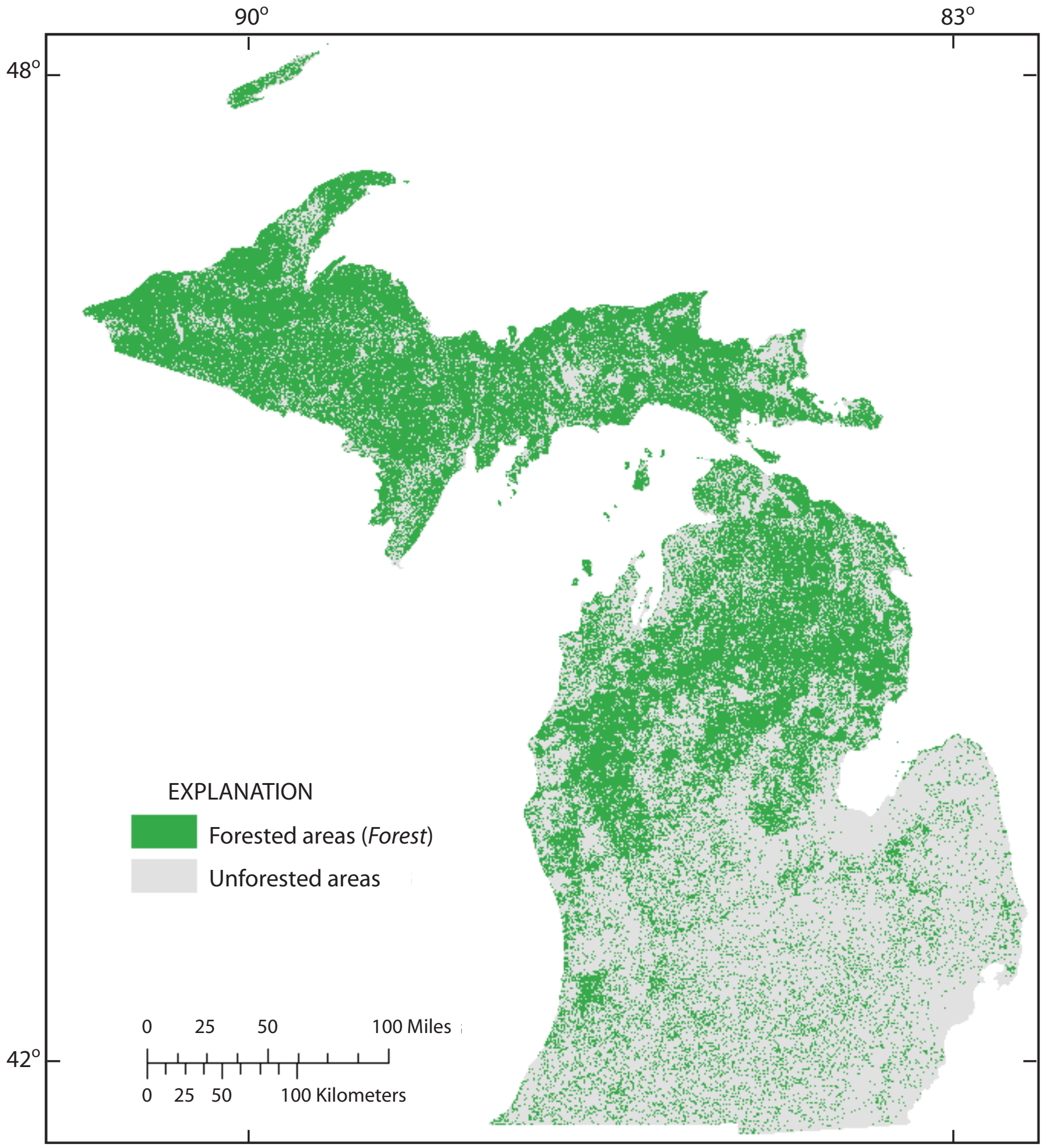

Land cover from Michigan Resource Information System, 1978a.

Figure 8. Distribution of forest cover in Michigan. 


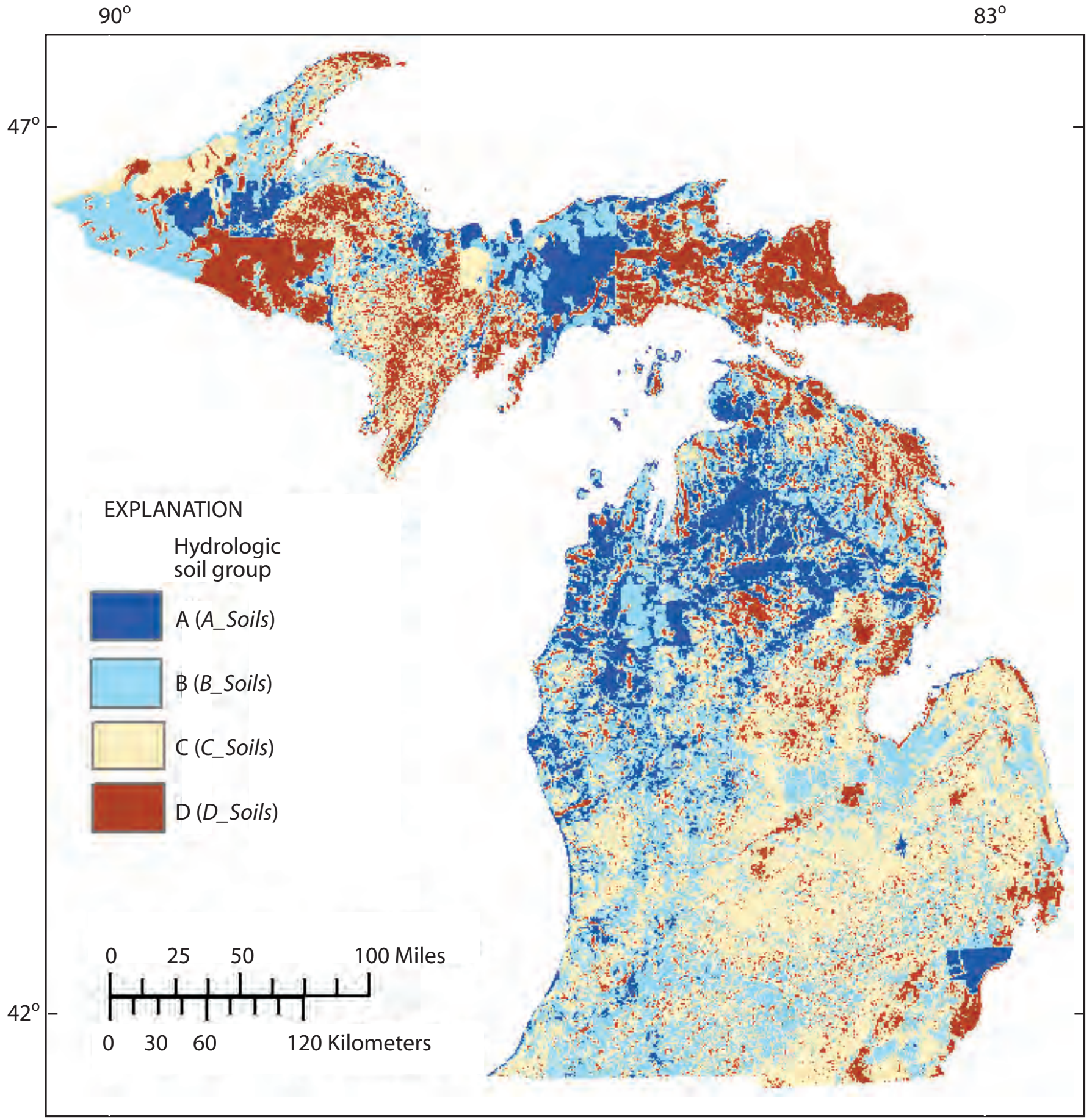

Hydrologic soil groups from Michigan Resource Information System, 1978a.

Figure 9. Distribution of hydrologic soil groups in Michigan. 


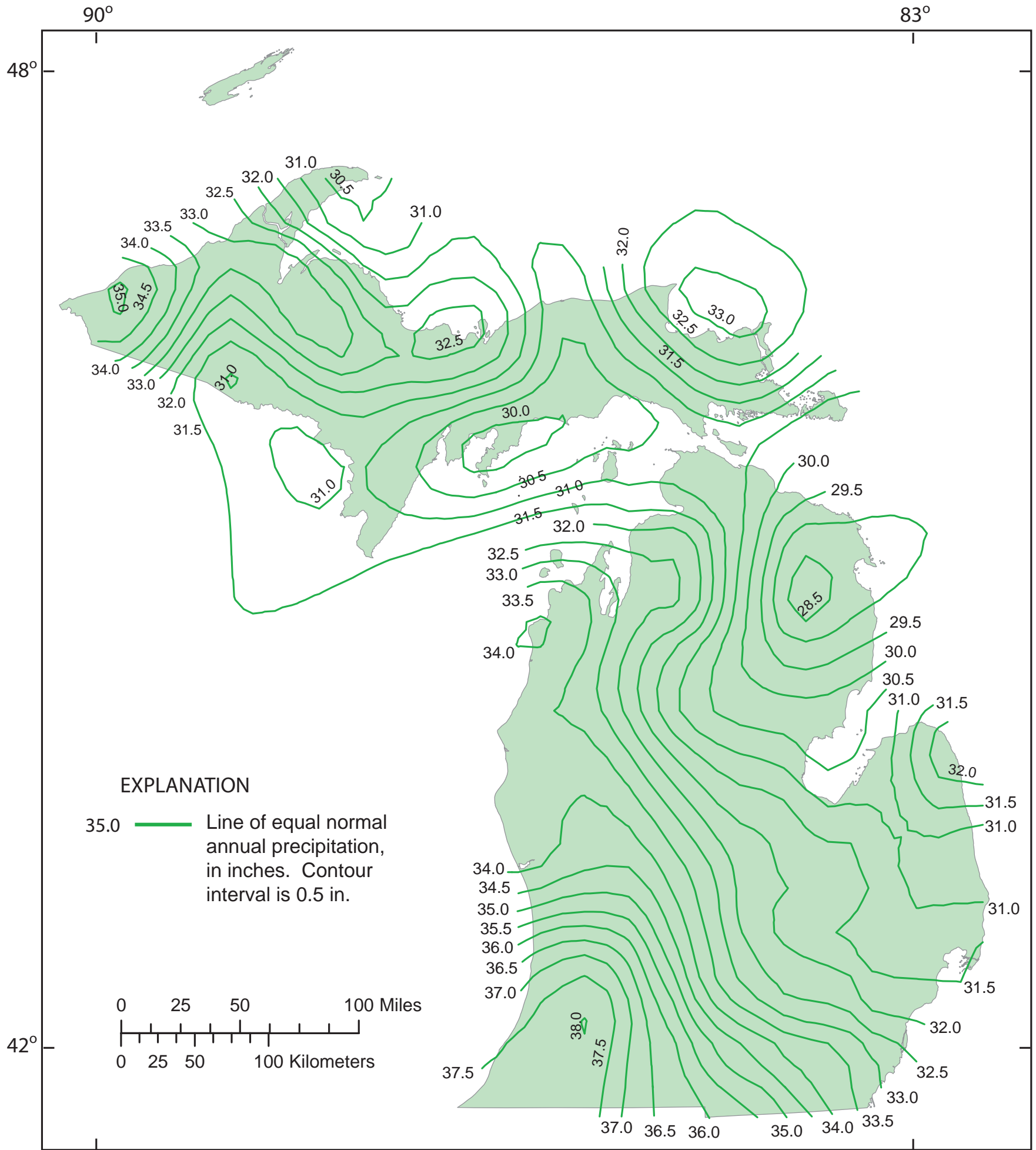

Normal annual precipitation from Michigan Climatological Resources Program, 2004.

Figure 10. Distribution of normal annual precipitation in Michigan for 1971-2000. 


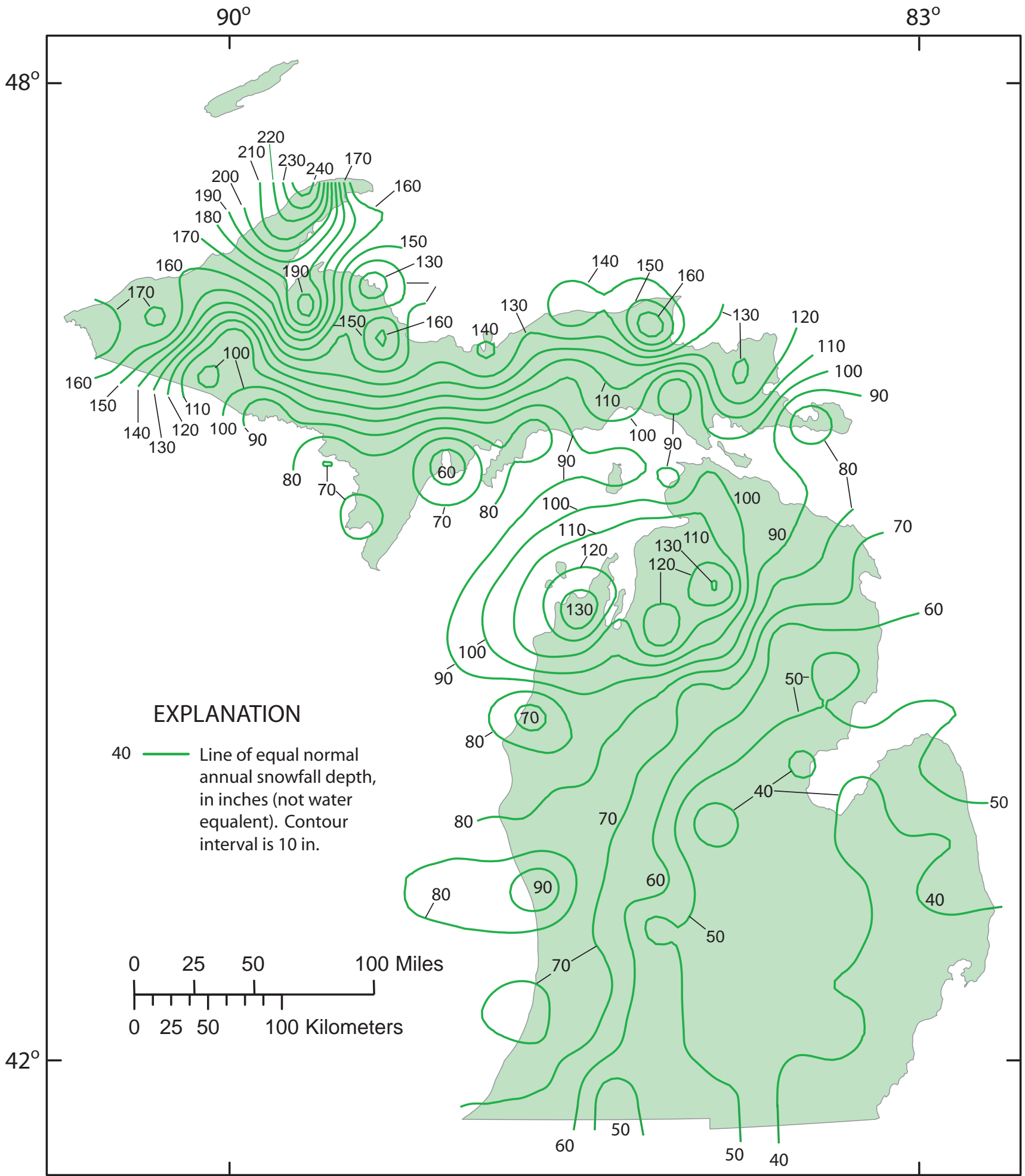

Snowfall depths from Michigan Climatological Resources Program, 2004.

Figure 11. Distribution of normal annual snowfall depths in Michigan for 1971-2000. 


\section{Selection of Hydrologic Characteristics for Use as Explanatory Variables}

Explanatory variables used in the regression equation were selected on the basis of both their statistical and hydrologic significance. One of the initial screening devices for assessing statistical associations was the matrix of correlation coefficients (table 1). Here, the maximum positive correlation (0.63) was found between $R \tilde{I} Y_{50}$ and forest (Forest); the maximum negative correlation $(-0.72)$ was found between $R \tilde{I} Y_{50}$ and runoff curve numbers $(R C N)$. Among explanatory variables, large negative correlations were detected between $R C N$ and $A \_$Soils (-0.90). A large positive correlation also was found between Snowfall and Forest (0.83).

Correlations between explanatory variables indicate some redundancy of information and result in some statistical ambiguity in identifying explanatory variables for inclusion in the regression equation. Percentages of land use classified within individual categories of both transmissivity and soil groups generally summed to 100 percent, except in some areas where soils or glacial drift were absent and the sum therefore was less than 100 percent. For these two sets of variables, intragroup categories were negatively correlated. Also, because the sums of all transmissivity and soil categories generally were 100 percent, all members of either the transmissivity or soil categories could not be included in the regression without special numerical constraints.

Initial development of the regression equation proceeded in an automated, stepwise manner. In particular, the variable most highly correlated with $R \tilde{I} Y_{50}$ was added to the equation first, followed by the variable that was most highly correlated given the presence of the first variable in the equation. The process continued until all the alternative explanatory variables were evaluated in turn. Introduction of new variables into the equation sometimes resulted in the elimination of variables previously included at an apparent significance level of 0.15 .

Final selection of the regression equation was based on the following criteria:

- The model explained a significant amount of the variability in $R \tilde{I} Y_{50}$.

- The estimation error of the overall model was low.

- The number of selected explanatory variables was constrained so that model prediction error-the error applicable to sites not included in the development of the equation—would be similar to model estimation error.

- The signs and magnitudes of parameters associated with selected explanatory variables were generally consistent with the expected physical association between the individual explanatory variables and the hydrologic response.
- An apparent significance level of about 5 percent for individual parameters was generally maintained.

\section{Estimation of the Hydrologic Response Variables}

The regression equation for estimating the hydrologic response variable, $R \tilde{I} Y_{50}$, contains six explanatory variables and an intercept term. Based on the computed $R_{a d j}^{2}$ value, the regression model explains about 70.8 percent of the variability in $R \tilde{I} Y_{50}$ (fig. 12). The $R M S_{E}$ was 0.12377 , with corresponding $M S_{E}$ or $s^{2}$ equal to 0.015320 , and overall the $p$-value associated with the regression model was less than $0.0001(p<0.0001)$. Based on the results of a Lilliefors test of normality, there was insufficient evidence to reject the normality of the residual distribution at the 0.01 level of significance $(p=0.015)$. In this report, estimates of the index water yield, $\hat{I} Y_{50}$, were obtained by squaring estimates of $R \hat{I} Y_{50}$. After squaring individual values of $R \tilde{I} Y_{50}$ and $R \hat{I} Y_{50}$ to compute $\tilde{I} Y_{50}$ and $\hat{I} Y_{50}$ values, respectively, the $R_{p}^{2}\left(R \tilde{I} Y_{50}, R \hat{I} Y_{50}\right)$ decreases from the 0.7080 determined in the regression to an $R_{p}^{2}\left(\tilde{I} Y_{50}, \hat{I} Y_{50}\right)$ of 0.6128 because of the skewed distribution of the squared values. The coefficient of determination based on the ranks of the squared values $R_{S}^{2}\left(\tilde{I} Y_{50}, \hat{I} Y_{50}\right)$, however, is 0.7498 , which is slightly higher than the $R_{p}^{2}\left(R \tilde{I} Y_{50}, R \hat{I} Y_{50}\right)$ of the more normally distributed $R \tilde{I} Y_{50}$ and $R \hat{I} Y_{50}$ values. Thus, the correlation between measured and estimated index water yield is preserved in the space appropriate to the distribution of the two variables. The mean and standard deviation of residuals between measured and estimated water-yield values are 0.0151 , and 0.1622 , respectively.

Explanatory variables included in the regression model, parameter estimates, and associated statistics are listed in table 2. Only the parameter associated with low transmissivity ( $L \_$Trans) was negatively associated with $R \tilde{I} Y_{50}$. In apparent contradiction to the suspected physical relation, the parameter associated with $D \_S o i l s$ is positively associated with $R \tilde{I} Y_{50}$ and is similar in magnitude to the parameter associated with A_Soils. The anomalous sign associated with $D \_$Soils may be related to an association between $D \_S o i l s$ and other land-use and land-cover characteristics.

To investigate this possibility, a cross tabulation between the 1978 MIRIS land use-land cover areas with hydrologic soil groups was computed (table 1-3 of Appendix 1). The results of this tabulation indicate that 89.3 percent of the areas classified as water also were classified as group D soils and that 68.7 percent of the areas classified as wetlands also were classified as group D soils (table 3). Furthermore, 60.4 percent of the soils classified as group $\mathrm{D}$ also were classified as forest areas. Areas covered by water, wetlands, and forests would be expected to be associated with higher median flows than areas not associated with these land use-land cover characteristics. Thus, the positive sign of the parameter estimate for $D \_S o i l s$ is not considered physically anomalous. 
Table 1. Lower triangular elements of the diagonally symmetric correlation matrix among candidate explanatory variables and the square root of median water yield for the summer month of lowest flow in Michigan.

[H_Trans, M_Trans, and L_Trans indicate the percentage of the land area underlain by high, medium, and low aquifer transmissivity classes, respectively; Forest indicates forest-covered lands; $A \_S o i l s, B \_S o i l s, C$ _Soils, and D_Soils indicate the percent of land areas classified as hydrologic soil group A, B, C, and D, respectively; $R C N$ indicates the runoff curve number; Precip indicates the normal annual precipitation for 1971-2000; Snowfall indicates the snowfall depths (not water equivalent); and $R \tilde{I} Y_{50}$ indicates the square root of the index water yield]

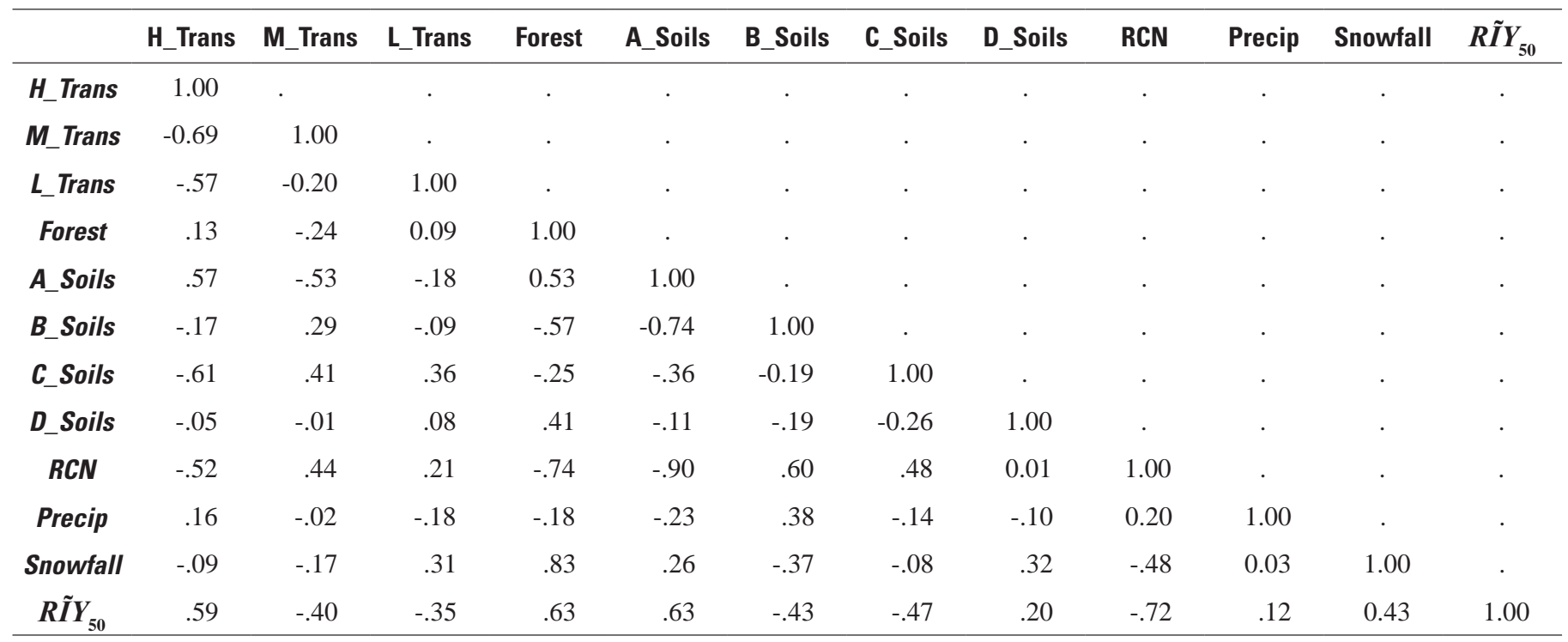

Correlations among parameter estimates for explanatory variables (excluding the intercept term) ranged from -0.6398 to 0.5075 (table 4), indicating no significant linear dependence among explanatory variables. Some ambiguity between the intercept term, which is associated with the leading column of 1 's in the design matrix, and the parameter estimate associated with Precip is indicated by a correlation of -0.9881 .

Values of the selected explanatory variables for all 147 observations used in regression model are in table 1-2 of Appendix 1. If a unit vector of equal length were appended before columns 3-8 in table 1-2, the table entries would be identical to the design matrix $X$ used in the development of the regression model. Boxplots show the range and approximate distribution of the selected explanatory variables used in the regression equation (fig. 13).

\section{Spatial Distribution of the Regression-Model Error}

Taken over all streamflow-gaging stations in the analysis, the multiple linear regression equation developed in the report provides an unbiased estimator, $R \hat{I} Y_{50}$, of $R \tilde{I} Y_{50}$. Estimation of spatially referenced quantities without corresponding spatially referenced gaging-station coordinates as explanatory variables, however, can result in spatial patterns in the regression error. A significant spatial pattern in the distribution of regression errors would indicate that estimates could be locally biased.

To investigate the potential for local bias in regression estimates, each selected gaging station was assigned to a subregion within Michigan (fig. 14). The subregions used in this report are similar to subregions defined on USGS hydrologic unit maps (Seaber and others, 1987). So that similar numbers of streamflow-gaging stations would be included in each subregion, however, individual cataloging units shown on USGS hydrologic unit maps were grouped somewhat differently in this report than cataloging units grouped by the USGS to define subregions. In addition, the cataloging units forming the subregions in this report were clipped to the State's boundaries.

Notched boxplots show the distribution of model residuals by subregion (fig. 15). For each boxplot, the width of the notch is computed so that boxplots whose notches do not overlap would have different medians at the 5-percent level of significance. By examining the intervals spanned by the notches, however, the boxplots indicate no significant difference in median residual among hydrologic subregions. Similarly, a Kruskal-Wallis test (Conover, 1980), which compares the median residuals for each subregion, found no significant differences among subregions $(p=0.3515)$. The lack of geographic bias among subregions implies that the regression equation is applicable for all hydrologic subreaches, which together span the State of Michigan. The median residual of -0.0438 in Michigan hydrologic subregion 7 is slightly less than zero. A bootstrap analysis of residuals in subregion 7 alone, however, did not indicate that the median residual was biased at the 5-percent level of significance. 


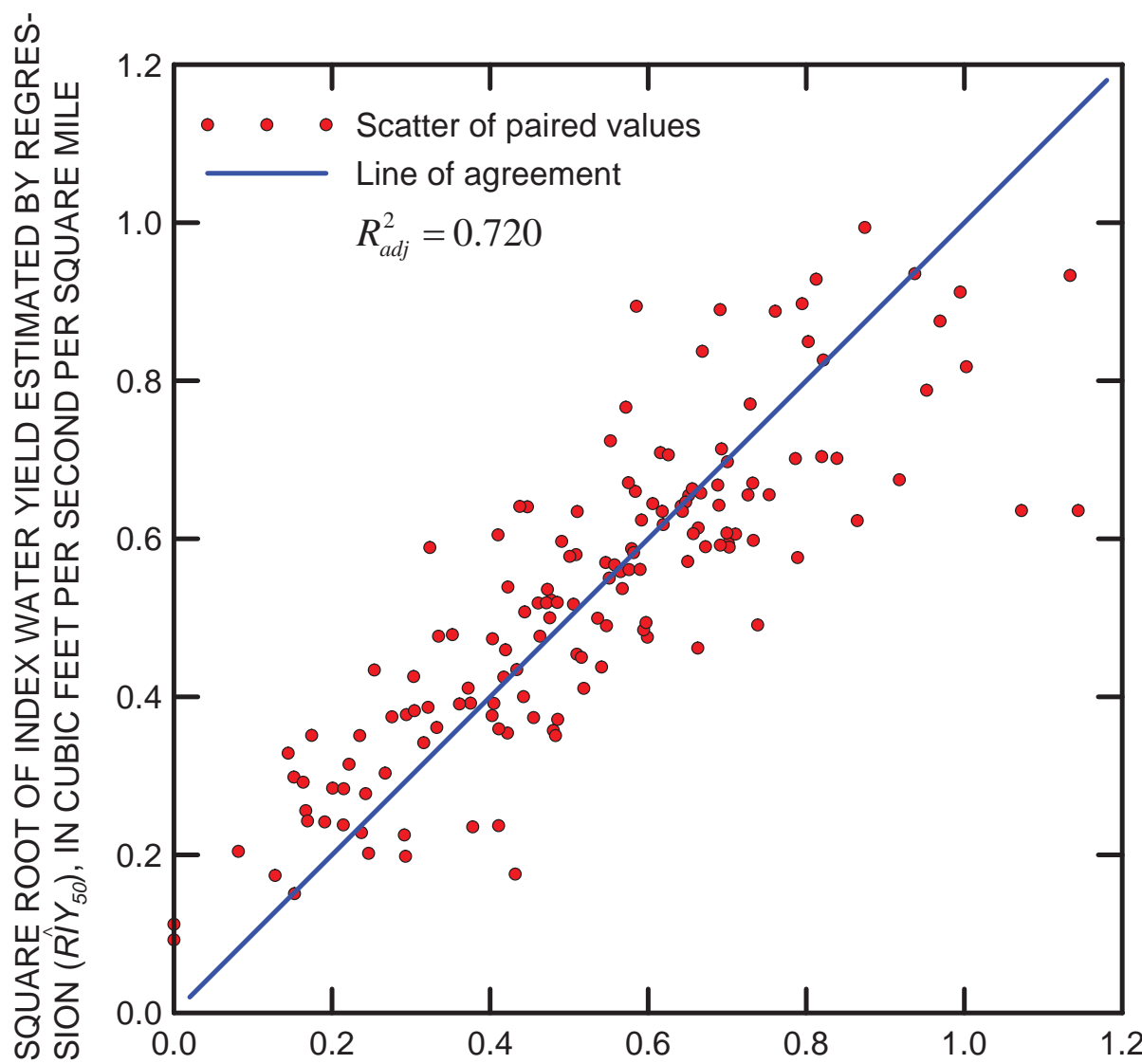

SQUARE ROOT OF INDEX WATER YIELD COMPUTED FROM STEAMFLOW-GAGING STATION RECORDS, $\widetilde{R I Y}{ }_{50}$, IN CUBIC FEET PER SECOND PER SQUARE MILE

Figure 12. Relation between $R \hat{I}_{50}$ (the index of water yield estimated by regression) and $R \tilde{I}_{50}$ (the index of water yield computed on the basis of the streamflow-gaging station records) $\left[R_{a d j}^{2}\right.$, the adjusted Pearson coefficient of determination].

Table 2. Regression-model parameters for estimating the hydrologic response variable.

[Intercept refers to a leading column of ones in the design matrix; $L \_$Trans refers to the percentage of the basin classified as having low ground-water transmissivity; $H_{-}$Trans refers to the percentage of the basin classified as having high ground-water transmissivity; Forest refers to the percentage of the basin where land cover is classified as forest; Precip refers to the normal annual precipitation for the period 1971-2000, in inches; and A_Soils and D_Soils refer to the percentage of the basin classified in the A and D hydrologic soil groups, respectively]

\begin{tabular}{llcccr}
\hline Index $\boldsymbol{i}$ & $\begin{array}{c}\text { Hydrologic } \\
\text { characteristic }\end{array}$ & $\begin{array}{c}\text { Parameter estimate } \\
\boldsymbol{\beta}_{\boldsymbol{i}}\end{array}$ & $\begin{array}{c}\text { Standard error of the } \\
\text { parameter estimate }\end{array}$ & $\begin{array}{c}\text { Student's } \boldsymbol{t} \\
\text { statistic }\end{array}$ & $\boldsymbol{p}$-value \\
\hline 0 & Intercept & -0.541982 & 0.1910 & -2.838 & 0.0052 \\
1 & L_Trans & -.00136258 & .0005397 & -2.524 & .0127 \\
2 & H_Trans & .00204796 & .00051078 & 4.010 & $<.0001$ \\
3 & Forest & .00402190 & .0005452 & 7.377 & $<.0001$ \\
4 & Precip & .0236424 & .005778 & 4.092 & $<.0001$ \\
5 & A_Soils & .00225536 & .0007683 & 2.935 & .0039 \\
6 & D_Soils & .00162107 & .001136 & 1.427 & .1557 \\
\hline
\end{tabular}

Equation for predicting the hydrologic response variable:

$R \hat{I I} Y_{50}=\beta_{0}+\beta_{1} \cdot L \_$Trans $+\beta_{2} \cdot H \_$Trans $+\beta_{3} \cdot$ Forest $+\beta_{4} \cdot$ Precip $+\beta_{5} \cdot A \_$Soils $+\beta_{6} \cdot D \_$Soils 
Table 3. Cross-tabulation of land use-land cover areas with hydrologic soil groups for land areas within Michigan.

\begin{tabular}{|c|c|c|c|c|c|c|}
\hline \multirow{2}{*}{$\begin{array}{l}\text { Land use/ } \\
\text { land cover }\end{array}$} & \multicolumn{6}{|c|}{ Hydrologic soil group } \\
\hline & A & B & C & D & No data ${ }^{1}$ & Percent \\
\hline \multicolumn{7}{|c|}{ Percentages of soil group by land use/land cover } \\
\hline Urban & 41.4 & 42.3 & 10.8 & 5.3 & 0.1 & 100 \\
\hline Agriculture & 16.7 & 54.5 & 24.7 & 4.1 & 0.0 & 100 \\
\hline Range land & 39.4 & 31.7 & 10.0 & 18.9 & 0.0 & 100 \\
\hline Forest & 38.9 & 24.5 & 7.7 & 28.4 & 0.6 & 100 \\
\hline Water & 3.9 & 5.1 & 0.6 & 89.3 & 1.1 & 100 \\
\hline Wetland & 16.8 & 10.1 & 3.6 & 68.7 & 0.7 & 100 \\
\hline Barren & 48.6 & 4.2 & 4.5 & 22.7 & 20.0 & 100 \\
\hline No data $^{1}$ & 0.0 & 0.0 & 0.0 & 0.1 & 99.9 & 100 \\
\hline \multicolumn{7}{|c|}{ Percentages of land use/land cover by soil group } \\
\hline Urban & 8.5 & 7.9 & 5.4 & 1.4 & 0.0 & -- \\
\hline Agriculture & 15.9 & 47.3 & 57.1 & 5.2 & 0.0 & -- \\
\hline Range land & 10.3 & 7.5 & 6.3 & 6.6 & 0.0 & -- \\
\hline Forest & 61.9 & 35.4 & 29.6 & 60.4 & 0.1 & -- \\
\hline Water & 0.3 & 0.3 & 0.1 & 8.8 & 0.0 & -- \\
\hline Wetland & 2.8 & 1.5 & 1.5 & 15.5 & 0.0 & -- \\
\hline Barren & 0.2 & 0.0 & 0.0 & 0.1 & 0.0 & -- \\
\hline No data & 0.1 & 0.0 & 0.0 & 1.8 & 99.9 & -- \\
\hline Percent & 100 & 100 & 100 & 100 & 100 & -- \\
\hline
\end{tabular}

1 "No data" indicates that a cell in the Michigan Resource Information System coverage was coded as -9999. The nodata codes typically represented areas outside the land areas in Michigan. Generally, 99.9 percent of the time, a no-data code for land use-land cover corresponded to a no-data code for hydrologic soil group. Occasionally, no-data codes did not match between coverages.

Table 4. Lower triangular elements of the diagonally symmetric correlation matrix among parameters of selected explanatory variables and the square root of median water yield for the summer month of lowest flow in Michigan.

[Intercept refers to a leading column of 1's in the design matrix; L_Trans refers to the percentage of the basin classified as having low ground-water transmissivity; $H \_$Trans refers to the percentage of the basin classified as having high ground-water transmissivity; Forest refers to the percentage of the basin where land cover is classified as forest; Precip refers to the normal annual precipitation for the period 1971-2000, in inches; and A_Soils and D_Soils refer to the percentage of the basin classified in the A and D hydrologic soil groups, respectively]

\begin{tabular}{cccccccc}
\hline Parameter & Intercept & \multicolumn{1}{c}{ L_Trans } & H_Trans & Forest & Precip & A_Soils & D_Soils \\
\hline Intercept & 1 &. &. &. &. &. &. \\
L_Trans & -0.1252 & 1 &. &. &. &. &. \\
H_Trans & .2255 & 0.5075 & 1 &. &. &. &. \\
Forest & .1065 & -.0545 & 0.2581 & 1 &. &. &. \\
Precip & -.9881 & .0432 & -.3134 & -0.1215 & 1 &. &. \\
A_Soils & -.3706 & -.0988 & -.6260 & -.6398 & 0.3780 & 1 &. \\
D_Soils & -.2477 & -.0231 & -.2292 & -.5779 & .1899 & 0.4752 & 1 \\
\hline
\end{tabular}



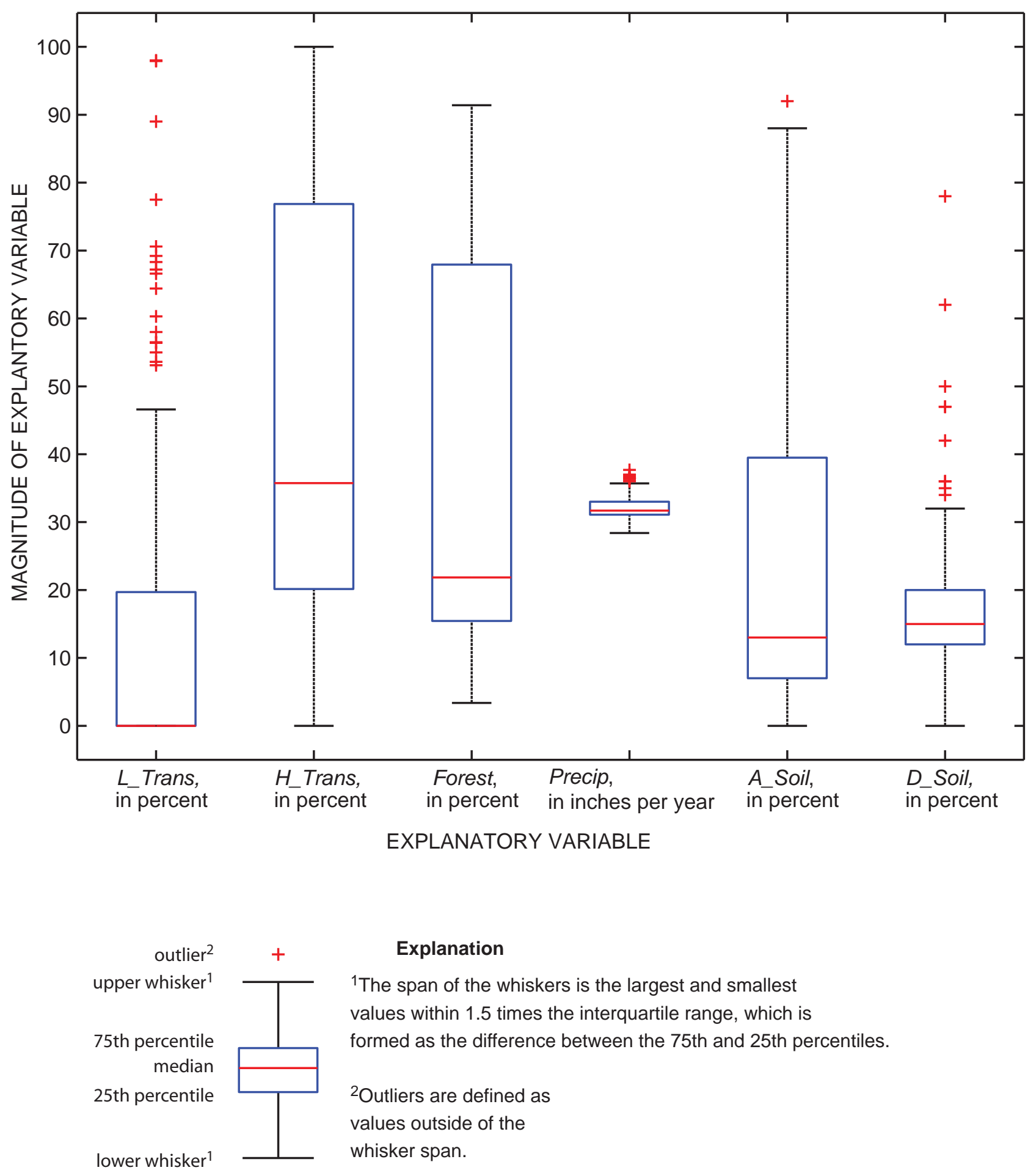

\section{Explanation}

${ }^{1}$ The span of the whiskers is the largest and smallest values within 1.5 times the interquartile range, which is formed as the difference between the 75th and 25th percentiles.

${ }^{2}$ Outliers are defined as values outside of the whisker span.

Figure 13. Distribution of explanatory variables selected for the regression model. 


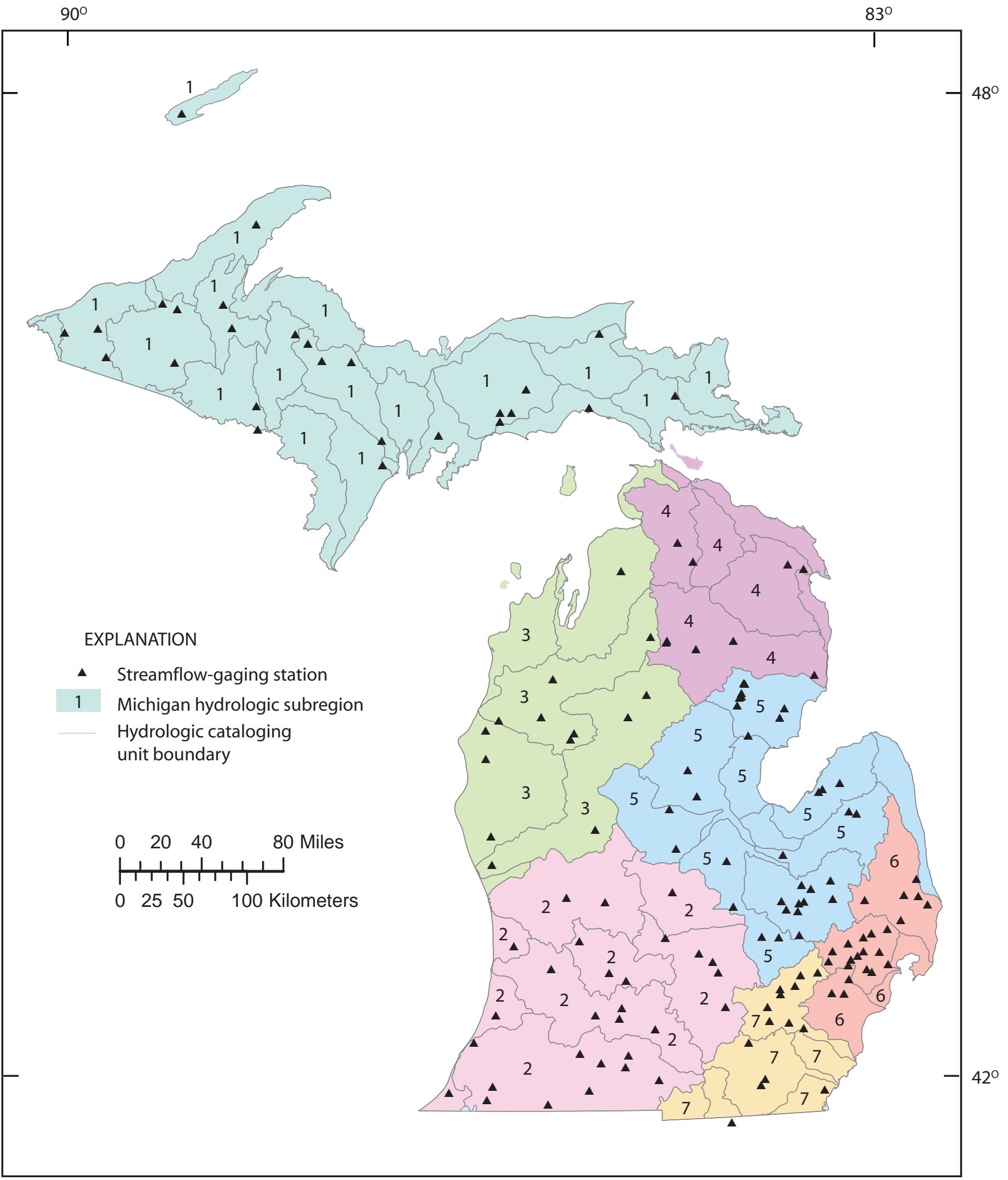

Figure 14. Hydrologic subregions used in the analysis of the spatial distribution of regression-model error. 

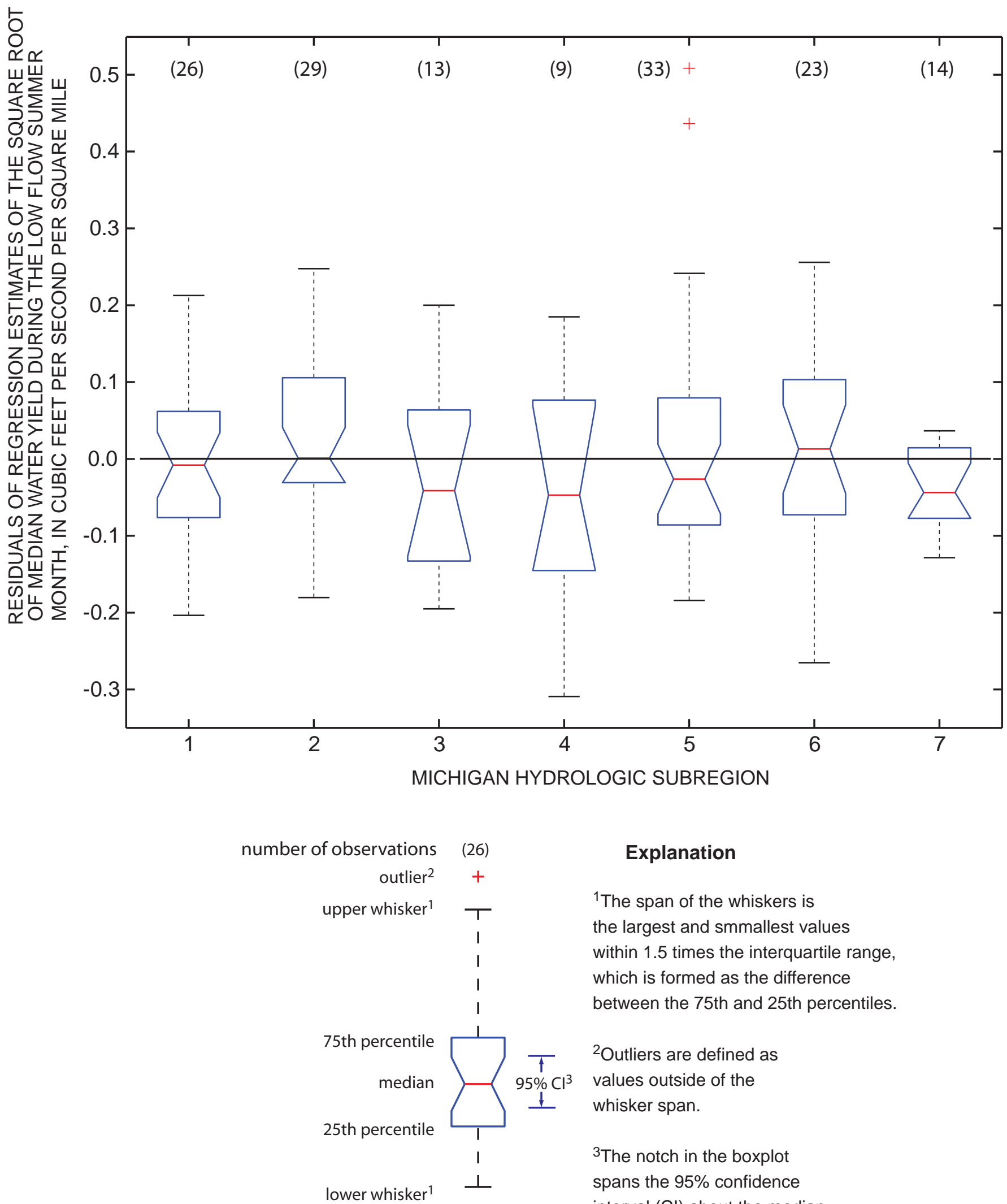

\section{Explanation}

${ }^{1}$ The span of the whiskers is the largest and smmallest values within 1.5 times the interquartile range, which is formed as the difference between the 75th and 25th percentiles.

${ }^{2}$ Outliers are defined as values outside of the whisker span.

${ }^{3}$ The notch in the boxplot spans the $95 \%$ confidence interval $(\mathrm{Cl})$ about the median.

Figure 15. Regional distribution of regression-model errors for estimating median water yield during the summer month of minimum flow. 


\section{Computation of the Index Flow}

The following sections describe computation of the index flow, $\hat{I} Q_{50}$, which involves squaring the hydrologic response variable (the estimated square root of the index water yield), symbolized as $R \hat{I} Y_{50}=\hat{I} Y_{50}$, and multiplying by the corresponding drainage area. Using $\hat{I} Y_{50}$, the assumption of linearity between drainage area and index flow is evaluated. Then, the match between the index flows determined from the analysis of streamflow-gaging station records and index flows computed on the basis of regression estimates are compared. Finally, an example is provided for computing the index flow, $\hat{I} Q_{50}$, given values for selected explanatory variables, and the upper and lower prediction limits, $\hat{U} P L_{1-\alpha / 2}$ and $\hat{L} P L_{1-\alpha / 2}$.

\section{Index Water Yield and Flow}

In developing a regression equation for estimating the (square root of) index water yield, a linear relation was assumed between the index flow and corresponding drainage area. In particular, the drainage area raised to the first power was assumed to be proportional to flow.

Two tests were done to evaluate the plausibility of this assumption. In the first test for unbiasedness, the estimated index flow was computed as $\hat{I} Q_{50}=\hat{I} Y_{50} \cdot D A$ and a residual series as $\xi_{1}=\tilde{I} Q_{50}-\hat{I} Q_{50}$. Because $\xi_{1}$ was not normally distributed, the nonparametric two-sided sign test (Conover, 1980) was applied under the null hypothesis that the median residual $\xi_{1}$ did not differ significantly from zero. The resulting $p$-value was 0.4095 , providing no statistical evidence to reject $\hat{I} Q_{50}$ as an unbiased estimator.

Secondly, the unbiasedness of $\hat{I} Q_{50}$ and the linearity of relation between drainage area and the index flow were tested. In this case, the form of the model evaluated was

$$
\tilde{I} Q_{50}=\beta_{0}+\hat{I} Y_{50} \cdot D A^{\beta_{1}}+\xi_{2}
$$

where it is assumed that the estimated value of $\beta_{0}, \hat{\beta}_{0}$, was not significantly different from zero and that the estimated value of $\beta_{1}, \hat{\beta}_{1}$, was not significantly different from 1 . Nonlinear estimation of the above equation resulted in parameter estimates of $\hat{\beta}_{0}=-2.2913$ with an approximate standard error of $\check{s}_{\hat{\beta}_{0}}=5.8644$ and $\hat{\beta}_{1}=1.0093$ with an approximate standard error of $\check{s}_{\hat{\beta}_{1}}=0.00322$. Again, because $\xi_{2}$ was not normally distributed, the conventional interpretation that rejection of the null hypothesis at a probability level $\alpha$ required that the interval $\left[\hat{\beta}_{0}-t_{1-\alpha / 2.147-9} \cdot \breve{s}_{\hat{\beta}_{0}}, \hat{\beta}_{0}+t_{1-\alpha / 2.147-9} \cdot \check{s}_{\hat{\beta}_{0}}\right]$ not include zero and the interval $\left[\hat{\beta}_{1}-t_{1-\alpha / 2.147-9} \cdot \breve{s}_{\hat{\beta}_{1}}, \hat{\beta}_{1}+t_{1-\alpha / 2.147-9} \cdot \breve{s}_{\hat{\beta}_{1}}\right]$ not include 1 could not be strictly applied. The value of $t_{1-\alpha / 2,147-9}$ indicates the inverse of the Student's $t$ cumulative distribution function with a specified probability level $\alpha$, commonly 0.05 , and degrees of freedom 147-9, reflecting the total number of observations used to develop the regression equation and the total number of parameters used in estimating the square root of the yield and the relation between the yield and flow. These intervals provide no evidence, however, to indicate that $\hat{\beta}_{0}$ is statistically different from 0 or that $\hat{\beta}_{1}$ differs substantially (more than 1 percent) from its hypothesized value of 1 . The approximate correlation between $\hat{\beta}_{0}$ and $\hat{\beta}_{1}$ was -0.4202 , which does not indicate significant ambiguity between the two parameter estimates. Other nonlinear models investigated, including $\tilde{I} Q_{50}=\beta_{0} \cdot \hat{I} Y_{50} \cdot D A^{\beta_{1}}+\xi_{3}$ and $\tilde{I} Q_{50}=\beta_{0}+\beta_{1} \cdot \hat{I} Y_{50} \cdot D A^{\beta_{2}}+\xi_{4}$, resulted in one or more parameters having negative correlations less than -0.997 , making the interpretations of individual parameter estimates unreliable. Therefore, $\hat{I} Q_{50}$ is considered an unbiased and physically plausible estimator of $I Q_{50}$.

\section{Comparison of Index Flows}

Index flows indicated by analysis of gaging-station records $\tilde{I} Q_{50}$ and computed on the basis of the statewide regression equation $\hat{I} Q_{50}$ were compared for 147 streamflowgaging stations used in the development of the regression model. The resulting Spearman (rank) correlation was 0.97, and the corresponding coefficient of determination $R_{S}^{2}$ was 0.9351. Although data for the two sites where index flows determined on the basis of streamflow-gaging station records equaled zero could not be displayed, a logarithmic plot of the measured and computed index flows shows a close match about the line of agreement (fig. 16).

\section{Example Computation}

Following is an example computation to illustrate the procedure for estimating the index flow and computing the corresponding estimation interval. Station 04035000 is used to illustrate the computation. From table 1-2 Appendix 1, the explanatory variables for station 04035000 are $L \_T r a n s$ $=27.0$ percent, $H \_$Trans $=23.9$ percent, Forest $=89.0$ percent, Precip $=32.2$ in., A_Soils $=14.0$ percent, and $D \_S o i l s=47.0$ percent.

As an alternative to the matrix notation $x_{0} \cdot \beta_{\text {ols }}$ used previously, the regression equation for predicting the water yield response can be written as

$$
\begin{aligned}
R \hat{I} Y_{50}=\beta_{0}+\beta_{1} \cdot L \_ \text {Trans }+\beta_{2} \cdot H \_ \text {Trans }+\beta_{3} \cdot \text { Forest }+\beta_{4} \cdot \text { Precip } \\
+\beta_{5} \cdot A \_ \text {Soils }+\beta_{6} \cdot D \_ \text {Soils }
\end{aligned}
$$

Substituting the ordinary least square parameter estimates from table 4 for the beta coefficients and values of the explanatory variables for station 04035000 , the regression equation can be written

$$
\begin{aligned}
R \hat{I} Y_{50}=- & 0.54198+(-0.0013626 \cdot 27.0)+(0.0020480 \cdot 23.9)+ \\
& (0.0040219 \cdot 89.0)+\cdots+(0.023642 \cdot 32.2)+ \\
& (0.0022554 \cdot 14.0)+(0.0016211 \cdot 47.0)
\end{aligned}
$$

At station 04035000 , the drainage area is $273 \mathrm{mi}^{2}$, so the estimate of index flow, $\hat{I} Q_{50}=R \hat{I} Y_{50}^{2} \cdot D A=0.6972^{2} \cdot 273=$ $132.7 \mathrm{ft}^{3} / \mathrm{s}$, in this case compares closely with the measured value of $\tilde{I} Q_{50}=134 \mathrm{ft}^{3} / \mathrm{s}$. 


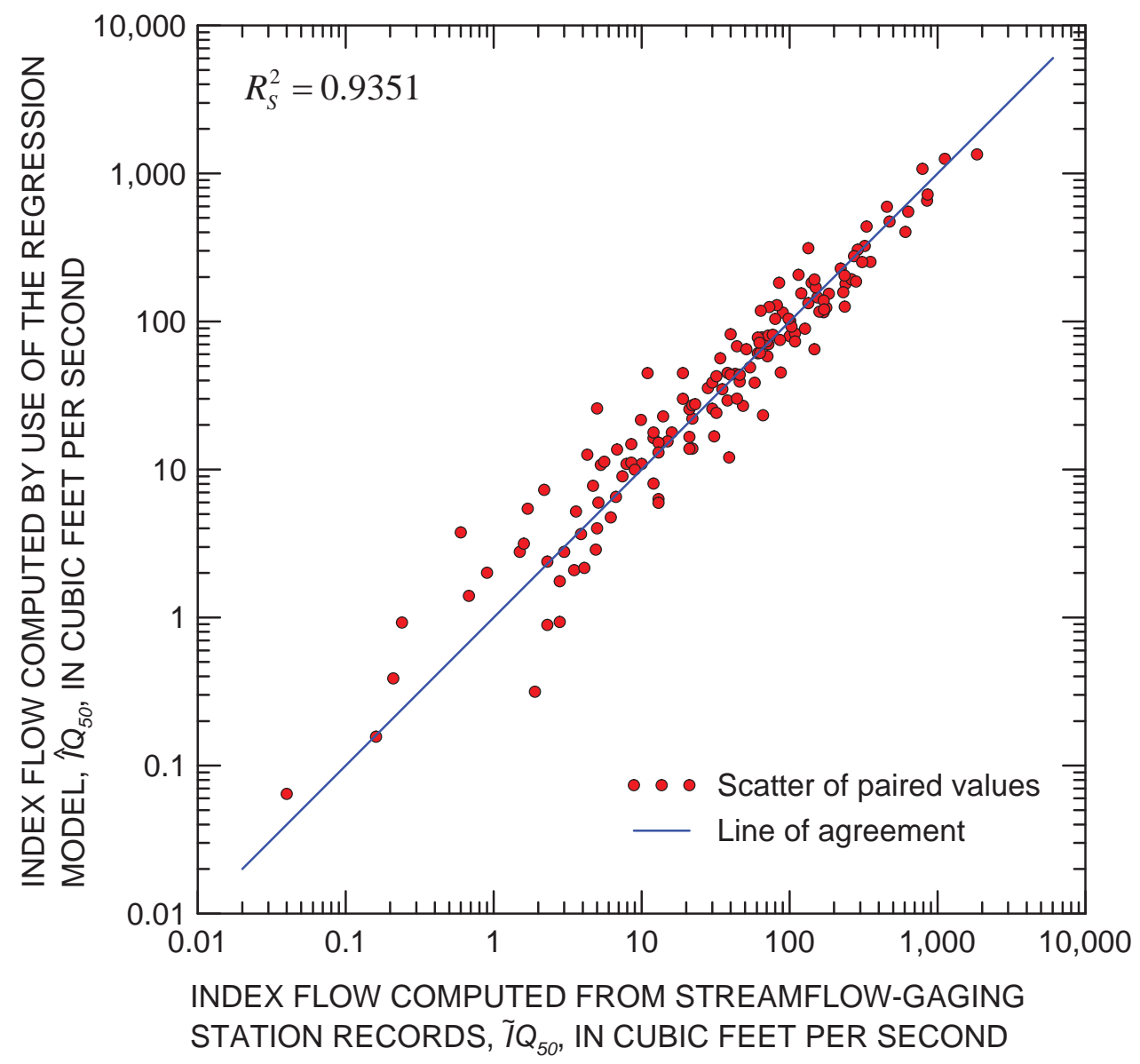

Figure 16. Relation between measured and computed index flows for selected streamflowgaging stations in Michigan $\left[R_{S}^{2}\right.$, the Spearman coefficient of determination].

The interval formed by the range of the lower and upper prediction limits is a measure of the uncertainty of the hydrologic response estimate. In particular, the prediction interval is likely to contain $I Q_{50}$ with probability 1 minus alpha $(1-\alpha)$. The interval width will be smaller for a basin whose hydrologic characteristics are similar to those used to develop the regression than for basins whose characteristics are dissimilar.

The computation of a lower estimation limit about $R I Y_{50}$ for $\alpha=0.2$ will be shown with data from the site 04035000 , as above. With this alpha value, the lower prediction limit will be less than $I Q_{50}$ at a new site about 90 percent of the time. The lower prediction limit is computed as

$$
L P L_{\alpha / 2}=x_{0} \cdot \beta_{\text {ols }}-t_{140,1-0.2 / 2} \cdot \sqrt{s^{2}\left(1+x_{0}\left(X^{\prime} X\right)^{-1} x_{0}^{\prime}\right)}
$$

where $t_{140,1-0.2 / 2}=1.2876, s^{2}=M S_{E}=0.015320$, and $\left(X^{\prime} X\right)^{-1}$ is from the entries in table 5 , results in a lower 90 -percent prediction limit of 0.5328 . Similar computations resulted in an upper prediction limit of 0.8615 for $R \hat{I} Y_{50}$. The 90-percent prediction interval about $R \hat{I} Y_{50}$ corresponds to a 90-percent prediction interval about $\hat{I} Q_{50}$ of $\left[0.5238^{2} \cdot 273.2,0.8615^{2}\right.$ $\cdot 273.2]$. Thus, the probability that $I Q_{50}$ is contained within the estimation interval from $[77.5,202.6] \mathrm{ft}^{3} / \mathrm{s}$ is 80 percent, or $\operatorname{Prob}\left[77.5<I Q_{50}<202.6\right]=0.8$.

\section{Summary}

In 2006, Michigan enacted legislation to prevent new large-capacity withdrawals from causing an adverse impact on a stream's ability to support characteristic fish populations. The median streamflow for the summer month of lowest flow was selected as the index flow against which possible withdrawals would be assessed. This report describes a method to predict the index flow at ungaged stream sites in Michigan. This study was conducted by the U.S. Geological Survey (USGS) in cooperation with the Michigan Department of Environmental Quality and the Michigan Department of Natural Resources.

A set of 147 USGS continuous streamflow-gaging stations were selected from among stations operated in Michi- 
Table 5. The inverse of the $X^{\prime} X$ matrix needed to compute prediction limits.

[Intercept refers to a leading column of ones in the design matrix; L_Trans refers to the percentage of the basin classified as having low ground-water transmissivity; $H \_$Trans refers to the percentage of the basin classified as having high ground-water transmissivity; Forest refers to the percentage of the basin where land cover is classified as forest; Precip refers to the normal annual precipitation for the period 1971-2000, in inches; and A_Soils and D_Soils refer to the percentage of the basin classified in the A and D hydrologic soil groups, respectively]

\begin{tabular}{|c|c|c|c|c|c|c|}
\hline \multicolumn{7}{|c|}{ Explanatory variables in the regression model } \\
\hline Intercept & L_Trans & H_Trans & Forest & Precip & A_Soils & D_Soils \\
\hline $2.38035 \mathrm{E}+00$ & $-8.42611 \mathrm{E}-04$ & $1.43560 \mathrm{E}-03$ & 7.23794E-04 & $-7.11625 E-02$ & $-3.54982 \mathrm{E}-03$ & $-3.50692 \mathrm{E}-03$ \\
\hline$-8.42611 \mathrm{E}-04$ & $1.90162 \mathrm{E}-05$ & 9.13204E-06 & $-1.04607 \mathrm{E}-06$ & 8.79202E-06 & $-2.67491 \mathrm{E}-06$ & $-9.25476 \mathrm{E}-07$ \\
\hline $1.43560 \mathrm{E}-03$ & 9.13204E-06 & $1.70298 \mathrm{E}-05$ & 4.69128E-06 & $-6.03695 E-05$ & $-1.60371 \mathrm{E}-05$ & $-8.67801 \mathrm{E}-06$ \\
\hline 7.23794E-04 & $-1.04607 \mathrm{E}-06$ & 4.69128E-06 & $1.93996 \mathrm{E}-05$ & $-2.49764 \mathrm{E}-05$ & $-1.74926 \mathrm{E}-05$ & $-2.33578 \mathrm{E}-05$ \\
\hline$-7.11625 \mathrm{E}-02$ & 8.79202E-06 & $-6.03695 \mathrm{E}-05$ & $-2.49764 \mathrm{E}-05$ & 2.17903E-03 & $1.09528 \mathrm{E}-04$ & $8.13390 \mathrm{E}-05$ \\
\hline$-3.54982 \mathrm{E}-03$ & $-2.67491 \mathrm{E}-06$ & $-1.60371 \mathrm{E}-05$ & $-1.74926 \mathrm{E}-05$ & $1.09528 \mathrm{E}-04$ & 3.85354E-05 & 2.70690E-05 \\
\hline$-3.50692 \mathrm{E}-03$ & $-9.25476 \mathrm{E}-07$ & $-8.67801 \mathrm{E}-06$ & $-2.33578 \mathrm{E}-05$ & 8.13390E-05 & $2.70690 \mathrm{E}-05$ & 8.42089E-05 \\
\hline
\end{tabular}

gan for 10 or more years that were thought to represent the natural response of streamflow to precipitation. In particular, stations where median low flows were thought to have been appreciably affected by regulation or water withdrawals, augmentations, or diversions were excluded from the regression analysis. Of the 147 selected stations, minimum median flows occurred in July at 5 stations, in August at 92 stations, and in September at 50 stations. Index flows ranged from 0 to $1,850 \mathrm{ft}^{3} / \mathrm{s}$. Index water yields, which were computed by dividing index flows by the corresponding drainage areas upstream from the stream measurement sites, ranged from 0 to 1.309 $\mathrm{ft}^{3} / \mathrm{s}-\mathrm{mi}^{2}$. A square-root transformation was applied to the index water yields so that the transformed values were approximately normally distributed.

A multiple linear regression equation was developed to predict the square root of the index water yield at ungaged sites using selected basin and climatic characteristics as explanatory variables. Selected variables included percentages of land area underlain by low and high aquifer transmissivity, percentage of forest cover, normal annual precipitation, and percentages of land cover associated with hydrologic soil groups A and D (highly and poorly permeable soils, respectively). The regression model explains about 70.8 percent of the variability in the hydrologic response variable, which was the square root of the index water yield. No spatial bias in the regression estimates was detected among seven hydrologic subregions spanning Michigan. Therefore, the single regression equation developed in this report is appropriate for statewide application.
Index flows can be predicted at ungaged sites by squaring the predicted regression response and multiplying the result by the corresponding drainage area. The predicted index flow explains about 94.0 percent of the variability in index flows indicated by streamflow-gaging-station records. In addition, the report documents the technique and provides information needed to compute an interval about the predicted index flow. An example computation is provided.

\section{Acknowledgments}

The authors appreciate the valuable technical contributions the following individuals made in developing the regression model: Jon W. Allan, Manager, and Scott F. DeBoe, Senior Environmental Planner, Consumers Energy Company;

Paul Seelbach, Research Director, Michigan Department of Natural Resources; and Howard W. Reeves, Research Hydrologist, U.S. Geological Survey. Arthur Cooper, Research Assistant, University of Michigan, did the GIS analysis needed to characterize the explanatory variables at the selected streamflow-gaging stations. 


\section{References Cited}

Anderson, J.R., Hardy, E.E., Roach, J.T., and Witmer, R.E., 1976, A land use and land cover classification system for use with remote sensor data: U.S. Geological Survey Professional Paper 964, 41 p., accessed October 3, 2007, at http://landcover.usgs.gov/pdf/anderson.pdf

Conover, W.J., 1980, Practical nonparametric statistics (2d ed.): New York, Wiley, 493 p.

Burley, T.M., 1961, Land use or land utilization?: Professional Geographer, v. 13, no. 6, p. 18-20.

Clawson, Marion, and Stewart, C.L., 1965, Land use information-A critical survey of U.S. statistics including possibilities for greater uniformity: Baltimore, Md., Johns Hopkins Press for Resources for the Future, Inc., 402 p.

Holtschlag, D.J., and Croskey, H.M., 1984, Statistical models for estimating flow characteristics of Michigan streams: U.S. Geological Survey Water-Resources Investigations Report 84-4207, 80 p.

Draper, N.R., and Smith, Harry, 1966, Applied regression analysis: New York, Wiley, 407 p.

Knutilla, R.L., 1967, Flow characteristics of Michigan streams: U.S. Geological Survey Open-File Report 67-135, 55 p.

Michigan Climatological Resources Program, 2004, Michigan climatological normals, 1971-2000: East Lansing, Mich., State Climatologist's Office, Michigan State University, digital media.

Michigan Department of Environmental Quality [n.d.], Calculating curve numbers using GIS: Hydrologic Studies Unit, 10 p., accessed Oct. 3, 2007, at http://www.michigan.gov/ documents/deq/lwm-cn-calc-using-gis_202628_7.pdf

Michigan Department of Information Technology, 2005a, Glacial deposits estimated transmissivity geographic theme: Lansing, Mich., Center for Geographic Information, accessed December 6, 2007, at http://www.mcgi.state.mi.us/ $m g d l / ? r e l=$ ext\&action $=$ sext

Michigan Department of Information Technology, 2005b, Michigan glacial landsystems coverage by D.P. Lusch: East Lansing, Michigan, Michigan State University, accessed on December 6, 2007, at http://www.mcgi.state.mi.us/ $m g d l / ?$ rel $=$ ext\&action $=$ sext
Michigan Library, 2006, Michigan in Brief-Information about the state of Michigan: Lansing, Mich., accessed December 6, 2007, at www.michigan.gov/hal/0,1607,7-1601548120826 20829-56001--,00.html

Michigan Legislature, 2006, Public Acts of 2006, Act No. 33: 93rd Legislature, Regular Session of 2006, accessed September 27, 2007, at http://www.legislature.mi.gov/ documents/2005-2006/publicact/pdf/2006-PA-0033.pdf

Michigan Resource Information System, 1978, MIRIS Landuse/cover Polygon-Geographic data and metadata: Lansing, Michi., Michigan Department of Natural Resources, accessed December 6, 2007, at http://www.mcgi.state.mi.us/ $m g d l /$

Natural Resources Conservation Service, 2004, Estimation of direct runoff from storm rainfall, Chapter 10 of Part 630, Hydrology, of National engineering handbook: Accessed December 7, 2007, at http://policy.nrcs.usda.gov/medial pdf/H_210_630_10.pdf

Natural Resources Conservation Service, 2007, Hydrologic soil groups, Chapter 7 of Part 630, Hydrology of National engineering handbook: Accessed December 6, 2007, at http://policy.nrcs.usda.gov/media/pdf/H_210_630_7.pdf

Neff, B.P., Day, S.M., Piggott, A.R., and Fuller, L.M., Base flow in the Great Lakes Basin: U.S. Geological Survey Scientific Investigations Report 2005-5217, 23 p.

Poeter, E.P., Hill, M.C., Banta, E.R., Mehl, Steffen, and Christensen, Steen, 2005, UCODE_2005 and six other computer codes for universal sensitivity analysis, calibration, and uncertainty evaluation: U.S. Geological Survey Techniques and Methods 6-A11, 283 p.

Seaber, P.R., Kapinos, F.P., and Knapp, G.L., 1987, Hydrologic unit maps: U.S. Geological Survey Water-Supply Paper 2294, 63 p., accessed December 7, 2007, at http:// pubs.usgs.gov/wsp/wsp2294/

U.S. Census Bureau, 2007, State \& county QuickFacts, accessed December 6, 2007, at http://quickfacts.census.gov/ qfd/states/26000.html 


\section{Appendix 1. Tables of streamflow-gaging station attributes, flow characteristics, and explanatory variables used in the development of the regression equation for estimating the index flow at ungaged streams in Michigan}




\begin{tabular}{|c|c|c|c|c|c|c|c|c|c|}
\hline $\begin{array}{c}\text { U.S. } \\
\text { Geological } \\
\text { Survey } \\
\text { station } \\
\text { number }\end{array}$ & Station name & $\begin{array}{l}\text { Latitude } \\
\text { (decimal } \\
\text { degrees) }\end{array}$ & $\begin{array}{l}\text { Longitude } \\
\text { (decimal } \\
\text { degrees) }\end{array}$ & $\begin{array}{l}\text { Drainage } \\
\text { area } \\
\text { (square } \\
\text { miles) }\end{array}$ & $\begin{array}{l}\text { Minimum } \\
\text { monthly } \\
\text { median flow } \\
\text { (cubic feet } \\
\text { per second) } \\
\left(I Q_{50}\right)\end{array}$ & $\begin{array}{c}\text { Minimum } \\
\text { monthly median } \\
\text { yield (cubic feet } \\
\text { per second per } \\
\text { square mile) } \\
\left(I Y_{50}\right)\end{array}$ & $\begin{array}{c}\text { Month of } \\
\text { minimum } \\
\text { flow }\end{array}$ & $\begin{array}{l}\text { Years } \\
\text { of } \\
\text { record }\end{array}$ & $\begin{array}{c}\text { Water years } \\
\text { included in } \\
\text { analyses }\end{array}$ \\
\hline 04001000 & Washington Creek at Windigo, Mich. & 47.92306 & 89.14500 & 13.2 & 2.3 & 0.17424 & August & 39 & 1965-2003 \\
\hline 04031000 & Black River near Bessemer, Mich. & 46.51134 & 90.07462 & 200 & 40.0 & 0.20000 & August & 33 & $\begin{array}{l}1955-1982 \\
2001-2005\end{array}$ \\
\hline 04031500 & Presque Isle River at Marenisco, Mich. & 46.37217 & 89.69238 & 172 & 71.0 & 0.41183 & August & 38 & 1945-1982 \\
\hline 04032000 & Presque Isle River near Tula, Mich. & 46.54689 & 89.77738 & 264 & 90.0 & 0.34078 & August & 29 & 1945-1973 \\
\hline 04033000 & $\begin{array}{l}\text { Middle Branch Ontonagon River near Pauld- } \\
\text { ing, Mich. }\end{array}$ & 46.35689 & 89.07736 & 162 & 100 & 0.61843 & August & 59 & $\begin{array}{r}\text { 1943-1995, } \\
2001-2005\end{array}$ \\
\hline 04035000 & East Br Ontonagon River near Mass, Mich. & 46.68994 & 89.07347 & 273 & 134 & 0.49048 & August & 38 & 1942-1979 \\
\hline 04040000 & Ontonagon River near Rockland, Mich & 46.72077 & 89.20709 & 1330 & 634 & 0.47530 & August & 64 & 1942-2005 \\
\hline 04040500 & Sturgeon River near Sidnaw, Mich. & 46.58411 & 88.57597 & 169 & 44.0 & 0.26036 & August & 66 & $\begin{array}{r}\text { 1913-1915, } \\
1943-2005\end{array}$ \\
\hline 04041500 & Sturgeon River near Alston, Mich. & 46.72632 & 88.66208 & 343 & 184 & 0.53629 & August & 72 & $\begin{array}{r}1932-1940 \\
1943-2005\end{array}$ \\
\hline 04043050 & Trap Rock River near Lake Linden, Mich. & 47.22854 & 88.38539 & 29.6 & 13.0 & 0.43919 & August & 39 & 1967-2005 \\
\hline 04045500 & Tahquamenon River near Paradise, Mich. & 46.57501 & 85.26955 & 757 & 321 & 0.42410 & August & 52 & 1954-2005 \\
\hline 04046000 & Black River near Garnet, Mich. & 46.11806 & 85.36537 & 33.5 & 10.0 & 0.29851 & August & 38 & $\begin{array}{r}\text { 1952-1978, } \\
1995-2005\end{array}$ \\
\hline 04049500 & Manistique River at Germfask, Mich. & 46.23331 & 85.92791 & 420 & 238 & 0.56721 & August & 33 & 1938-1970 \\
\hline 04055000 & Manistique River near Blaney, Mich. & 46.08609 & 86.05930 & 716 & 352 & 0.49183 & August & 33 & 1938-1970 \\
\hline 04056000 & $\begin{array}{l}\text { West Branch Manistique River near Manis- } \\
\text { tique, Mich. }\end{array}$ & 46.08886 & 86.16125 & 326 & 154 & 0.47312 & August & 19 & 1938-1956 \\
\hline 04056500 & Manistique River near Manistique, Mich. & 46.03053 & 86.16125 & 1,130 & 605 & 0.53716 & August & 68 & 1938-2005 \\
\hline 04057510 & Sturgeon River near Nahma Junction, Mich. & 45.94302 & 86.70570 & 184 & 82.0 & 0.44662 & August & 39 & 1967-2005 \\
\hline 04057800 & $\begin{array}{l}\text { Middle Branch Escanaba River at Humboldt, } \\
\text { Mich. }\end{array}$ & 46.49910 & 87.88652 & 45.7 & 16.0 & 0.35011 & August & 47 & 1959-2005 \\
\hline 04058000 & M Br Escanaba River near Ishpeming, Mich. & 46.39438 & 87.75847 & 128 & 43.0 & 0.33515 & August & 22 & 1954-1975 \\
\hline 04058400 & Goose Lake Outlet near Sands Station, Mich. & 46.39300 & 87.49375 & 36.3 & 12.0 & 0.33058 & August & 17 & 1966-1982 \\
\hline
\end{tabular}


Table 1-1. Flow, yield, and record characteristics for streamflow-gaging stations used in the regression analysis-Continued.

[A water year is the 12-month period from October 1 to September 30. The water year is designated by the calendar year in which it ends]

\begin{tabular}{|c|c|c|c|c|c|c|c|c|c|}
\hline $\begin{array}{c}\text { U.S. } \\
\text { Geological } \\
\text { Survey } \\
\text { station } \\
\text { number }\end{array}$ & Station name & $\begin{array}{l}\text { Latitude } \\
\text { (decimal } \\
\text { degrees) }\end{array}$ & $\begin{array}{l}\text { Longitude } \\
\text { (decimal } \\
\text { degrees) }\end{array}$ & $\begin{array}{l}\text { Drainage } \\
\text { area } \\
\text { (square } \\
\text { miles) }\end{array}$ & $\begin{array}{l}\text { Minimum } \\
\text { monthly } \\
\text { median flow } \\
\text { (cubic feet } \\
\text { per second) } \\
\left(I Q_{50}\right)\end{array}$ & $\begin{array}{c}\text { Minimum } \\
\text { monthly median } \\
\text { yield (cubic feet } \\
\text { per second per } \\
\text { square mile) } \\
\left(I Y_{50}\right)\end{array}$ & $\begin{array}{l}\text { Month of } \\
\text { minimum } \\
\text { flow }\end{array}$ & $\begin{array}{l}\text { Years } \\
\text { of } \\
\text { record }\end{array}$ & $\begin{array}{c}\text { Water years } \\
\text { included in } \\
\text { analyses }\end{array}$ \\
\hline 04059000 & Escanaba River at Cornell, Mich. & 45.90857 & 87.21375 & 871 & 330 & 0.37892 & August & 55 & $1951-2005$ \\
\hline 04059500 & Ford River near Hyde, Mich. & 45.75552 & 87.20152 & 444 & 85.0 & 0.19140 & August & 51 & 1955-2005 \\
\hline 04060993 & Brule River near Florence, Wisc. & 45.96079 & 88.31597 & 378 & 236 & 0.62269 & August & 62 & 1944-2005 \\
\hline 04061500 & Paint River at Crystal Falls, Mich. & 46.10578 & 88.33486 & 600 & 288 & 0.47976 & August & 52 & 1945-1996 \\
\hline 04062200 & Peshekee River near Champion, Mich. & 46.55688 & 88.00263 & 132 & 28.0 & 0.21244 & August & 23 & $\begin{array}{l}\text { 1961-1978, } \\
2001-2005\end{array}$ \\
\hline 04096015 & Galien River near Sawyer, Mich. & 41.87365 & 86.57502 & 80.8 & 21.0 & 0.25990 & September & 11 & $1995-2005$ \\
\hline 04096405 & St. Joseph River at Burlington, Mich. & 42.10282 & 85.04025 & 201 & 61.0 & 0.30348 & September & 43 & $1963-2005$ \\
\hline 04096515 & South Branch Hog Creek near Allen, Mich. & 41.94866 & 84.82774 & 48.7 & 7.9 & 0.16222 & September & 36 & $1970-2005$ \\
\hline 04096600 & Coldwater River near Hodunk, Mich. & 42.02921 & 85.10692 & 286 & 65.0 & 0.22759 & September & 27 & 1963-1989 \\
\hline 04096900 & Nottawa Creek near Athens, Mich. & 42.05560 & 85.30832 & 162 & 72.0 & 0.44444 & September & 31 & 1967-1997 \\
\hline 04097170 & Portage River near Vicksburg, Mich. & 42.11477 & 85.48555 & 68.2 & 30.0 & 0.43988 & September & 21 & $\begin{array}{r}\text { 1946-1951, } \\
1965-1979\end{array}$ \\
\hline 04097540 & Prairie River near Nottawa, Mich. & 41.88838 & 85.40943 & 107 & 46.0 & 0.43152 & September & 43 & $1963-2005$ \\
\hline 04099000 & St. Joseph River at Mottville, Mich. & 41.80088 & 85.75610 & 1,880 & 850 & 0.45227 & September & 82 & $1924-2005$ \\
\hline 04101500 & St. Joseph River at Niles, Mich. & 41.82921 & 86.25973 & 3,670 & 1,850 & 0.50464 & September & 75 & $1931-2005$ \\
\hline 04101800 & Dowagiac River at Sumnerville, Mich. & 41.91338 & 86.21307 & 252 & 177 & 0.70378 & August & 45 & $1961-2005$ \\
\hline 04102500 & Paw Paw River at Riverside, Mich. & 42.18615 & 86.36836 & 390 & 262 & 0.67197 & August & 54 & $1952-2005$ \\
\hline 04102700 & $\begin{array}{l}\text { South Branch Black River near Bangor, } \\
\text { Mich. }\end{array}$ & 42.35420 & 86.18753 & 83.5 & 35.0 & 0.41916 & September & 40 & $1966-2005$ \\
\hline 04103010 & Kalamazoo River near Marengo, Mich. & 42.26171 & 84.85581 & 270 & 147 & 0.54545 & September & 19 & $1987-2005$ \\
\hline 04104945 & Wanadoga Creek near Battle Creek, Mich. & 42.39643 & 85.13166 & 48.3 & 15.0 & 0.31056 & August & 11 & 1995-2005 \\
\hline 04105000 & Battle Creek at Battle Creek, Mich. & 42.33199 & 85.15416 & 274 & 70.0 & 0.25547 & September & 72 & $1934-2005$ \\
\hline 04105700 & Augusta Creek near Augusta, Mich. & 42.35337 & 85.35389 & 36.8 & 31.0 & 0.84239 & August & 41 & 1965-2005 \\
\hline 04108600 & Rabbit River near Hopkins, Mich. & 42.64225 & 85.72197 & 65.1 & 22.0 & 0.33794 & September & 40 & 1966-2005 \\
\hline 04108801 & Macatawa River near Zeeland, Mich. & 42.77919 & 86.01837 & 66.9 & 4.3 & 0.06428 & September & 45 & $1961-2005$ \\
\hline
\end{tabular}




\begin{tabular}{|c|c|c|c|c|c|c|c|c|c|}
\hline $\begin{array}{c}\text { U.S. } \\
\text { Geological } \\
\text { Survey } \\
\text { station } \\
\text { number }\end{array}$ & Station name & $\begin{array}{l}\text { Latitude } \\
\text { (decimal } \\
\text { degrees) }\end{array}$ & $\begin{array}{c}\text { Longitude } \\
\text { (decimal } \\
\text { degrees) }\end{array}$ & $\begin{array}{l}\text { Drainage } \\
\text { area } \\
\text { (square } \\
\text { miles) }\end{array}$ & $\begin{array}{l}\text { Minimum } \\
\text { monthly } \\
\text { median flow } \\
\text { (cubic feet } \\
\text { per second) } \\
\left(I Q_{50}\right)\end{array}$ & $\begin{array}{c}\text { Minimum } \\
\text { monthly median } \\
\text { yield (cubic feet } \\
\text { per second per } \\
\text { square mile) } \\
\left(I Y_{50}\right)\end{array}$ & $\begin{array}{l}\text { Month of } \\
\text { minimum } \\
\text { flow }\end{array}$ & $\begin{array}{l}\text { Years } \\
\text { of } \\
\text { record }\end{array}$ & $\begin{array}{c}\text { Water years } \\
\text { included in } \\
\text { analyses }\end{array}$ \\
\hline 04110000 & Orchard Creek at Munith, Mich. & 42.39365 & 84.26496 & 47.3 & 5.3 & 0.11205 & September & 13 & 1944-1956 \\
\hline 04111500 & Deer Creek near Dansville, Mich. & 42.60837 & 84.32080 & 16.3 & 0.9 & 0.05521 & September & 52 & 1954-2005 \\
\hline 04112000 & Sloan Creek near Williamston, Mich. & 42.67587 & 84.36386 & 10.4 & 0.2 & 0.02308 & September & 52 & 1954-2005 \\
\hline 04112500 & Red Cedar River at East Lansing, Mich. & 42.72781 & 84.47775 & 344 & 38.0 & 0.11047 & September & 77 & $\begin{array}{l}\text { 1902-1903, } \\
1931-2005\end{array}$ \\
\hline 04114498 & Looking Glass River near Eagle, Mich. & 42.82809 & 84.75943 & 284 & 40.0 & 0.14080 & September & 57 & $\begin{array}{l}1944-1996, \\
2002-2005\end{array}$ \\
\hline 04115000 & Maple River at Maple Rapids, Mich. & 43.10975 & 84.69305 & 420 & 30.0 & 0.07141 & September & 62 & 1944-2005 \\
\hline 04116500 & Flat River at Smyrna, Mich. & 43.05281 & 85.26474 & 516 & 222 & 0.42998 & August & 36 & 1951-1986 \\
\hline 04117000 & Quaker Brook near Nashville, Mich. & 42.56587 & 85.09361 & 7.8 & 2.8 & 0.35897 & September & 33 & $\begin{array}{r}1954-1975, \\
1995-2005\end{array}$ \\
\hline 04117500 & Thornapple River near Hastings, Mich. & 42.61587 & 85.23639 & 410 & 109 & 0.26553 & September & 61 & 1945-2005 \\
\hline 04118000 & Thornapple River near Caledonia, Mich. & 42.81114 & 85.48335 & 795 & 281 & 0.35337 & September & 41 & $\begin{array}{l}\text { 1952-1981, } \\
1984-1994\end{array}$ \\
\hline 04118500 & Rogue River near Rockford, Mich. & 43.08225 & 85.59086 & 257 & 127 & 0.49378 & September & 50 & $\begin{array}{r}1952-1982, \\
1988-2005\end{array}$ \\
\hline 04121000 & Muskegon River near Merritt, Mich. & 44.33557 & 84.89003 & 352 & 115 & 0.32689 & August & 27 & $1947-1973$ \\
\hline 04121300 & Clam River at Vogel Center, Mich. & 44.20057 & 85.05281 & 239 & 73.0 & 0.30506 & August & 40 & 1966-2005 \\
\hline 04121900 & Little Muskegon River near Morley, Mich. & 43.50253 & 85.34254 & 136 & 72.0 & 0.53137 & July & 30 & 1967-1996 \\
\hline 04122100 & Bear Creek near Muskegon, Mich. & 43.28863 & 86.22284 & 16.7 & 5.0 & 0.29940 & August & 40 & 1966-2005 \\
\hline 04122200 & White River near Whitehall, Mich. & 43.46418 & 86.23257 & 404 & 273 & 0.67491 & August & 49 & 1957-2005 \\
\hline 04122500 & Pere Marquette River at Scottville, Mich. & 43.94501 & 86.27869 & 689 & 455 & 0.65999 & August & 67 & 1939-2005 \\
\hline 04123000 & Big Sable River near Freesoil, Mich. & 44.12028 & 86.28008 & 115 & 101 & 0.87826 & August & 32 & $1942-1973$ \\
\hline 04123500 & Manistee River near Grayling, Mich. & 44.69307 & 84.84726 & 132 & 170 & 1.28496 & August & 31 & $1943-1973$ \\
\hline 04124000 & Manistee River near Sherman, Mich. & 44.43639 & 85.69868 & 865 & 856 & 0.98971 & August & 86 & $\begin{array}{l}\text { 1903-1916, } \\
1934-2005\end{array}$ \\
\hline
\end{tabular}


Table 1-1. Flow, yield, and record characteristics for streamflow-gaging stations used in the regression analysis-Continued.

[A water year is the 12-month period from October 1 to September 30. The water year is designated by the calendar year in which it ends]

\begin{tabular}{|c|c|c|c|c|c|c|c|c|c|}
\hline $\begin{array}{c}\text { U.S. } \\
\text { Geological } \\
\text { Survey } \\
\text { station } \\
\text { number }\end{array}$ & Station name & $\begin{array}{l}\text { Latitude } \\
\text { (decimal } \\
\text { degrees) }\end{array}$ & $\begin{array}{l}\text { Longitude } \\
\text { (decimal } \\
\text { degrees) }\end{array}$ & $\begin{array}{l}\text { Drainage } \\
\text { area } \\
\text { (square } \\
\text { miles) }\end{array}$ & $\begin{array}{l}\text { Minimum } \\
\text { monthly } \\
\text { median flow } \\
\text { (cubic feet } \\
\text { per second) } \\
\left(I Q_{50}\right)\end{array}$ & $\begin{array}{c}\text { Minimum } \\
\text { monthly median } \\
\text { yield (cubic feet } \\
\text { per second per } \\
\text { square mile) } \\
\left(I Y_{50}\right)\end{array}$ & $\begin{array}{l}\text { Month of } \\
\text { minimum } \\
\text { flow }\end{array}$ & $\begin{array}{l}\text { Years } \\
\text { of } \\
\text { record }\end{array}$ & $\begin{array}{c}\text { Water years } \\
\text { included in } \\
\text { analyses }\end{array}$ \\
\hline 04124500 & East Branch Pine River near Tustin, Mich. & 44.10251 & 85.51728 & 58.9 & 9.9 & 0.16808 & August & 26 & $\begin{array}{l}\text { 1952-1963, } \\
\text { 1992-2005 }\end{array}$ \\
\hline 04125000 & Pine River near Leroy, Mich. & 44.06279 & 85.54894 & 130 & 51.0 & 0.39140 & August & 12 & $1952-1963$ \\
\hline 04125500 & Pine River near Hoxeyville, Mich. & 44.20306 & 85.79951 & 254 & 230 & 0.90658 & August & 31 & 1952-1982 \\
\hline 04126200 & Little Manistee River near Freesoil, Mich. & 44.18362 & 86.16758 & 185 & 141 & 0.76381 & August & 19 & $1957-1975$ \\
\hline 04127918 & Pine River near Rudyard, Mich. & 46.18585 & 84.59783 & 202 & 77.0 & 0.38138 & August & 34 & 1972-2005 \\
\hline 04127997 & Sturgeon River at Wolverine, Mich. & 45.29890 & 84.61114 & 181 & 170 & 0.93975 & August & 64 & 1942-2005 \\
\hline 04128990 & Pigeon River near Vanderbilt, Mich. & 45.15668 & 84.46669 & 57.7 & 58.0 & 1.00520 & July & 55 & $1951-2005$ \\
\hline 04133501 & $\begin{array}{l}\text { Thunder Bay River at Herron Road near } \\
\text { Bolton, Mich. }\end{array}$ & 45.12446 & 83.64721 & 586 & 309 & 0.52739 & September & 40 & $\begin{array}{l}\text { 1945-1980, } \\
\text { 2002-2005 }\end{array}$ \\
\hline 04135000 & Thunder Bay River near Alpena, Mich. & 45.09418 & 83.49970 & 1,240 & 474 & 0.38288 & August & 22 & $\begin{array}{l}\text { 1901-1908, } \\
1980-1993\end{array}$ \\
\hline 04135500 & Au Sable River at Grayling, Mich. & 44.65974 & 84.71253 & 96.6 & 61.0 & 0.63147 & August & 51 & 1943-1993 \\
\hline 04135600 & $\begin{array}{l}\text { East Branch Au Sable River at Grayling, } \\
\text { Mich. }\end{array}$ & 44.66890 & 84.70558 & 71.2 & 34.0 & 0.47753 & August & 27 & 1958-1984 \\
\hline 04135700 & $\begin{array}{l}\text { South Branch Au Sable River near Luzerne, } \\
\text { Mich. }\end{array}$ & 44.61474 & 84.45557 & 391 & 134 & 0.34236 & August & 38 & $\begin{array}{r}\text { 1967-1989, } \\
1991-2005\end{array}$ \\
\hline 04136500 & Au Sable River at Mio, Mich. & 44.66001 & 84.13112 & 1,360 & 788 & 0.57894 & August & 54 & 1952-2005 \\
\hline 04137500 & Au Sable R near Au Sable, Mich. & 44.43640 & 83.43386 & 1,740 & 1,120 & 0.64383 & September & 19 & $1987-2005$ \\
\hline 04138000 & East Branch Au Gres River at McIvor, Mich. & 44.23252 & 83.70082 & 89.9 & 38.0 & 0.42269 & August & 23 & $1951-1973$ \\
\hline 04138500 & Au Gres River near National City, Mich. & 44.17613 & 83.74248 & 151 & 21.0 & 0.13871 & August & 31 & $1951-1981$ \\
\hline 04139000 & Houghton Creek near Lupton, Mich. & 44.39585 & 84.04722 & 29.8 & 39.0 & 1.30872 & August & 23 & 1950-1972 \\
\hline 04139500 & $\begin{array}{l}\text { Rifle River at "The Ranch" near Lupton, } \\
\text { Mich. }\end{array}$ & 44.39335 & 84.03833 & 57.4 & 66.0 & 1.14983 & August & 22 & 1950-1971 \\
\hline 04140000 & Prior Creek near Selkirk, Mich. & 44.33502 & 84.06833 & 21.0 & 6.7 & 0.31905 & August & 22 & $1951-1972$ \\
\hline 04140500 & Rifle River at Selkirk, Mich. & 44.31335 & 84.06944 & 116 & 87.0 & 0.74742 & August & 32 & 1951-1982 \\
\hline 04141000 & $\begin{array}{l}\text { South Branch Shepards Creek near Selkirk, } \\
\text { Mich. }\end{array}$ & 44.30780 & 84.08694 & 1.1 & 0.0 & 0.03636 & July & 27 & 1952-1978 \\
\hline
\end{tabular}




\begin{tabular}{|c|c|c|c|c|c|c|c|c|c|}
\hline $\begin{array}{c}\text { U.S. } \\
\text { Geological } \\
\text { Survey } \\
\text { station } \\
\text { number }\end{array}$ & Station name & $\begin{array}{l}\text { Latitude } \\
\text { (decimal } \\
\text { degrees) }\end{array}$ & $\begin{array}{c}\text { Longitude } \\
\text { (decimal } \\
\text { degrees) }\end{array}$ & $\begin{array}{c}\text { Drainage } \\
\text { area } \\
\text { (square } \\
\text { miles) }\end{array}$ & $\begin{array}{l}\text { Minimum } \\
\text { monthly } \\
\text { median flow } \\
\text { (cubic feet } \\
\text { per second) } \\
\left(I Q_{50}\right)\end{array}$ & $\begin{array}{l}\text { Minimum } \\
\text { monthly median } \\
\text { yield (cubic feet } \\
\text { per second per } \\
\text { square mile) } \\
\left(I Y_{50}\right)\end{array}$ & $\begin{array}{l}\text { Month of } \\
\text { minimum } \\
\text { flow }\end{array}$ & $\begin{array}{l}\text { Years } \\
\text { of } \\
\text { record }\end{array}$ & $\begin{array}{c}\text { Water years } \\
\text { included in } \\
\text { analyses }\end{array}$ \\
\hline 04141500 & West Branch Rifle River near Selkirk, Mich. & 44.26113 & 84.10916 & 65.4 & 32.0 & 0.48930 & July & 12 & $1952-1963$ \\
\hline 04142000 & Rifle River near Sterling, Mich. & 44.07252 & 84.01999 & 333 & 159 & 0.47791 & August & 69 & $1937-2005$ \\
\hline 04143900 & Shiawassee River at Linden, Mich. & 42.81586 & 83.80190 & 81.9 & 22.0 & 0.26862 & August & 30 & $\begin{array}{l}\text { 1968-1994, } \\
2001-2003\end{array}$ \\
\hline 04144000 & Shiawassee River at Byron, Mich. & 42.82364 & 83.94579 & 363 & 71.0 & 0.19543 & September & 36 & $1948-1983$ \\
\hline 04144500 & Shiawassee River at Owosso, Mich. & 43.01503 & 84.18108 & 530 & 86.0 & 0.16214 & September & 75 & $1931-2005$ \\
\hline 04145500 & Bad River near Brant, Mich. & 43.29669 & 84.22915 & 89.9 & 0.6 & 0.00667 & August & 11 & 1949-1959 \\
\hline 04146000 & Farmers Creek near Lapeer, Mich. & 43.04475 & 83.33717 & 51.1 & 5.1 & 0.09980 & August & 73 & $1933-2005$ \\
\hline 04146063 & $\begin{array}{l}\text { South Branch Flint River near Columbiaville, } \\
\text { Mich. }\end{array}$ & 43.15947 & 83.35078 & 211 & 48.5 & 0.23029 & August & 26 & 1980-2005 \\
\hline 04147500 & Flint River near Otisville, Mich. & 43.11114 & 83.51940 & 526 & 109 & 0.20715 & August & 52 & $\begin{array}{l}\text { 1953-1989, } \\
1991-2005\end{array}$ \\
\hline 04147990 & Butternut Creek near Genesee, Mich. & 43.13586 & 83.59912 & 34.8 & 3.6 & 0.10345 & August & 14 & $1970-1983$ \\
\hline 04148140 & Kearsley Creek near Davison, Mich. & 43.03364 & 83.58134 & 99.7 & 13.0 & 0.13039 & August & 40 & $1966-2005$ \\
\hline 04148160 & Gilkey Creek near Flint, Mich. & 43.02419 & 83.62551 & 6.9 & 0.2 & 0.02319 & August & 14 & $1970-1983$ \\
\hline 04148200 & Swartz Creek near Holly, Mich. & 42.82753 & 83.62828 & 12.1 & 1.5 & 0.12397 & September & 20 & $1956-1975$ \\
\hline 04148300 & Swartz Creek at Flint, Mich. & 42.98781 & 83.73246 & 114 & 5.6 & 0.04904 & August & 14 & $1970-1983$ \\
\hline 04148440 & Thread Creek near Flint, Mich. & 42.97503 & 83.63579 & 54.4 & 4.7 & 0.08640 & August & 14 & $1970-1983$ \\
\hline 04148500 & Flint River near Flint, Mich. & 43.03892 & 83.77163 & 960 & 171 & 0.17805 & August & 73 & $1933-2005$ \\
\hline 04150000 & $\begin{array}{l}\text { South Branch Cass River near Cass City, } \\
\text { Mich. }\end{array}$ & 43.56696 & 83.11189 & 239 & 5.0 & 0.02090 & September & 32 & 1949-1980 \\
\hline 04150500 & Cass River at Cass City, Mich. & 43.58419 & 83.17606 & 363 & 11.0 & 0.03034 & September & 55 & $\begin{array}{l}\text { 1948-1997, } \\
\text { 2001-2005 }\end{array}$ \\
\hline 04151500 & Cass River at Frankenmuth, Mich. & 43.32780 & 83.74802 & 842 & 64.0 & 0.07597 & September & 69 & $\begin{array}{r}\text { 1935-1936, } \\
\text { 1939-2005 }\end{array}$ \\
\hline 04152238 & $\begin{array}{l}\text { South Branch Tobacco River near Beaverton, } \\
\text { Mich. }\end{array}$ & 43.86697 & 84.54529 & 152 & 63.0 & 0.41366 & September & 19 & $1987-2005$ \\
\hline
\end{tabular}


Table 1-1. Flow, yield, and record characteristics for streamflow-gaging stations used in the regression analysis-Continued.

[A water year is the 12-month period from October 1 to September 30. The water year is designated by the calendar year in which it ends]

\begin{tabular}{|c|c|c|c|c|c|c|c|c|c|}
\hline $\begin{array}{c}\text { U.S. } \\
\text { Geological } \\
\text { Survey } \\
\text { station } \\
\text { number }\end{array}$ & Station name & $\begin{array}{l}\text { Latitude } \\
\text { (decimal } \\
\text { degrees) }\end{array}$ & $\begin{array}{l}\text { Longitude } \\
\text { (decimal } \\
\text { degrees) }\end{array}$ & $\begin{array}{l}\text { Drainage } \\
\text { area } \\
\text { (square } \\
\text { miles) }\end{array}$ & $\begin{array}{c}\text { Minimum } \\
\text { monthly } \\
\text { median flow } \\
\text { (cubic feet } \\
\text { per second) } \\
\left(I Q_{50}\right)\end{array}$ & $\begin{array}{c}\text { Minimum } \\
\text { monthly median } \\
\text { yield (cubic feet } \\
\text { per second per } \\
\text { square mile) } \\
\left(I Y_{50}\right)\end{array}$ & $\begin{array}{l}\text { Month of } \\
\text { minimum } \\
\text { flow }\end{array}$ & $\begin{array}{l}\text { Years } \\
\text { of } \\
\text { record }\end{array}$ & $\begin{array}{c}\text { Water years } \\
\text { included in } \\
\text { analyses }\end{array}$ \\
\hline 04153500 & Salt River near North Bradley, Mich. & 43.70281 & 84.47056 & 145 & 8.5 & 0.05874 & August & 38 & $1934-1971$ \\
\hline 04154000 & Chippewa River near Mount Pleasant, Mich. & 43.62558 & 84.70779 & 409 & 150 & 0.36702 & August & 73 & 1933-2005 \\
\hline 04155000 & Pine River at Alma, Mich. & 43.37948 & 84.65556 & 309 & 80.0 & 0.25882 & August & 75 & 1931-2005 \\
\hline 04157500 & State Drain near Sebewaing, Mich. & 43.71196 & 83.42774 & 67.3 & 0 & 0.00000 & August & 15 & 1940-1954 \\
\hline 04158000 & Columbia Drain near Sebewaing, Mich. & 43.72724 & 83.39607 & 33.9 & 0 & 0.00000 & August & 18 & $\begin{array}{r}1940-1954, \\
1988-1990\end{array}$ \\
\hline 04158500 & Pigeon River near Owendale, Mich. & 43.76363 & 83.24606 & 53.3 & 3.0 & 0.05629 & September & 30 & 1953-1982 \\
\hline 04159492 & Black River near Jeddo, Mich. & 43.15253 & 82.62409 & 479 & 22.0 & 0.04589 & September & 62 & 1944-2005 \\
\hline 04159900 & Mill Creek near Avoca, Mich. & 43.05447 & 82.73465 & 169 & 6.8 & 0.04033 & September & 31 & $\begin{array}{l}1963-1975 \\
1988-2005\end{array}$ \\
\hline 04160000 & Mill Creek near Abbottsford, Mich. & 43.04503 & 82.61381 & 184 & 8.5 & 0.04620 & August & 18 & $1947-1964$ \\
\hline 04160050 & Black River near Port Huron, Mich. & 42.99003 & 82.53770 & 683 & 19.0 & 0.02783 & September & 11 & 1933-1943 \\
\hline 04160570 & $\begin{array}{l}\text { North Branch Belle River at Imlay City, } \\
\text { Mich. }\end{array}$ & 43.03031 & 83.06716 & 16.1 & 2.3 & 0.14286 & August & 36 & 1966-2001 \\
\hline 04160600 & Belle River at Memphis, Mich. & 42.90086 & 82.76909 & 151 & 13.0 & 0.08587 & September & 43 & 1963-2005 \\
\hline 04160800 & Sashabaw Creek near Drayton Plains, Mich. & 42.72003 & 83.35355 & 21.0 & 2.2 & 0.10476 & September & 46 & 1960-2005 \\
\hline 04160900 & Clinton River near Drayton Plains, Mich. & 42.66031 & 83.39022 & 78.5 & 14.0 & 0.17834 & August & 46 & 1960-2005 \\
\hline 04161000 & Clinton River at Auburn Hills, Mich. & 42.63337 & 83.22438 & 123 & 44 & 0.35685 & August & 34 & $\begin{array}{c}\text { 1935-1938, } \\
1940, \\
1957-1982, \\
2001-2002, \\
2004-2005\end{array}$ \\
\hline 04161100 & Galloway Creek near Auburn Heights, Mich. & 42.66725 & 83.20049 & 17.4 & 1.6 & 0.09195 & August & 32 & 1960-1991 \\
\hline 04161500 & Paint Creek near Lake Orion, Mich. & 42.76753 & 83.21994 & 39.8 & 9.0 & 0.22613 & August & 23 & $\begin{array}{r}\text { 1956-1975, } \\
\text { 1989-1991 }\end{array}$ \\
\hline 04161540 & Paint Creek at Rochester, Mich. & 42.68837 & 83.14299 & 71.8 & 21.0 & 0.29248 & August & 46 & 1960-2005 \\
\hline 04161580 & Stony Creek near Romeo, Mich. & 42.80086 & 83.09021 & 23.8 & 3.9 & 0.16387 & August & 41 & 1965-2005 \\
\hline 04161800 & Stony Creek near Washington, Mich. & 42.71531 & 83.09188 & 69.1 & 13.0 & 0.18813 & August & 48 & 1958-2005 \\
\hline
\end{tabular}


Table 1-1. Flow, yield, and record characteristics for streamflow-gaging stations used in the regression analysis-Continued.

\begin{tabular}{|c|c|c|c|c|c|c|c|c|c|}
\hline $\begin{array}{c}\text { U.S. } \\
\text { Geological } \\
\text { Survey } \\
\text { station } \\
\text { number }\end{array}$ & Station name & $\begin{array}{l}\text { Latitude } \\
\text { (decimal } \\
\text { degrees) }\end{array}$ & $\begin{array}{l}\text { Longitude } \\
\text { (decimal } \\
\text { degrees) }\end{array}$ & $\begin{array}{c}\text { Drainage } \\
\text { area } \\
\text { (square } \\
\text { miles) }\end{array}$ & $\begin{array}{l}\text { Minimum } \\
\text { monthly } \\
\text { median flow } \\
\text { (cubic feet } \\
\text { per second) } \\
\left(/ Q_{50}\right)\end{array}$ & $\begin{array}{c}\text { Minimum } \\
\text { monthly median } \\
\text { yield (cubic feet } \\
\text { per second per } \\
\text { square mile) } \\
\left(I Y_{50}\right)\end{array}$ & $\begin{array}{l}\text { Month of } \\
\text { minimum } \\
\text { flow }\end{array}$ & $\begin{array}{l}\text { Years } \\
\text { of } \\
\text { record }\end{array}$ & $\begin{array}{c}\text { Water years } \\
\text { included in } \\
\text { analyses }\end{array}$ \\
\hline 04163400 & Plum Brook at Utica, Mich. & 42.60142 & 83.07409 & 16.6 & 2.8 & 0.16867 & August & 40 & $\begin{array}{l}1965-1998 \\
2000-2005\end{array}$ \\
\hline 04163500 & Plum Brook near Utica, Mich. & 42.58365 & 83.03048 & 23.8 & 0.7 & 0.02857 & July & 13 & 1954-1966 \\
\hline 04164100 & East Pond Creek at Romeo, Mich. & 42.82253 & 83.02021 & 20.8 & 4.9 & 0.23558 & August & 47 & 1959-2005 \\
\hline 04164300 & East Branch Coon Creek at Armada, Mich. & 42.84586 & 82.88493 & 12.8 & 0.2 & 0.01641 & August & 47 & 1959-2005 \\
\hline 04164500 & $\begin{array}{l}\text { North Branch Clinton R near Mount } \\
\text { Clemens, Mich. }\end{array}$ & 42.62920 & 82.88881 & 198 & 12.0 & 0.06073 & September & 59 & 1947-2005 \\
\hline 04164800 & $\begin{array}{l}\text { Middle Branch Clinton River at Macomb, } \\
\text { Mich. }\end{array}$ & 42.70642 & 82.95909 & 41.2 & 3.5 & 0.08495 & September & 19 & $\begin{array}{r}\text { 1963-1968, } \\
1970-1982\end{array}$ \\
\hline 04166000 & River Rouge at Birmingham, Mich. & 42.54587 & 83.22354 & 36.7 & 6.2 & 0.16894 & September & 56 & 1950-2005 \\
\hline 04166200 & Evans Ditch at Southfield, Mich. & 42.45781 & 83.26743 & 10.2 & 1.9 & 0.18627 & September & 48 & 1958-2005 \\
\hline 04166300 & Upper River Rouge at Farmington, Mich. & 42.46448 & 83.36966 & 17.6 & 4.1 & 0.23295 & September & 48 & 1958-2005 \\
\hline 04169500 & Huron River at Commerce, Mich. & 42.59031 & 83.48466 & 49.9 & 12.0 & 0.24048 & August & 30 & 1946-1975 \\
\hline 04170000 & Huron River at Milford, Mich. & 42.57892 & 83.62661 & 139 & 46.0 & 0.33141 & August & 57 & 1949-2005 \\
\hline 04170500 & Huron River near New Hudson, Mich. & 42.51253 & 83.67633 & 155 & 54.0 & 0.34771 & August & 57 & 1949-2005 \\
\hline 04171500 & South Ore Creek near Brighton, Mich. & 42.49781 & 83.80244 & 33.3 & 7.4 & 0.22222 & September & 18 & $1951-1968$ \\
\hline 04172000 & Huron River near Hamburg, Mich. & 42.46531 & 83.79994 & 320 & 103 & 0.32177 & September & 54 & 1952-2005 \\
\hline 04173000 & Huron River near Dexter, Mich. & 42.38615 & 83.91106 & 538 & 120 & 0.22326 & August & 29 & $\begin{array}{r}1946-1972, \\
1976-1977\end{array}$ \\
\hline 04173500 & Mill Creek near Dexter, Mich. & 42.30004 & 83.89856 & 131 & 23.0 & 0.17598 & September & 42 & $\begin{array}{r}1952-1982, \\
1995-2005\end{array}$ \\
\hline 04174500 & Huron River at Ann Arbor, Mich. & 42.28615 & 83.73327 & 747 & 147 & 0.19684 & August & 91 & 1915-2005 \\
\hline 04174800 & Huron River at Ypsilanti, Mich. & 42.24921 & 83.61244 & 817 & 235 & 0.28750 & August & 16 & $\begin{array}{r}1974-1984, \\
1990-1994\end{array}$ \\
\hline 04175600 & River Raisin near Manchester, Mich. & 42.16809 & 84.07606 & 128 & 32.0 & 0.25059 & August & 33 & $\begin{array}{l}\text { 1970-1981, } \\
1985-2005\end{array}$ \\
\hline
\end{tabular}


Table 1-1. Flow, yield, and record characteristics for streamflow-gaging stations used in the regression analysis-Continued.

[A water year is the 12-month period from October 1 to September 30. The water year is designated by the calendar year in which it ends]

\begin{tabular}{|c|c|c|c|c|c|c|c|c|c|}
\hline $\begin{array}{c}\text { U.S. } \\
\text { Geological } \\
\text { Survey } \\
\text { station } \\
\text { number }\end{array}$ & Station name & $\begin{array}{l}\text { Latitude } \\
\text { (decimal } \\
\text { degrees) }\end{array}$ & $\begin{array}{c}\text { Longitude } \\
\text { (decimal } \\
\text { degrees) }\end{array}$ & $\begin{array}{l}\text { Drainage } \\
\text { area } \\
\text { (square } \\
\text { miles) }\end{array}$ & $\begin{array}{c}\text { Minimum } \\
\text { monthly } \\
\text { median flow } \\
\text { (cubic feet } \\
\text { per second) } \\
\left(I Q_{50}\right)\end{array}$ & $\begin{array}{c}\text { Minimum } \\
\text { monthly median } \\
\text { yield (cubic feet } \\
\text { per second per } \\
\text { square mile) } \\
\left(I Y_{50}\right)\end{array}$ & $\begin{array}{l}\text { Month of } \\
\text { minimum } \\
\text { flow }\end{array}$ & $\begin{array}{c}\text { Years } \\
\text { of } \\
\text { record }\end{array}$ & $\begin{array}{c}\text { Water years } \\
\text { included in } \\
\text { analyses }\end{array}$ \\
\hline 04175700 & River Raisin near Tecumseh, Mich. & 41.94310 & 83.94578 & 266 & 62.5 & 0.23532 & August & 24 & $1957-1980$ \\
\hline 04176000 & River Raisin near Adrian, Mich. & 41.90421 & 83.98050 & 460 & 98.5 & 0.21422 & September & 46 & $\begin{array}{r}\text { 1954-1978, } \\
1985-2005\end{array}$ \\
\hline 04176605 & Otter Creek at Lasalle, Mich. & 41.86699 & 83.45354 & 63.7 & 1.7 & 0.02669 & September & 18 & 1988-2005 \\
\hline 04184500 & Bean Creek at Powers, Ohio & 41.67755 & 84.23217 & 205 & 19.0 & 0.09255 & September & 65 & 1941-2005 \\
\hline
\end{tabular}


Table 1-2. Values of selected explanatory variables used in the development of the regression equation for estimating the index flow.

\begin{tabular}{|c|c|c|c|c|c|c|c|c|}
\hline $\begin{array}{c}\text { U.S. } \\
\text { Geological } \\
\text { Survey } \\
\text { station } \\
\text { number }\end{array}$ & $\begin{array}{l}\text { Drainage } \\
\text { area } \\
\text { (square } \\
\text { miles) }\end{array}$ & $\begin{array}{l}\text { Percent of } \\
\text { basin with low } \\
\text { ground-water } \\
\text { transmissivity } \\
\text { (L_Trans) }\end{array}$ & $\begin{array}{l}\text { Percent of } \\
\text { basin with } \\
\text { high ground- } \\
\text { water } \\
\text { transmissivity } \\
\text { (H_Trans) }\end{array}$ & $\begin{array}{l}\text { Percent of } \\
\text { basin with } \\
\text { forest cover } \\
\text { (Forest) }\end{array}$ & $\begin{array}{c}\text { Normal } \\
\text { annual } \\
\text { precipitation } \\
\text { for 1971-2000 } \\
\text { (inches) } \\
\text { (Precip) }\end{array}$ & $\begin{array}{l}\text { Percent of } \\
\text { basin with A } \\
\text { hydrologic } \\
\text { soil group } \\
\text { (A_Soils) }\end{array}$ & $\begin{array}{l}\text { Percent of } \\
\text { basin with D } \\
\text { hydrologic } \\
\text { soil group } \\
\text { (D_Soils) }\end{array}$ & $\begin{array}{c}\text { Michigan } \\
\text { hydrologic } \\
\text { subregion }\end{array}$ \\
\hline 04001000 & 13.2 & 98.0 & 0.0 & 91.4 & 31.0 & 0.0 & 0.0 & 1 \\
\hline 04031500 & 172 & .0 & 9.7 & 86.6 & 33.8 & .0 & 10.0 & 1 \\
\hline 04032000 & 264 & 0.8 & 11.3 & 90.3 & 34.2 & .0 & 5.0 & 1 \\
\hline 04033000 & 162 & .0 & 21.0 & 86.6 & 31.7 & 1.0 & 62.0 & 1 \\
\hline 04035000 & 273 & 27.0 & 23.9 & 89.0 & 32.2 & 14.0 & 47.0 & 1 \\
\hline 04043050 & 29.6 & 36.2 & 3.6 & 59.5 & 31.4 & 19.0 & 13.0 & 1 \\
\hline 04045500 & 757 & 55.0 & 30.9 & 79.0 & 31.2 & 32.0 & 50.0 & 1 \\
\hline 04046000 & 33.5 & 27.7 & .0 & 75.4 & 30.7 & 32.0 & 30.0 & 1 \\
\hline 04049500 & 420 & 31.5 & 48.9 & 68.4 & 30.5 & 54.0 & 14.0 & 1 \\
\hline 04055000 & 716 & 46.6 & 36.4 & 60.8 & 30.5 & 62.0 & 12.0 & 1 \\
\hline 04056000 & 326 & 60.3 & 29.9 & 77.9 & 31.6 & 72.0 & 5.0 & 1 \\
\hline 04056500 & 1,130 & 53.4 & 32.1 & 66.4 & 30.8 & 32.0 & 49.0 & 1 \\
\hline 04057510 & 184 & 12.7 & 85.5 & 79.8 & 31.4 & 45.0 & 35.0 & 1 \\
\hline 04060993 & 378 & .0 & 29.7 & 72.6 & 31.2 & 3.0 & 13.0 & 1 \\
\hline 04061500 & 600 & 1.8 & 19.7 & 84.5 & 31.5 & 3.0 & 78.0 & 1 \\
\hline 04062200 & 132 & 97.9 & .0 & 84.9 & 33.1 & 1.0 & 42.0 & 1 \\
\hline 04096015 & 80.8 & 15.4 & 8.3 & 17.0 & 37.6 & 11.0 & 11.0 & 2 \\
\hline 04096405 & 201 & .0 & 69.6 & 18.5 & 35.3 & 8.0 & 14.0 & 2 \\
\hline 04096515 & 48.7 & .0 & 32.5 & 15.4 & 35.7 & 11.0 & 11.0 & 2 \\
\hline 04096600 & 286 & .0 & 57.2 & 16.0 & 36.0 & 4.0 & 14.0 & 2 \\
\hline 04096900 & 162 & .0 & 96.7 & 24.5 & 36.1 & 7.0 & 21.0 & 2 \\
\hline 04097170 & 68.2 & .0 & 86.8 & 19.0 & 37.0 & 1.0 & 15.0 & 2 \\
\hline 04097540 & 107 & .0 & 80.3 & 18.5 & 36.5 & 10.0 & 15.0 & 2 \\
\hline 04099000 & 1,880 & .0 & 76.0 & 18.2 & 36.4 & 9.0 & 14.0 & 2 \\
\hline 04101500 & 3,670 & .0 & 77.7 & 18.3 & 36.9 & 9.0 & 14.0 & 2 \\
\hline 04101800 & 252 & .0 & 94.5 & 20.8 & 37.8 & 23.0 & 13.0 & 2 \\
\hline
\end{tabular}


Table 1-2. Values of selected explanatory variables used in the development of the regression equation for estimating the index flow-Continued.

\begin{tabular}{|c|c|c|c|c|c|c|c|c|}
\hline $\begin{array}{c}\text { U.S. } \\
\text { Geological } \\
\text { Survey } \\
\text { station } \\
\text { number }\end{array}$ & $\begin{array}{l}\text { Drainage } \\
\text { area } \\
\text { (square } \\
\text { miles) }\end{array}$ & $\begin{array}{c}\text { Percent of } \\
\text { basin with low } \\
\text { ground-water } \\
\text { transmissivity } \\
\text { (L_Trans) }\end{array}$ & $\begin{array}{c}\text { Percent of } \\
\text { basin with } \\
\text { high ground- } \\
\text { water } \\
\text { transmissivity } \\
\text { (H_Trans) }\end{array}$ & $\begin{array}{c}\text { Percent of } \\
\text { basin with } \\
\text { forest cover } \\
\text { (Forest) }\end{array}$ & 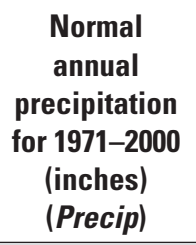 & $\begin{array}{l}\text { Percent of } \\
\text { basin with A } \\
\text { hydrologic } \\
\text { soil group } \\
\text { (A_Soils) }\end{array}$ & $\begin{array}{l}\text { Percent of } \\
\text { basin with D } \\
\text { hydrologic } \\
\text { soil group } \\
\text { (D_Soils) }\end{array}$ & $\begin{array}{c}\text { Michigan } \\
\text { hydrologic } \\
\text { subregion }\end{array}$ \\
\hline 04102500 & 390 & 1.9 & 71.5 & 25.8 & 37.7 & 36.0 & 16.0 & 2 \\
\hline 04102700 & 83.5 & 1.1 & 36.1 & 32.5 & 37.7 & 23.0 & 26.0 & 2 \\
\hline 04103010 & 270 & .0 & 54.7 & 16.0 & 34.9 & 6.0 & 11.0 & 2 \\
\hline 04104945 & 48.3 & .0 & 55.4 & 24.9 & 35.5 & 12.0 & 18.0 & 2 \\
\hline 04105000 & 274 & .0 & 44.7 & 22.4 & 34.8 & 12.0 & 17.0 & 2 \\
\hline 04105700 & 36.8 & .0 & 99.1 & 28.2 & 36.6 & 4.0 & 16.0 & 2 \\
\hline 04108600 & 65.1 & .0 & 48.4 & 21.1 & 36.7 & 23.0 & 13.0 & 2 \\
\hline 04108801 & 66.9 & 1.7 & 25.0 & 8.3 & 36.4 & 11.0 & 5.0 & 2 \\
\hline 04110000 & 47.3 & .0 & 39.5 & 19.6 & 32.7 & 25.0 & 18.0 & 2 \\
\hline 04111500 & 16.3 & .0 & 4.4 & 15.1 & 32.6 & 14.0 & 13.0 & 2 \\
\hline 04112000 & 10.4 & .0 & .0 & 13.6 & 32.5 & 2.0 & 8.0 & 2 \\
\hline 04112500 & 344 & .0 & 13.7 & 14.2 & 32.6 & 11.0 & 14.0 & 2 \\
\hline 04114498 & 284 & .0 & 28.9 & 14.8 & 32.4 & 9.0 & 18.0 & 2 \\
\hline 04115000 & 420 & 29.3 & 20.1 & 10.7 & 32.4 & 5.0 & 15.0 & 2 \\
\hline 04116500 & 516 & .0 & 79.0 & 26.7 & 34.0 & 45.0 & 19.0 & 2 \\
\hline 04117000 & 7.8 & .0 & 30.8 & 21.9 & 35.3 & 4.0 & 14.0 & 2 \\
\hline 04117500 & 410 & .0 & 30.3 & 18.4 & 34.9 & 5.0 & 12.0 & 2 \\
\hline 04118000 & 795 & .0 & 31.3 & 21.8 & 35.2 & 11.0 & 11.0 & 2 \\
\hline 04118500 & 257 & .0 & 46.6 & 29.8 & 34.5 & 36.0 & 12.0 & 2 \\
\hline 04121000 & 352 & .0 & 85.2 & 63.1 & 30.7 & 57.0 & 16.0 & 3 \\
\hline 04121300 & 239 & 3.1 & 77.2 & 53.0 & 32.1 & 62.0 & .0 & 3 \\
\hline 04121900 & 136 & .0 & 96.0 & 41.4 & 33.4 & 60.0 & 15.0 & 3 \\
\hline 04122100 & 16.7 & 70.6 & 25.8 & 43.5 & 34.0 & 32.0 & 15.0 & 3 \\
\hline 04122200 & 404 & .0 & 81.7 & 57.9 & 34.0 & 62.0 & 15.0 & 3 \\
\hline 04122500 & 689 & .0 & 91.3 & 74.7 & 33.8 & 70.0 & 16.0 & 3 \\
\hline 04123000 & 115 & .0 & 91.1 & 79.7 & 33.5 & 64.0 & 21.0 & 3 \\
\hline 04123500 & 132 & .0 & 100.0 & 73.0 & 32.2 & 92.0 & 5.0 & 3 \\
\hline 04124000 & 865 & .0 & 94.4 & 76.3 & 31.9 & 80.0 & 12.0 & 3 \\
\hline 04124500 & 58.9 & .0 & 31.2 & 40.1 & 32.6 & 54.0 & 18.0 & 3 \\
\hline 04125000 & 130 & .0 & 54.5 & 51.7 & 32.7 & 61.0 & 11.0 & 3 \\
\hline 04125500 & 254 & .0 & 72.1 & 61.6 & 32.9 & 63.0 & 9.0 & 3 \\
\hline 04126200 & 185 & .0 & 99.3 & 83.3 & 33.5 & 84.0 & 10.0 & 3 \\
\hline 04127918 & 202 & 44.5 & 26.6 & 71.3 & 32.1 & 30.0 & 43.0 & 1 \\
\hline 04127997 & 181 & .0 & 98.6 & 69.2 & 31.4 & 77.0 & 13.0 & 4 \\
\hline 04128990 & 57.7 & .0 & 90.6 & 64.4 & 30.9 & 66.0 & 22.0 & 4 \\
\hline
\end{tabular}


Table 1-2. Values of selected explanatory variables used in the development of the regression equation for estimating the index flow-Continued.

\begin{tabular}{|c|c|c|c|c|c|c|c|c|}
\hline $\begin{array}{c}\text { U.S. } \\
\text { Geological } \\
\text { Survey } \\
\text { station } \\
\text { number }\end{array}$ & $\begin{array}{l}\text { Drainage } \\
\text { area } \\
\text { (square } \\
\text { miles) }\end{array}$ & $\begin{array}{c}\text { Percent of } \\
\text { basin with low } \\
\text { ground-water } \\
\text { transmissivity } \\
\text { (L_Trans) }\end{array}$ & $\begin{array}{c}\text { Percent of } \\
\text { basin with } \\
\text { high ground- } \\
\text { water } \\
\text { transmissivity } \\
\text { (H_Trans) }\end{array}$ & $\begin{array}{c}\text { Percent of } \\
\text { basin with } \\
\text { forest cover } \\
\text { (Forest) }\end{array}$ & $\begin{array}{c}\text { Normal } \\
\text { annual } \\
\text { precipitation } \\
\text { for 1971-2000 } \\
\text { (inches) } \\
\text { (Precip) }\end{array}$ & $\begin{array}{c}\text { Percent of } \\
\text { basin with A } \\
\text { hydrologic } \\
\text { soil group } \\
\text { (A_Soils) }\end{array}$ & $\begin{array}{c}\text { Percent of } \\
\text { basin with D } \\
\text { hydrologic } \\
\text { soil group } \\
\text { (D_Soils) }\end{array}$ & $\begin{array}{l}\text { Michigan } \\
\text { hydrologic } \\
\text { subregion }\end{array}$ \\
\hline 04129000 & 586 & 1.1 & 55.4 & 71.4 & 28.5 & 38.0 & 24.0 & 4 \\
\hline 04135000 & 96.6 & .0 & 97.8 & 69.4 & 31.8 & 88.0 & 6.0 & 4 \\
\hline 04135500 & 71.2 & .0 & 100.0 & 70.9 & 31.2 & 85.0 & 8.0 & 4 \\
\hline 04135600 & 391 & .0 & 97.8 & 81.1 & 30.2 & 76.0 & 15.0 & 4 \\
\hline 04135700 & 1,360 & .5 & 94.7 & 80.1 & 30.2 & 81.0 & 11.0 & 4 \\
\hline 04138500 & 29.8 & .0 & 48.7 & 58.1 & 29.6 & 54.0 & 14.0 & 5 \\
\hline 04139000 & 57.4 & .0 & 53.5 & 58.2 & 29.5 & 47.0 & 19.0 & 5 \\
\hline 04139500 & 21.0 & .0 & 46.7 & 45.7 & 29.8 & 41.0 & 15.0 & 5 \\
\hline 04140000 & 116 & .0 & 53.4 & 55.8 & 29.6 & 44.0 & 20.0 & 5 \\
\hline 04140500 & 1.1 & .0 & .0 & 13.1 & 29.9 & 5.0 & 8.0 & 5 \\
\hline 04141000 & 65.4 & 5.0 & 50.8 & 50.8 & 30.0 & 52.0 & 13.0 & 5 \\
\hline 04141500 & 333 & 3.6 & 36.2 & 56.2 & 30.0 & 43.0 & 20.0 & 5 \\
\hline 04146063 & 526 & 14.9 & 33.0 & 20.1 & 31.3 & 9.0 & 17.0 & 5 \\
\hline 04147500 & 34.8 & 12.3 & 28.4 & 23.9 & 31.5 & 12.0 & 12.0 & 5 \\
\hline 04147990 & 99.7 & 5.6 & 32.9 & 19.3 & 31.5 & 11.0 & 16.0 & 5 \\
\hline 04148140 & 6.9 & 67.2 & .0 & 6.5 & 31.6 & 2.0 & 4.0 & 5 \\
\hline 04148160 & 12.1 & .0 & 52.9 & 21.7 & 31.5 & 17.0 & 26.0 & 5 \\
\hline 04148200 & 114 & 6.1 & 13.1 & 14.7 & 31.6 & 4.0 & 14.0 & 5 \\
\hline 04148300 & 54.4 & .5 & 26.9 & 18.1 & 31.5 & 11.0 & 14.0 & 5 \\
\hline 04148440 & 960 & 15.3 & 27.5 & 17.7 & 31.5 & 9.0 & 15.0 & 5 \\
\hline 04148500 & 239 & .0 & 26.6 & 10.1 & 31.0 & 11.0 & 11.0 & 5 \\
\hline 04150000 & 363 & 6.2 & 31.1 & 12.4 & 31.1 & 12.0 & 16.0 & 5 \\
\hline 04150500 & 842 & 9.8 & 25.9 & 20.7 & 31.0 & 14.0 & 18.0 & 5 \\
\hline 04151500 & 152 & 1.3 & 64.3 & 42.1 & 31.5 & 46.0 & 18.0 & 5 \\
\hline 04152238 & 145 & 39.3 & 4.2 & 19.6 & 31.7 & 6.0 & 14.0 & 5 \\
\hline
\end{tabular}


Table 1 -2. Values of selected explanatory variables used in the development of the regression equation for estimating the index flow-Continued.

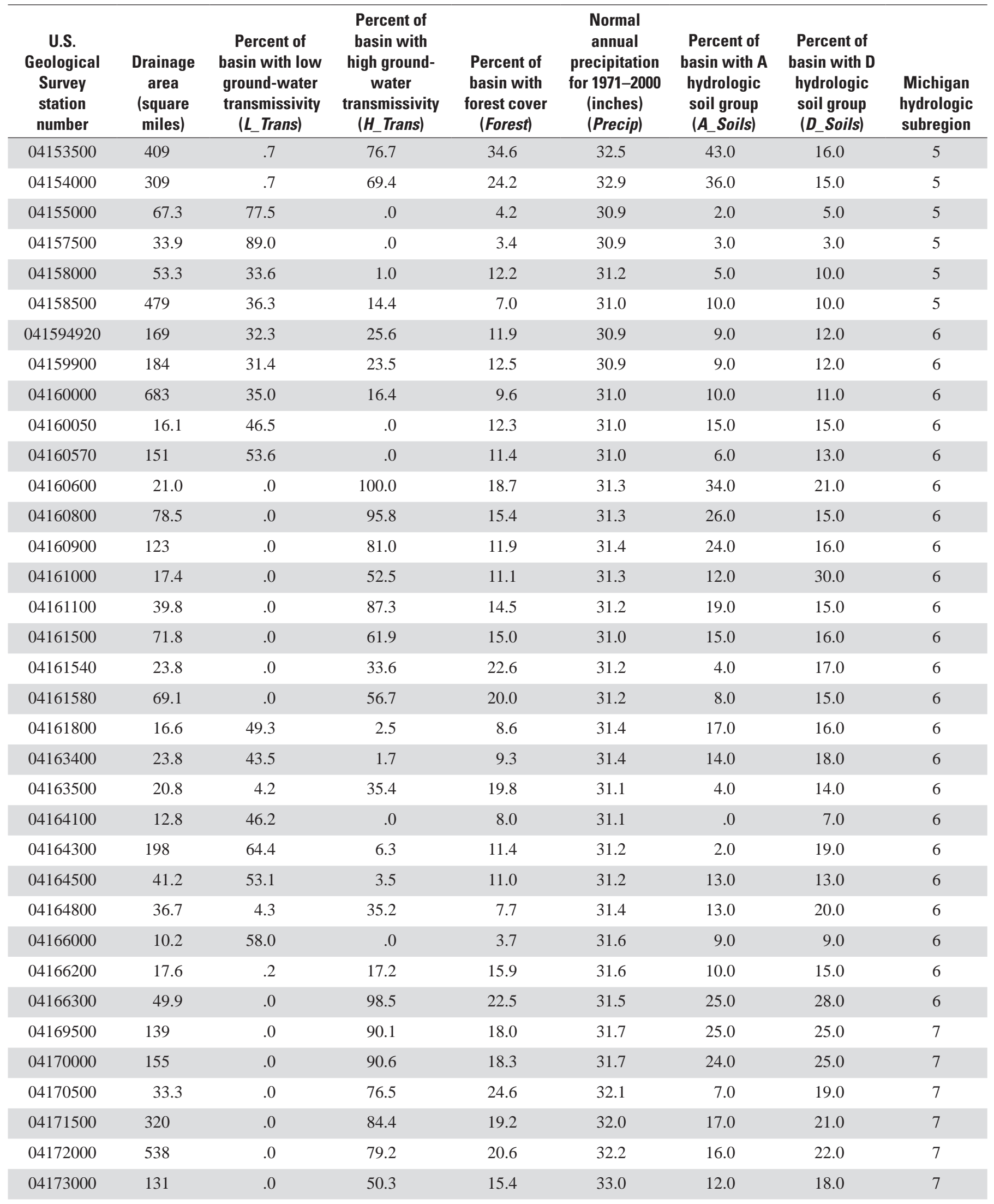


Table 1-2. Values of selected explanatory variables used in the development of the regression equation for estimating the index flow-Continued.

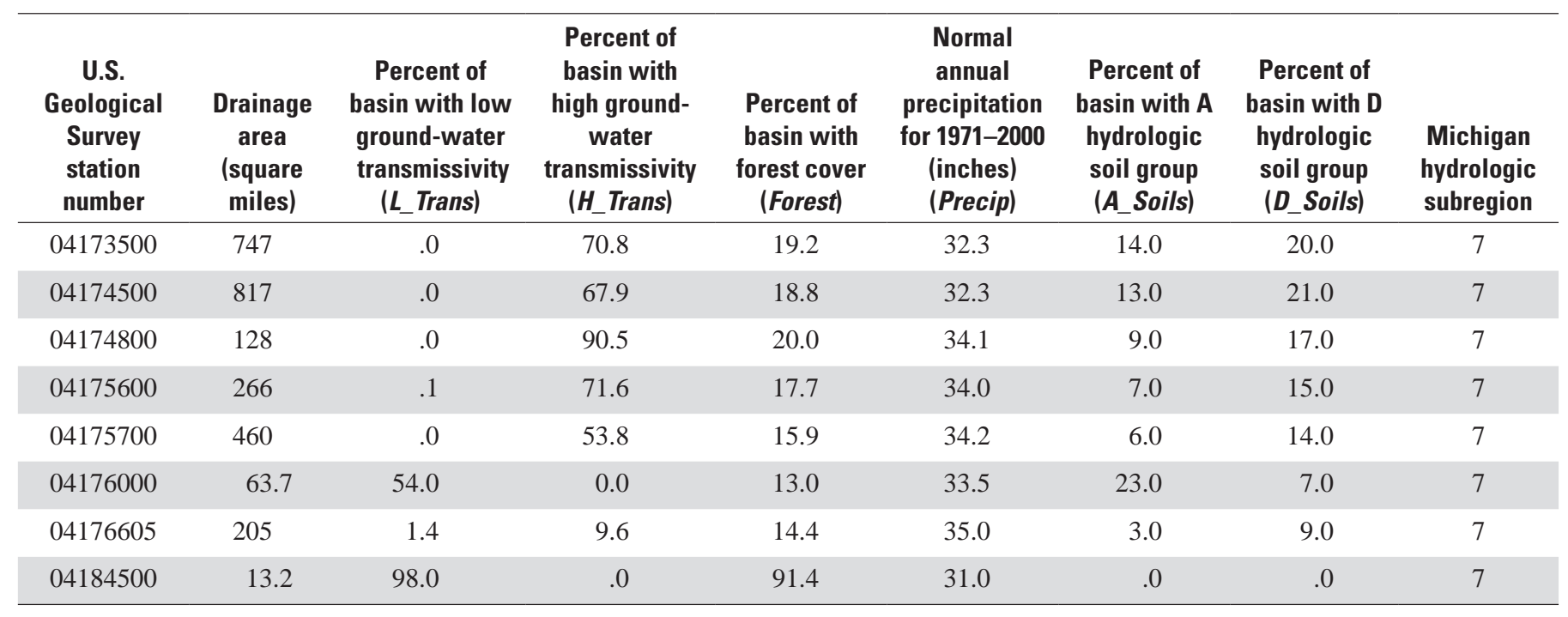


Table 1-3. Cross-tabulation of cell counts and percentages for Michigan Resource Information System (MIRIS) 1978 land use-land cover and hydrologic soil groups in Michigan'.

\begin{tabular}{|c|c|c|c|c|c|c|c|}
\hline \multirow[b]{2}{*}{ Land use-land cover } & \multicolumn{4}{|c|}{ Hydrologic soil group } & \multirow{2}{*}{$\begin{array}{l}\text { Outside of } \\
\text { Michigan }^{2}\end{array}$} & \multirow[b]{2}{*}{ Percent } & \multirow{2}{*}{$\begin{array}{l}\text { Adjusted } \\
\text { percent }^{3}\end{array}$} \\
\hline & A & B & C & D & & & \\
\hline Urban & $4,343,953$ & $4,432,438$ & $1,137,269$ & 555,570 & 14,563 & 1.6 & 6.3 \\
\hline Agriculture & $8,163,149$ & $26,685,700$ & $1,2077,467$ & $2,000,247$ & 2,392 & 7.4 & 29.3 \\
\hline Range land & $5,292,626$ & $4,255,525$ & $1,338,514$ & 2,544,935 & 5,416 & 2.0 & 8.0 \\
\hline Forest & $31,740,852$ & $19,970,933$ & 6,257,886 & 2,3151,323 & 453,893 & 12.3 & 48.8 \\
\hline Water & 148,888 & 193,023 & 24,015 & 3,391,954 & 42,373 & 0.6 & 2.3 \\
\hline Wetland & $1,457,774$ & 873,403 & 314,675 & $5,950,392$ & 59,920 & 1.3 & 5.2 \\
\hline Barren & 105,535 & 9,180 & 9,802 & 49,231 & 43,448 & 0.0 & 0.1 \\
\hline Outside of Michigan & 28,474 & 7,383 & 1,510 & 693,402 & 496,646,760 & 74.9 & -- \\
\hline Percent & 7.7 & 8.5 & 3.2 & 5.8 & 74.8 & 100 & 100 \\
\hline Adjusted percent & 30.7 & 33.7 & 12.7 & 22.9 & -- & 100 & 100 \\
\hline
\end{tabular}

${ }^{1}$ The Michigan Resource Information System represents the 1978 land use-land cover and hydrologic soil groups in Michigan as a rectangular grid of integers that contain 26,319 rows and 25,247 columns. Each grid is identically referenced geographically. Each cell in the grid represents a land area of 30 meters square (900 square meters). Numeric codes for the land use-land cover grid are as follows: (1) urban or built-up land, (2) agricultural land, (3) rangeland, (4) forest land, which included Level II classification of deciduous, evergreen, and mixed forest lands, (5) water, (6) wetland, and (7) barren land. For hydrologic soil groups numeric codes are as follows: (1) group A soils, (2) group B soils, (3) group C soils, and (4) group D soils. For both coverages, the code -9999 signifies no data or inapplicable, which occurs over extensive areas of adjacent states, the Province of Ontario, Canada, and the Great Lakes.

2 "Outside of Michigan" refers to land areas of adjacent states and the Province of Ontario, Canada, and water areas over the Great Lakes, both within and outside of Michigan.

${ }^{3}$ Adjusted percentage accounts only for the land areas within Michigan. 


